University of Rhode Island

DigitalCommons@URI

Open Access Master's Theses

1970

\title{
Coastal Environmental Management Policy: West Narragansett Bay, Rhode Island
}

David S. Rogers

University of Rhode Island

Follow this and additional works at: https://digitalcommons.uri.edu/theses

\section{Recommended Citation}

Rogers, David S., "Coastal Environmental Management Policy: West Narragansett Bay, Rhode Island" (1970). Open Access Master's Theses. Paper 494.

https://digitalcommons.uri.edu/theses/494

This Thesis is brought to you for free and open access by DigitalCommons@URI. It has been accepted for inclusion in Open Access Master's Theses by an authorized administrator of DigitalCommons@URI. For more information, please contact digitalcommons-group@uri.edu. 
COASTAL ENVIROMVENTAL MANAGENFNT POLICY:

WEST NARRAGANSETT BAY, RHODE ISIAND

$\mathrm{BY}$.

DAVID H. ROGFIS;

A THESIS SUBMITIED IN PARTIAL FUSPIILMENT OF THE REQUIRFMENTS FOR THE DEGREE OT

MASTER OF COMMUNTIY PTANNITG 
TITLE ABSTRACT

COASTAL ENVIRONRENTAL MANAGELWIT POLICY 


\section{ALSTR:CL.}

The runicipalivios of Cranston, harbick, East Geenwich, ana North kingstoin, Rhode Isiand, togetlex control seventy miles of shore-

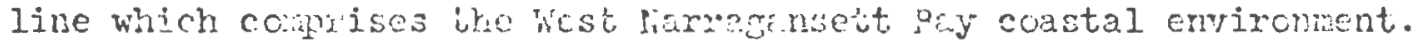
These cities can tonn inciecsed in porulation an averâe of thirtythree percent beiween ninetetu fifity and nincteen sixty compured to a statewide increase of twelve percent aluing the saric period. Much of the resultant development pressure has been focused on the constal iends of eaci torn wherc such locetion orjers a scenic, recreation and industrial potential. The study concentrates cil this coastal developmat; specifically, how the coastal resources are used and the mannex in which the four nunicipalities concoive ano formate their public policy regulating this development. Sach tom arif cjty opereting under differing goverimental structures hes reacted unicilely tomand the regulation of the shoreltre. The cilies facing difizcult problems of high-density developrent in coastal areas have directed their policy toward cnis quite different than the less developed towns. The stuty area in its geographical and eovernmortal diversity ropesents onefourti of the State's sait water coastal resources and thus provides a significunt sample of the types of problems ond solutions confronting other Rhode Island corminities.

The study seeks to accorplich tho following objectives: (a) to deterine how coatal lano use pattens have croived histerically; (u) to detcrmine what loce]. policiss ore Eresently cuployed which direst

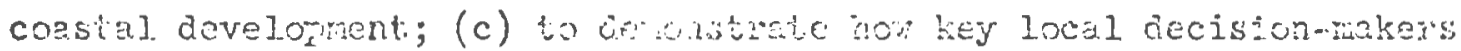

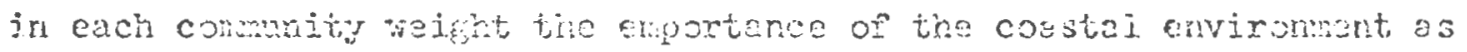


of theix coastal zore manachent polic ics, determincd by objective (i) above; and (d) to dencnstrate hod decisions arfecting the coastal environment have hech made on kout sim unicipal. jusurs gril on area issues were runiciptities, state and federa? agencjes and private interest gronis have interactad.

Objective $A$ or the sturly is accomlishad by iracing, throdgh the use of maps and historical dccuments, the development of the seventy miles of coastline within the study area. Orjective $B$ is accoulished through the aralysjs of existing puldic docunants such as the comprehensive plar to dotemine how coasial envijennental resources are reconimended to be allocatea. This procedure is supplemented by personal intcrviess with key muicipal offjcials functioning in develoment

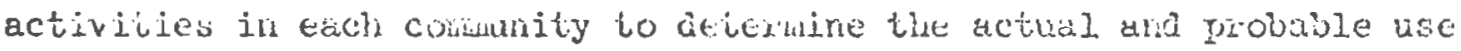
of the coustal enviromment. Objective $C$ is accominghed through the use of personal and mailed intervier questions to elscted and auministrative poljcy makers. These decision-makers are determined on the basis of both their elected or administratjue position vithin the cominity as well as their reputation as key decision-mikers in past decisions effecting the ccostal environment in thej.r comanity. Oujective is is accornlished by analyzing the structure of ezch local governinent, by the vase of persoul and mailed interview questions, and throuk the presentation of case stubies illustruting the resolution of fast local. anå regional envircnrentel issues.

Narragancti Bay is the stete's pritay nawual resource, yet it is vicwed by local docisicn-maks only in tems of local envircuratal

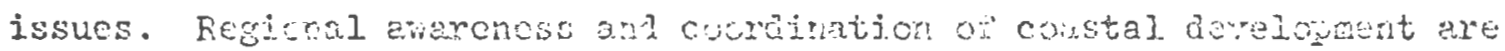


limited. The effectiveness of planning as a mechanism for stimulating coastal resource management is related to the pace of urbanization and political and professional leadership. The market factor is the primary stimulus for coastal decision-making processes for costal concerus. Ecologic considerations are generally ignored in these processes. With the clear exception of Warwick, study area municipalities have no coastal management policy. 


\section{MASTER OF COIMUNITY PLANNING THESIS \\ $\mathrm{OF}$}

DAVID H. ROGERS

Approved:

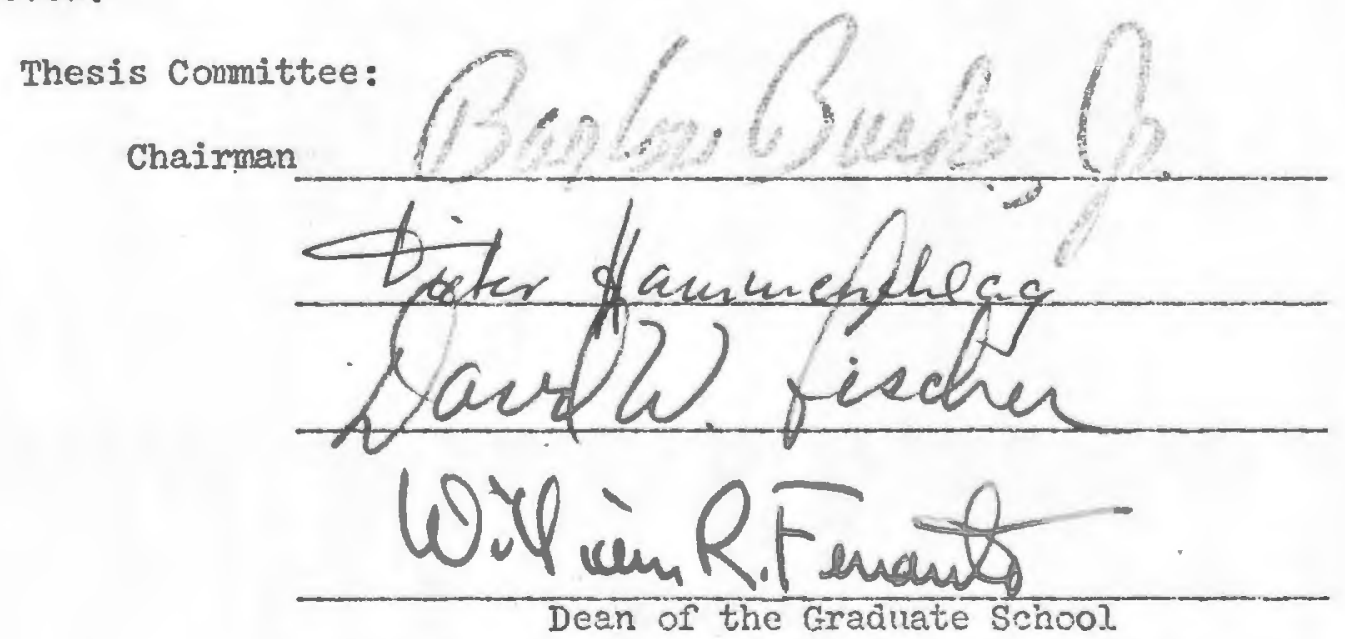

UNIVH'RSTYY OF RHODE ISLAND

1970 


\section{PREFACE}

A prerequisite for a study of this type is cooperation from a great many State and local officials. Without heșitation these busy individusls cooperated fully and exhibited a keen interest in this research topic. While shortcomings of this undertaking are attributable solely to the author, any small measure of success must rest with these Rhode Island citizens.

Special thanks are extended to Dr. David W. Fischer, Professor D. Barlow Burke, Jr., and Professor Dieter Hammerschlag for their insight and critical review of earlier drafts of this text.

The patience, encouragement, and financial support provided by Paul Bruce Dowling of the America the Beautiful Fund of the Natural Area Council, Washington, D.C., and the Agricultural Experiment Station of the University of Rhode Island, Kingston, R.I., is gratefully acknow ledged. 
Introduction ........................ 1 CHAPTER

I Methodology ..................... 5 Formulating the Study Design

II Change and the Coastal Environment. . . . . . . . . I7 Decision-making Coastal Land-Use Change Coastal Environmental Management: Decision-making The Decision Field

Decision-making Factors

III Historical setting. ................. 64 Cranston Warwick East Greenwich North Kingstown

IV Application of the Analytical Framework . . . . . . . 89 Crenston Wartick Fast Greenwich North Kingstown

V Case Study - The Pawtuxet Cove Rederelopment Scheme . . . . 189

VI Regional Considerations ............... 202 VII Conclusions ................... 211 Bibliography . . . . . . . . . . . . 218 Appendix A - Personal Interview Questionnaire. . . . . . . . 222 Appendix B - Mailed Interview Questionnaire. . . . . . . . 233 Appendix C - A Regional Case Study - Conerce Oil Corporation: A New Ref'inery for Jamestown.......... 245 Appenäix D - Rome Point Power Plant - Benefit or Liability . . . 264 
Chart A Jurisdictions and Controls.............61

Chart B. Comparative Development of study Area Municipalities. - 87

Chart C Coastal Land-Use, West Narragansett Bay, Rhode Island - 88

Chart D Governmental Organization - Cranston, Rhode Island. - 92

Chart E Governmental Organization - Warwick, Rhode Island . . 119

Chart F Proposed Governmental Organization - Warwick, Rhode Island. . . . . . . . . . . . 120

Chart G Governmental Organization - East Greenwich, Rhode Island. . . . . . . . . . . . 156

Chart H Governmental Organization - North Kingstown, Rhode Island. . . . . . . . . . . . . 173

Chart I Alternate Procedural Decision-Making Courses Cranston, Rhode Island. ............ 194t

Chart J Alternate Procedural Decision-Making Courses Cranston, Rhode Island. . . . . . . . . . 194

Chart $\mathrm{K}$ Commerce Oil Refinery Case - Participant Positions on Use of Coastal Resources ........... 206

Chart I Sumary of Decision Factors Influencing Study Area Municipalities............ . . 213

Map I study Area. .................. 4 Map II Iand-Use Cranston, Rhode Island. . . . . . . . 71 Map III Land-Use Warwick, Rhode Island .......... 76 Map IV Iand-Use East Greenwich, Rhode Island . . . . . . 81 Map V Land-Use North Kingstown, Rhode Island . . . . . 86 


\section{MiRONUCTJCir}

Narragensett Eay wea ured frem Foint Judith on the Vest to Sekornet

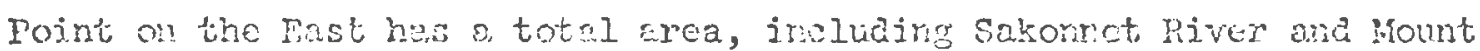
Hope Bur, of $17 h_{\text {t }}$ squan nilcs and a shore line aproximatoly 250 miles long. ${ }^{l}$ The Bay is considered Rhode Islend's primary natural rescures. Historically, urlun develomment patterns have clustered arouna this major geograplic fociure rather than in more inland areas. Fresextly there is increasing poblic denard for access to the coastline for recreational end iesilential purposes. Mationully, while the American pubjic hes more than coubled from $90,000,000$ to over $200,000,000$ in the last rifty years, ocesn frontage has increuscd in value roje than $10,000 \%$ during the same perixa. ${ }^{2}$ To the 1,390,000 persons wo rili live in prowe Is and in the yeax 2000 , the 250 miles of shorcline on Narrainsetc $\mathrm{sey}$ will rejpesent a resource of scenic beanty, recretion, and erploymont votenilal. 3 Beyond this, however, the Bay poses to public officints, to woin this resource is entruted, difficult pioblens in comaluating coaslel develorment patterns arone a variay of usex. In adejtion, jurisuictionol. centrols exist on many corernentel jevels making a unifica aporoch to ranagement of this resource difficurt. Inability to efteatively resulve thene probless is resulting in a change in the Ruy's enrixoments. guality.

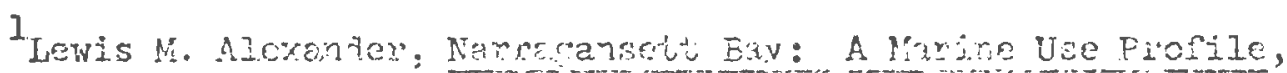

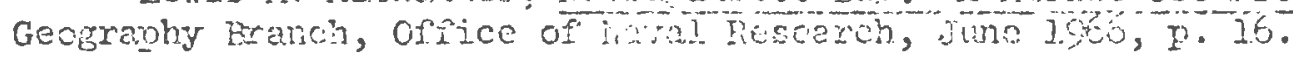

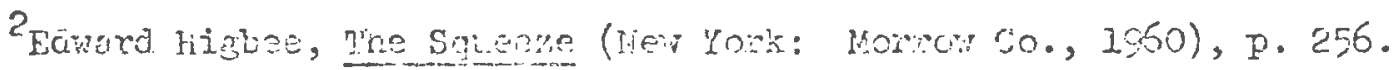

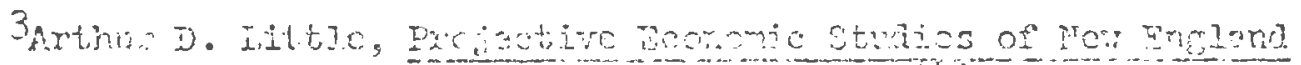

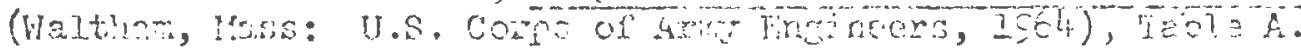


Sore of the rost urgent environnental problems and the most imie-

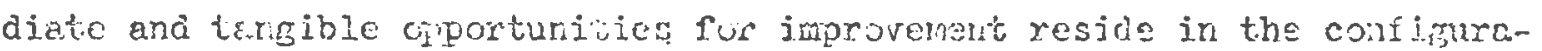
tion of constal land-use potterns. The purpose of this study is to exanine the constal. land-use policies and workings of four local governments in Ringe Is and. These comnuities of Crenston, Wavick, East Greenwich, and North Kingstown comprise the majority of the western side of the Bay and represent differing degrees of urbanizaition. Their actions wij. detomine the form of develoment on coastal lands in the seventy miles of coen frontage comprising the West Nariaganst.t Bay Coastal Environmert.

Map 1 deliniates the study area, stury aren municignlities and identifics areas of significance made reference to in tho text.

The 1559 report of the Rhode Island Natwral. Resources Grow entitled Report on Adninistration of Narracansett Bay, stetes the need for further study into the political structures and manecuent of marine resources in the state. ${ }^{4}$. In line wi.th this nced, this etviy explores how local govemments through their policies and actions jisy a critical role in the evolution of the coastal enviroment.

Chepter I presents methodological cousiderations. These are in the form of a brief review of miblishod studies on the coasiline and general environrantal considerations; and a revies of planuing, public administration, end policy science literature in order to cull useful concerts adoptabie to tinis suby. The chapter also shoris the metrods used in selecting the study area gind interviewari.

${ }^{4}$ Rhole Island liatural Recolitecs Group, Regort on Aciniristration of Narrafianseit Bi.jy, Jariuary 1909. 
Chapter II deals with the nature of change in the coastal environment. An analytical framework is then established for the discussion of factors influencing local coistal policy formulation.

Chapter III describes the study setting, historical evolution of land-use in the four municipalities under study, and the character of present water front land-uses.

Chapter IV then applies interview data for each town to the analytical framework established in Chapter II.

Chapter $\mathrm{V}$ is a case study which shows how the decision-making factors influenced decision-makers and how the firal outcome of a coastal environmental issue has regional implications.

Chapter VI discusses these regional implications in terms of the decision-making factors established in chapter II. This discussion is supportied by additional case studies found in Appendix C and D.

Cbapter VII summarizes the findings for the individual towns and discusses the implications of these findings on the local and regional scale for the future of the coastal environment of Narragansett Bay. 


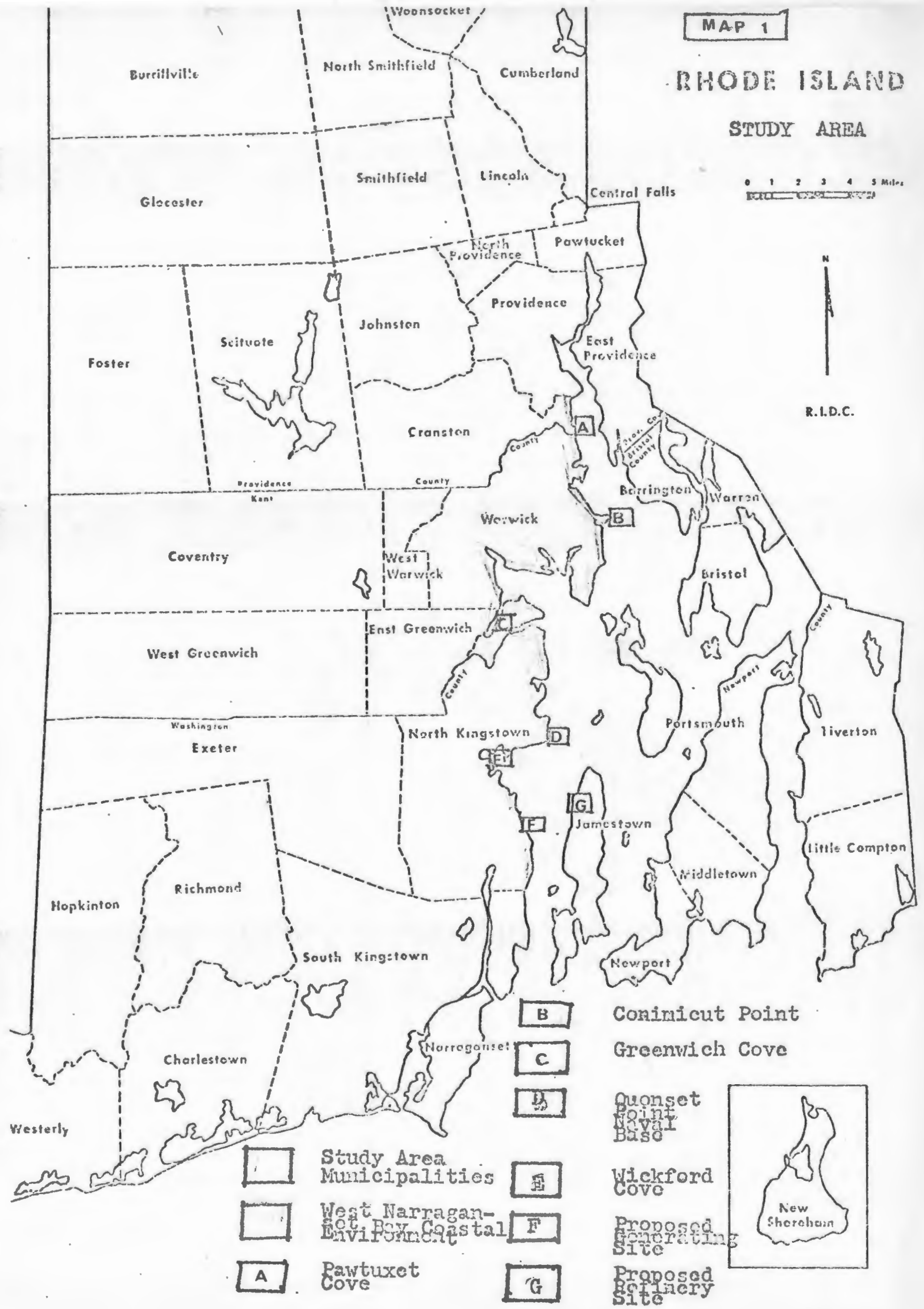


METHODOLOGY 
FORMUIATING THE STUDY DESIGN

I. Review of literature on Coastal Environmental questions

The initial step in formulating a study design was a thorough re-

view of literature dealing with coastal environmental questions in

general and coastal magement policy formulation in particular. The

corstal environment is defined as all land and sea measured one-quarter

mile from the high tide mark. The body of literature found in these

areas is limited. Four general approaches can be defined. These are:

1. Those reports, such as the San Francisco Bay Plan, making specific policy recomendations for coastal areas. I These reports document what should be done and state specific policies.

2. Those books which deal with the impact (especially the negative impact) on coastal ecology of Man's development ectivities. These books arc concemed primarily with how physical design can be integrated with ecologic considerations. The best example of this type of literature is Ian MeHarg's, Design with Nature.?

3. Those reports which deal with the economic inquact of maxine oriented activities for specific coastal areas. Rorholm's study entitled, Economic Inpact of Marineoriented Activities: A Study of the Southern New Frgland Mexire Region is one of many studies typifing this approach.3

4. Those reports which deal with the broad area of marine resource development. Such studies make reference to coastal development in terms of changes in development type over a period of time. The most comprehensive

ISan Francisco Bay Plan, San Francisco Bay Conservation and Developuent Commission, 1969. 1969).

${ }^{2}$ I. McHarg, Design with Nature (New York: Natural History Press,

3N. Rorholm, H. C. Lampe, N. Marshall and J. F. Farrell, Economic Impact of Marine-Orjented Activities: A Study of ths Southern Hew England Marine Region (Kingston, R.I.: Agricultural Experinent Station, Bulletin \#396, 1967). 
example of this study orientation touching on coastal develcpment problems is, Our Wation and the Seg, a report of the Commission on Marine Science, Engineering and Resources. 4

In short, these studies deal with what should be taking place on certain coastal areas; what is taking place in a given area and what problems this is creating; what is the economic impact of specific coastal activities; and finally, what are the overall changes occurring on coestal lands. The studies focus on coastal planning, economic, ecologic, and administrative considerations, but do not deal with how coastal policy formulation is currently being accomplished and the policy implications for the future in a limited area of the overall coastal environment of the Country.

II. Review of Literature on Planning, Public Administration, and Policy Sciences

Having found little directly applicable information dealing with coastal environmental management, literature dealing with the achievement of environmental quality was searched specifically in those works which reflected a planning, public administration, or policy science viewpoint. It was felt that a public administration approach might be the best framework for analyzing local coastal policy formulation processes.

Policy making is defined as the setting of courses of action designed to implement the values, usually of a large number of persons, on a given issue without unduly compromising other values on other

${ }^{4}$ Our Nation and the Sea, Commission on Marine science Engineering and Resources (Washington, D.C.: U.S. Government Printing office, 1969). 
issues. 5 Because public poljcy must incorporate comeunity values to be a heaningru]. guide, it was recognized that a framavork for discussici would have to be constrveted which would incorporate a wice variety of factors that reilect these values but wingh theruselves influcnce decisions. Plaming literature, especially Dyckmin's article entitled, "PJanning ara Decision Fheory with Extensive Bibliogrephy," helped to defire the thonght that decision-makirg reflectiag commity values occurs mest clearly vithin a local context. ${ }^{6}$ Simon's Anininistrative Beharior and Schickele's book, Aericultural Policy, presented a puoljc administration viewpoint toward the elments which constitute the decision-making process in an administrative organizetion.' Jazrett's book, Eryirongentol ouslity in a Growing Econory, helped to syrthesice these earlier readings in dealing with e rpeciric subject issue. This book, hoicver, presented only an economic point of viek. 8

Unfertunetely, these books, thoxdh identirying importent conecptual armroches and issues in decision-moking focuscd on environdental questions, failed to show the actual nathodolody for bringing three

5R. A. Bauer, ard K. J. Gergen, The study of Policy-Fomulation (New York: The Free Fress, 1958), p. 3 .

$6 \mathrm{~J}$. W. Dyckum, "Planning and Decision Theory with Extensive Bibliogralky, I.A.I.P., Vol. 24 , Nov. 1961, p. 211.

7H. A. Sinon, Administrative Behavior (New York: The Free Press, 19'5). R. Schickele, Asricultural Folicy (New York: Nocrar-Hill, $1954)$.

8. Taryett, Ed., Errvironental Quaisty in a Crrowing Econony (Baltinore: Johns Hopkins Tress, 1956 ). 
ebstract considerations into an empirical evaluation of actual policy formalation processes.

A laxge hody wf litercture doos exint, however, which deals with Epproachas to studying actual comanity decision behavior. Mann's article ciefincs thrce aproseres: ${ }^{9}$

1. The decision-maker approach which concentrates on the backryounds and personal atixibutes of decision-nakers, e.z., Robert F. Kenneriy, Thirteen Days: 10

2. The partisan approsch which looks at partisans of a compunity isslie, controversy or conflici, yoner and influence erployed by inierests, and perconsl poirer, e.g., Floyd Hunter, The Cormunity Power Structure; II

3. The process approch, which follows the course of issues and ciecision-making enbeddel in a reb of socinl relationshins, e.s., Meyerson ard Benfiel, Politics, pinning and the Publis Interest.

It was at this point that readings from the new field of policy sciences becurne applicable. Policy sciences ere un interdjscipine focusing on public policy making and based on behavioral scierces and analytical ajproaches. ${ }^{13}$ To date Yehezkel Dror has provicied the most lucjd writings on this subject which include the developnent of a general fremework for evalualing public policy and presentation of an

91. D. Mann, "Studies in Comuuity Decision-kaking," J.A.I.P., Val. $30, \mathrm{Fcb} .2064$, p. 47.

10 R.F. Kennedr, Thirteen Days (New Yoxk: Norton, 1969).

1] F. Hunter, The Conrmity Poner Structure (Now York: Doublcday Anchor Booke, 1503).

${ }^{12}$ M. Meyerson, and E.C. Banfield, politics, Planring and the public Irterest (Now York: The Freo Press, 3955$)$.

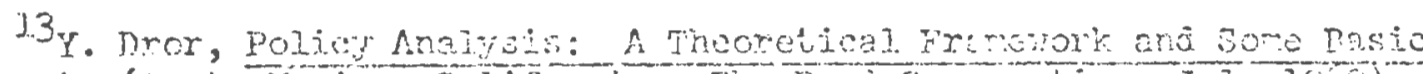

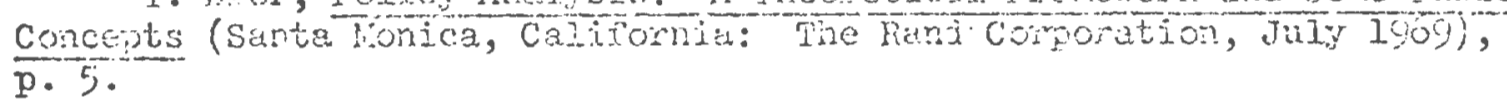


optireal model of public policy-making. Using thuse readjngs, it vas then possible to adapt certein concepts, such es the decision-mating fiejo,

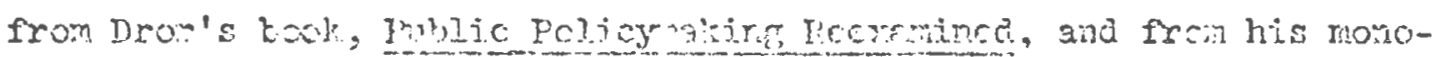
graphs issure from the Rani Corporation. ${ }^{14}$ Es juxteposing those approvehes outined in the Mem article with those ideas presented in Dror's borlis, 2. conceptual fromework for the detailed discussion of such diverse ceajsion-maring factors as politics, plannine and the rarket.. place was crcated. This framork is discussed ju dctail in Chopter II. It mas hop that the integration of several approsiches into a new framework migh rot mininize the effect of the interaction of decision-mating factors jn discussing real decision sibuations. Down' book, Inside Bureacracy, helped crystaljze the idec that because public decisionmakjus deals with problens with multjasciplinary facets, analysis or their decision processe; should be from a wulti-disciplinory point of view. 15

IIS. Construction of an Anolytical Framevork

The approach applied in this stury drens on selocted concets fron the aforementioned sources in the creution of an enilytical fremevork for evaluating coastal policy formulation processes. The central concept used for this discussion is that of the decision-making field, the context in wich decisions are made. Although recogrized by mamy euthors in the above mentionsd disciplines, the best explanation of the

${ }^{14}$ Y. Dror, Public Poljeymaring Reexinined (San Francisco: Chandles: Press, 1.068$)$.

15. Dons, Inside Bureaneracy (Boston: Littie Brom Co., 1967). 
way this decision field influences planning actions can be found in Bolan's article, "Emerging Views of Planning." 16 In this study the concept will be applied as a framework for the discussion of not only planning as a decision factor but also for other factors influencing decision-makers operating in the local context or decision-field.

Principle readings used as a basis for these factors are: Planning (Dror, Meyerson, Bolan), Politics (Hunter, Dahl, Wilson), the Market place (Barlowe), the Economic-Ecologic dichotomy (Boulding), and Jurisdj.ctions and Controls (Kumekawa). 17

IV. Selection of the Study Area

Having established a conceptual approach and organization for discussion of the local policy-making process on coastal issues, the selection of a study area was required. It was felt that only a portion of the Narragansett Bay shoreline could be convenientiy handled. In choosing this study area the following criteria were used:

1. The coastline must be a single uninterrupted segment, spanning several municipal jurisdictions.

2. The area must exhibit various stages of development from high intensity to open space.

16. S. Bolan, "Emerging Views of Planning," J.A.I.P., Vol. 33, July 1967, p. 241 .

17 Dror, loc. cit. M. Meyerson, "Five Functions for Planning," J.A.I.P., Spring, 1956, p. 158. Bolan, 10c. cit. Hunter, 1oc. cit. R. A. Dahl, Pluralist Democracy in the United States (New York: Rand MCNally, 1966). J. Q. Wilson and E. C. Banfield, City Politics (New York: Vintage Books, 1963). R. Barlowe, Land Resource Economics (Englewood Cliffs, N.J.: Prentice-Hall, Inc., 1958). K. E. Boulding, "Economics and Ecology," Future Environments of North America, ed. F. F. Darling and J. P. Milton (New York: Natural History Press, 1966), p. 225. G. Kumekawa, "Toward the Formulation of a Regulatory Framework of use of Narragansett Bay," (1967), a study report to the Natural Resources Group for their study, Report on the Administration of Narragansett Bay, Jan. 7, 1969. 
3. The runjcipalities controlling the costline should represent a significant percentage of the state's population, and lave different forrs of governimt.

4. The coastline mot be in an area of rapid population groith.

5. There must be a professiona planing offine in at least ha? the commutios.

By applying these criteria it res thought that the study area rould be a represcniative sarple of the Nerregansett. Ray coestal environment and that the armple would reflect some of the chanes, issues, and levels of environental manasement expertise that the state currentzy deals with in raking resource allocations for coastal land-uses. The study area encorpasses over $1 / 4$ of the shoreline of Narragansett Bay, and is located in the cities of Cranston and Warwick, and the towns of East Greenwich snò North Kingstom.

V. Selcajon and Application of Data Techniquo

Because the analyitical. framework used for this study (chepter II) seeks to explein current decision-making processes, it was felt thet a prefatomy chapter (Chenter III) was needed to trace the historical. dovelopment of each study area municipality, and to describe contemporam coastal land-use patterns.

To prepare this chapter, historial literature for cach tom was revieved, fiela investigations of current land-use patteme vere made, and key officials concerned with local development were interviewed. In order to build on the framanork established in Chavier II, data was needed from each tom from speciric intervicweos. Selection of intervierees was accoplisined througk a four phose 
approach: (A) newspapers for the previous ycur were searched for coestal issues and associated porticipants in each communty; ( $B$ ) the governmental orgailiation ond charter for euch municipality was scarched to identify wijuch board, or body of government was most likely to he legaliy rospcisjble for constel concerns; (c) top auministrative of were interviried to foxmulate a list of names of those most active and influential in coastal environmental issues; (D) top elected officials were contuctcd to provide a sinilar list of names sugested from the comanjty at large. By cross rejerencing these nalies a list of key decision-nakers for coastal environmental concerns was derived. Fron this totol, a variety of Eovommental and comrunily positions were dofined. In every comitnity a nember of the council, the administration, and conservetion interests were selccted for intervitwing. Where possible in these categories individuals wore chosen who held multiple positions. Such a position might be a councilman froit a coastal ward who was also on the council investmont or ordinance cormittee. The following list indicates the distribution of these positions in the study area.

$\begin{array}{ll}\text { City ow tom councilmen } & 4 \\ \text { Administrative Assistants to Mayors } & 2 \\ \text { Professional Planners } & 2 \\ \text { Conservation or Waterfront } & 4 \\ \text { Comission Members } & 1 \\ \text { Planning Board Chaiman } & 2 \\ \text { Torn Manager or top appointed } & 1 \\ \text { Administrative official } & \\ \text { Redevelopment Director } & 2 \\ \text { Top Local Political Leaders - } & \end{array}$

These injividuals hold a variety of posjtions necessitaing the inclusion of a varicty of questions which rould apply to their respective positions. The intervier format oricinolly consistes of two parts. A 
14

personal interyiew (Appendix A) in which the questions were designed to focus discussion, and a miled intervicw (fppendix B) to be completed and returned in envelopes provided after the completion of the pexsons.l intervich. In the custionaire to be maler, specific factual or preference information was sought.

The construction of the interview form went througin four revisions refining the lenguage of the questions. The form and intervitw format were then fre-tested on the Ncwport city mangger wilich revealed severel short conings in tersns of intervies length and the noed for specific examples illustrating the types of information sought. After the first seven intexviews, it became apparent that the mailed interview questions were not being returned. Because of the restricted size of the semple (18), jit was necessary to sustuin a hjgh percentage of conpletion in orber to heve meaningful results. The intervier formet was then changed so that the porsonal interview would include completion of the questionnaire to be mailed. This ensured a one hundrad percent completion of Appendix A and resulted in an eighty-seven percont completion of Appendix B. This latter percentage vas supplenelitcd by infortution from councilnen, administrators, and board neribers where complete interviews were not possible. Five adeitional intervievs vere partially completed for Appendix $B$ in this mannar. Fach interviev averaged $l-l / c$ rours in length.

VI. Intervicwee Bias

Intervieree bias falls into three types. Sorse of these biases are outronthis of the corstraints on the local dossien-mater. These constraints are: 
1. Limited amount of time to make decisions.

2. That each decision-maker can weigh and consider only a. limited amount of information at one time.

3. Officials have multiple involvements therefore can not consider all simultaneously, hence they tend to focus on one or two areas they know best with the rest remaining uncared for.

From these constraints several biases appear:

1. That interviewees tend to stress aspects of environmental issues which they are most familiar with, but which are not necessarily related to coastal changes occurring in their community.

2. That past programs or actions toward environmental concerns tend to be evaluated in terms of the decision-maker's personal values rather than objective performance standards. What he wanted to have happen is of foremost importance rather than what did happen.

3. Because of lack of technical information or lack of facility in handling it, decision-maker's personal values tend to supplant objective discussion of future coastal environmental issues and their resolution.

VII. The Case Method

Because the analysis of each town is organized around the aforementioned decision-making factors of planning, politics, the marketplace, and others, it was necessary to present direct observations of how these factors interact in real situations. Chapter $\mathrm{V}$ accomplishes this using the case study method. This case study through meticulous description attempts to document this interaction. The main advantages of the case study is that it forms a continuous picture of events as they unfold. The major disadvantage is that cases take too long to prepare, that objectivity is difficult to maintain and that 
those interviewed in the case preparation tend to stress unusual events or aspects of the study issue. ${ }^{18}$ Case preparation included researching of published documents and interviewing participants. Researchers have found informal interviews encourage freedom of discussion thus rlelding the most informative results. ${ }^{19}$ This held true for the cases prepared in Chapter $\mathrm{V}$ and Appendices $\mathrm{C}$ and $\mathrm{D}$.

18 . Gee, Social Science Research Methods (New York: AppletonCentury Croft, Inc., 1950), p. 248.

19 . Hillwey, Introduction to Research (Boston: Houghton Mifflin Co., 1956), p. 218 . 
II

CHANGE AND THE COASTAL ENVIRONMENT:

DECISION-MAKING 
Coastol Land-Use Change

The edge of the sea reflects in its land-uses the aiversity of: values represented in the United states both in the past and present. These values are expressed in the way commuities sanction the use of coastal lands. In the earliest days of tinis country, small development centers for trade End culture were established at the moiths of rivers and in protected coves. Compact waterfront areas characterized by docks, warehouses, residential and community usis reflected the major societal values of the time. These values vere in the idenl of work to translate the raw wealth of the natural environiment into commodities for trede which supported the nation's desire for economic, social, and religicus indejendence. Wateriront lend in these small citjes becams valued becalise it provided a locale for comonic and social exchange betiven land and sea.

As our econorry has grain more sophisticated, our institutions for economic growth and sustanence have moved from on ogricultural base to an industrial base concernod vith the production and transier of durable goods. The growth of these institutions and their manifest impact on coastal lands has resulted in a segregation in locality of economic and social institutions.

Manhattan Island best typifies in i.ts coastal development this paredox. Because the physical manifestations of large economic institutions such as shipping, warehousing, and manufacturing dominate tine shoreline with their massive structures, the groat majority of Manhattanites have been excluded from enjoving the majos aspect of the natural enviroment of the city. Social instituitions and jublic places 
of interaction are not placed in a location or form which is conducive to enjoyment of this last major natural resource for the area: the waterfront.

As we move into a service economy, such coastal environmental resources are in increasing demand for recreation, reflecting society's desire for leisure activities. To fulfill tis need, large areas of coastal lands have become oriented toward a recreational economy and land-use patterns. Such a pattern consists of seasonal homes, marine oriented activities and commercial facilities.

On the metropolitan scale of the coastal Massachusetts region, the Cape Cod National Seashore and Cape Cod itself can be considered as reservations of natural areas of a dinension suitable to serve the rapidy growing residential and transient population of the region.

While the sea coast in its natural state offers exceptional potentials for recreation uses, its scenic qualities offer assets for commercial and high density residential development that are hard to match. Miami Beach, Florida, provides the most vivid example of how the recreational qualities of an area can be used as a nucleus for large scale commercial and residential proposals. In 1913 this strip of mangrove and sand was acquired for 35 cents per acre. Today this value has appreciated to $\$ 200,000$ per acre. ${ }^{1}$

Proximity to the sea for this type of development, however desirable, offers complex problems for designers unless ecologic as

\footnotetext{
limhe Today Program," N.B.C. News, March 2, 1970.
} 
well as cconomic criteria are recognized. In 1952. the New Jersey shoreline on which rendom developinent occurred was laid waste by a violent storm wich destreved several lives, and over 2400 houses with three times that mony danged. In total, over: $\$ 83$ milizion worth of destruction occurred. ${ }^{2}$ In this case the coastal environient was returned to the natural state by min's ignorance of naturel processes.

In similar, but in less dramatic ways the coastine of Nirraginsett Bay has experierced the types of changes expenjenced in both Mami Beach and the Ney Jersey Coast. Curjently, a large coastal motel. in Cranston, R.I., is being expanded by the Hilton Hotel Corporation with facilities for meetings. High incone condominiuns are being proposed on coastal lands in North Kingstom. In 1954 many homes on Werwich's Conjliteut Poin' rere destroyed by a huricene.

It is possible, and logically desirable to have both econonic develoment through location of comrarcial, residential and irdustrial facilities on coastal sites and preservation of natural coastal areas. To do this, a rational and compehensive approach to coastal enrironmental managenent can be employed. By piecemeal development through narrow and overlapping municipal and functional jurisdictions, random coastal development threatens to exclude the great majority of urban dwellers from enjoying the unique qualities of the coastline. In adiition, unplanned dovelopment affects the eiviromental quality of the Bay itself. Water pollution is a nanifestation of thsse random

\footnotetext{
2I. J. MeYarg, Desjen vith iature (Ner York: Natural Ilistory Press, 1969 ), p. 16.
} 
development patterns.

Though man is wholly dependent upon an ecological balance in nature to provide air and water, his technology has allowed him to create the alternate environments of our urben centers. The degree to which man is able to apply this technology in both preserving and using his coastal environment depends on his willingness to accept a role of constraint in a global ecological system of natural resources about which he has much to learn. As our knowledge of these larger ecological systems grows, the folly of smaller localized development decisions often become apparent.

The destruction of shore property on Warwick's Conimicut Point in 1954 had occurred earlier in the hurricane of 1938. It was not until the area had been severely damaged for the second time that development was stopped by law. Clearly such a policy decision as this was reached only after considering many factors. Each factor in this and other local coastal land-use decisions become then a cormonent part of the final decision on a given issue.

\section{COASTAL ENVIRONMENTAL MANAGEMENTI:} DECISION-MAKING

Local decisions are being made daily which affect the coastal environment in the West Narragansett area. Because considerable development pressure is mounting on the coastline of the study area, local public decision-makers are faced with many difficult development issues to be resolved. The decisions made on these issues are based on both the factors that are perceived and weighted by the decision-makers and on the conditions that prevail when decisions have to be made. 
Four conditions interact to affect the manner in which decision factors are considered. First, decision-makers have limited time and information resources available in helping them clarify coestal environmental issues. Second, increased speculation on cosstal lands creates pressure for action which does not lend itself to careful appraisal of the regional or sometimes local consequences of private action. Tbird, conflicts in coastal land-use occur such as major industrial or military facilities which provide economic benefits while also creating new environmental liabilities such as pollution. Balancing the potential for environmental loss to the community against the fiscal benefits of such developments is a difficult task. Fourth, the many issues facing the local decision-makers can best be handled through the coordinated efforts of several governmental levels. Bay functional jurisdictions and local controls overlap, however, and are often 111 suited for dealing with specialjzed problems in coastal environmental management.

To understand fully the effect of these specific condjtions, it is necessary to outline the overall context, or set of charecteristics, of the community which interact in defining the decision-making factors which are the basis for development decisions and policy formulation.

\section{THE DECISION-FIEID :}

A MECHANISM FOR FOCUSING DECISION-MAKING FACTORS

- Unlike the businessman whose primary system of accounting is easily quantifiable into profit maximization or return on investment, the public decision-maker is faced with multiple and often conflicting measures of accountability and public expectation in his atteupt to 
successfully execute his duties. In addition, each decision-maker is operating in a commicatious network wich is commity-wide, thourh sometires highly specialized, in the scope of its irifornation content. An exarple of a highly defined scope of information content wight be the vjews expressed by affected Jand owners in a coastal urban renewal issue (see Chapter V). A broaker scope of information content carried on this conmucations network njght be those views expressed by business or social organizations seeking to imorove the physical form of the city through coastal renewal. From this overall network the decision-maktr often receives divergent views for policy emphasis. The decjsion-field in which he rakes decisions can be derined in terms of the inieraction of the following characteristics j.r a given commity. Mose chäneteristics we crporsed in the soures for and in the content carried on the communications netrork.

1. Functional specialization (both within the local government and in the major institutions of the coinumity).

2. Social differentiation in the combunity and in the particular political area being represented.

3. The degree and character of leadership. ${ }^{3}$

The importance of the decision-ficld lies in the manner in which it organizes the factors involved in any coastal decision. Not only does it tend to make them fall into a rutually acceptable terminology and levels of complexity familiar to the decision-malers, but also it tends to affect the manner in which solutions are sought. Thus the

3R. S. Bolan, "Cormunity-Decision Pobevior: Tile Culture of Planning," J.A.I.P., Vol. 35, Sept. Ió, 9, p. 87. 
decision-field not only creates the forum in wich decisions are made but also patterns the group dynanics on the decision-maks seeking to resolve cossta.l develonment issues.

Norton Iong hes defined the interaction of these characteristics of the decision-field in a game metathor. To these characteristics he hes added a consideration of the personal motiviting forces which evidence themselves when groups interact to accomplish a given task. Lonf states his metaphor in the following maner:

Within each game there is a well established set of goals whose achievement indicates success or failure for the participents, a set of socializen roles making participant behavior highly predictable, a set of stratcries and tactics handea down through experience and occasionaliy subject to irurovemort and chancre. In such a gare there is an elite public those appropriation

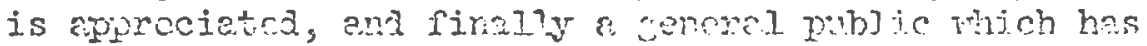
some eppreciation for the stsinding of the players. Within the eame the players can be rational on the varying degrees that the structure pexmits. At the very least they know how to behave, and they know how to score. 4

Having broady derined the decision field or local context in which decisions are marle, five factors can be discussed which form the basis for coastal enviroumental sanagement policy on the local levej.

DECISION-MAKING FACTORS :

PLANNING, POLITICS, THE MARKET PIACE,

THE ECONOMIC-ECOLOGIC DICHOTOMY, AND JURISDICTIOIS-CONTROIS

PJAANIIING

The Planning Professional:

The role of the planning professional. in affecting commuity change

"N. E. Long, "rihe Iocal Ccrmuniby as an Pcolomy of Gar:sa," American Juurnal of Sociolosy, Hovember 1958, Tr. 251-60. 
has received increasing attention in recent years. Unlike his colleagues in law or midicine, however, there are fewer establishcd jimits to the planner's professional responsibilities. In the narrowest viev the planrer is concerned with the arrangernent of land-uses. According to the Americen Institute of Planners 1968 stateinent of professional responsibilities, the focus of the profession and its merbers should seck the following form:

The work of the planning profession jis related to the collateral fields of social, econonic and fiscal plannj.ng. Its accomlinhients are expressed rrimaxily through detexiningions of the comprthensive arrangor:ents of ianduses and land occupancy and through their regulation.

Since the basic objective of planning is the promotion ci the general velfare, the irofessional planrer respests this as the pararount corsicleration in the conduct of his professional aciivities.

The professional planner recosnjzes all land as a natural rosource and acknorledges the pribey of the public interest. Guided bir these hasic principles, he will. seek, in advising on comprehensive arrangenents of land-uses and occupancy and their regulaticn to proinote and yrotect both public and private interests as may be proper and appropriate to each situatioil.

Because the planner has no sanctions by which to enforce his opinions, he rust be a skillful manipulator of people to achieve his goals. This end is sometines reached through action as an asent of change in creating conflict and conflict resolution through the use of plans and the legal tools which are the primary forces behind implementing planning proposals. These tools are the zoning ordinance, subdivision regulations and the capital budget, each of wich the planner.

\footnotetext{
5 Anerican Institute of Planners, Hendbook, 15,58, p. 30.
} 
prepares but must depend on others to adopt. Because the profession can be scen from widely differing viewpoints the planner's role is further complicated by a lack of precision in the technical language of his trade. The combination of these elements tend to create heterogeneous views in the professional planning ranks as to what planners do and to whon they are responsible.

The Planner and the Comprehensive Plan:

Planning is viewed as a series of related actions and decisions that are organized around and moving toward the accomplishment of objectives. 6 It is usually accepted as a continuing process rather than the construction of a comprehensive planning document. A comprehensive plan is an official public document, encompassing all geographical parts of the community and all functional elements which bear on physical development. It is adopted by a local government as a policy guide to decisions about the physical development of the community. ${ }^{7}$ Local government is the only body now capable of coordinating the overall pattern of physical development. The plan in text and maps acts as a framework in which daily public and private development decisions can be organized.

Three elements are usually included in the plan. These are proposed land-uses, circulation, and commity facillties. In addition, other considerations such as urban design, population and economic

6. I. Goodman and E. C. Feund (eds.), Principles and Practices of Urban Planning (Washington, D.C.: I.C.M.A., 1968), p. 327. 7 Ivid., p. 349. 
studies; and development goals and objectives are usually included.

Preparation of the plan is asually the primary task of the plancer. When this is accomplished, implementing and interpreting the plan for specific public and private developuent activities becomes his major pre-occupation. In order for a cornprehensive plan to be considered meaningful as a doauneni guiding coastal developrent, five ninimun stantards must be met. These are:

1. Clarity in terrs of derining coastal resources and development objoctives.

2. Internal consistancy.

3. Scope, in terms of time span.

4. Conprehensiveness, in terms of variety of coastal activitjes it deals vith.

5. Operationability, in the sense or being copcrete enourg to be a reaningrul glide to action.

No matter how high the quality of the plan j.tself, it will have little impact as a guide to decision-making unJess the planner continualiy makes the plan the foundation of the ccrkunity planning process. While this process may difjer widely in sequence and content from place to place, five key functions can be used to apriraise the effectiveness of the planmer in kecping the planning process as a forceful factor in the decision-field. These functions are:

1. Centra, intelligence function.

2. Pulse-taking funcion.

8 Standards user are based on concepts incorporated by Y. Dror, Public Polic, whira Reoramined. 
3. Policy clarification function.

4. Detailed development plan function.

5. Feedback function. 9

The Planner in Government:

While the planner is not sure what he is, or what he wants his role to be, those allied professionals in government often view the planner with reservations. A key point in this real or latent antipathy is that the planner seldom works his way up through the ranks to his position near the top of the governmental hierarchy, but instead achieves his status by lateral entry. To obtain such a key position in this manner rankles the civil service advocates. Planners are selected by top decision-makers and deal primarily with them and with the top administrative agencies of goverriment. In addition their province is not limited to their own department, but demands them to cut across departmental jurisdictions in devising plans for community development.

The debate resulting from the confusion over the correct role of the planner in government has resulted in several variations of the placement of the planning function in government. Four generalized positions are definable, each of which offers a differing impact on the decision-maker according to his own position in the governmental hierarchy and with the complexity, size and perception of the environmental issue to be resolved. The positioning of the planning function

9. Meyerson, "Five Functions for Planning," J.A.I.P., Spring 1956, p. 158. 
will vary rrom town to town depending on historical factors as well as on the degree of professionalization and centralizing of authority. Although the impact of planning, especially in smaller conimunities, depends on rrofessional competence and personal comunication ability to function smoothy vith decision-rakers in the decision rield, its location in the governmental structure has a significant effect on the planning strategy employed by the planning function to bring plans into reality. Four positions for the planning function have been defined though others are recognized and offer variations on these. ${ }^{10}$ These positions are:

1. Robert Walker (the Walkei position) has suggested that the planner be ermloyed directily by the meyor and by this proximity will thus be in a position to directly imole.. ment tho comrehensive Plen. He cen, therefore, contribute to the effectiveness and pace of muicipal development in the strong mayor form of coverment. 11 The Valker position is demonstreted in this study by the role of the planning function in Cranston and Warrick (See Chaptes: IV).

2. T. J. Kent (the Kent position) stresses the effectivenes, of the planner as the employee of the legislative body. Ii Bolan notes that this position appears to work well in Council-1:anager forms of goverment, but in the larger cities with highly diversified representations in Council, reconcilement by the plaming function of inter-ivard conflicts becones an Herculean task. (The best case example of this position has been documented in Banfield and Meyerson; Politics, Planning and the Public Inierest.) The position is demonstrated in the study by Wariick's Waterfront Development Commission (See Chapter IV).

${ }^{10}$. S. Bolan, "Ererging Views of Plenning;," p. 242.

$1_{\mathrm{R}}$. A. Walker, The Planning Function in Urban Government, Social Science studies, No. 39 (chicago: University of Cricago Press, second Eủition), 1950.

12 i. J. Kent, Jr., The Urban General Plan (San Pxanciscc: Chandler Pubiishing Co.), 1054 . 
3. The Goolman position (described but not edrocated by that writer) describes a posicion of the planning function as dircetly under the governing body as a whole or one of its comittees. This form is ususily found in municipalities with weak exceutives or those with a board of supervisor's where no single regber has strong voice in making decisicns. Where decisions ane made by a grouxp there is no single point, surh as the mayor's office, where planning decisions car ke taken. This position is exemplified in the study area by Fast Groenlich's plennirg ruaction. 13

4. The fourth position is that of planning by Ad Hoc committees created by tom mecting to aeal wilh special problems. This planning pattern is used in North Yingstown as an auxillary information source to the yjamning Board and also as a means of deriving community consensus and misirum interaction and participeition in irriving at policy positions. This type of positioning of the planning function is often used in Nev England where town metings still prevail.

The Plenner in the Comunity:

As a result or the planner's juprecise role and ability to draw on the resources of nany goverimental agencies he is often required to bargain and aibitrate anong the various interest groups within govern.ment and the commity. More often than not it is through the use of zoning that such arbitrating roles occur.

The evolved rationale of zoning has been hased on the protection of the single-Ianily home and local business. Though zoring is not comonly viewed as tool for econonic developinent, it is often employed to Iimit coinpetj.tion. Through application of the poljce powers the planner, knowingly or not, is maximizing certain values of segments of

13W. I. Goodnan and J. I. Kaufman, City Planning in the Sixties: A Restaterient of Princinles and Techniquss (Urbana: Bureau of Conmunity planning, University of Ilinnojs, 1965), p. $2^{\frac{1}{5}}$. 
the cormurity such as the decision-makers who hired hin. It has been said that a 2lanier is never hired by a comurity untij the commity wants to limiti population size or corpetition from outside sources. Because interaction of factors in the decision-fje?d of a given comm runity may rasult in the emphasis of certain strongly held values, the planner is ofiten tacitily cxpected to have these reflected in his plans. To the outsider these values are sometimes synonimous with local pre-juaices. j!t $^{1}$

These coirnunity valies can be expressed in many forms. It has been arcued that the planner should also fairly represent those values which may not be as widely held or vocally supported. In some irstances envirommental quality has been sacrificed because values which hold higher esteeri for econoraic develowent prevailed over values which favor ecologic considerations. For the public decjsion-naker without facts on the ecological benerit.s of coastal environmental preservation, traditional values favoring economic devejopment on cosstal lands may seen more valid and bring greater returns to the comunity than cosstal enviromental preservation which entails maintainjng rather than creating a rev conunity resource.

Often the planner is expected to counterbalance the economic values expressed $b_{y}$ the market place. Of course, in those instances where government reserved certain coastal resources they have exercised their inherent porers to purchase through the merket, concemn market

14 R. S. Rabcock, The Zoning Gare (Hadison, Wisconsin: Univcrsity of Wisconsin Press, 1599$), \mathrm{p} .65$. 
judgments, or direct market valuations by use of the police power. Zoning, the primary tool in the exercise of this power, remains restricted in application because of its evolved rationale which has no recognition of ecological principles. Rarely has zoning been successfully employed as a means of bringing about desired change in an area which has already suffered from environmental abuses. Provisions requiring discontinuance of non-conforming uses are subject to prolonged legal battles, while being politically unpopular with legislators sponsoring environmental. improvement.

Clearly local decision-makers must be concerned with defining which development choices reflect economic values and those which reflect other social values. This can be accomplished by improving the connection between ecological and aesthetic responses and market responses. It is for the planner to make the distinction between development proposals reflecting different values clear to decisionmakers. He must make the consequences and benefits of each explicitly known if he is fulfilling his role in the community as defined by his professional society.

If coraminity values for coastal economic development are expressed in the interaction of the fectors in the decision-field, who then is responsible for the equitable redistribution of resources that accrue to the community through this economic growth? Clearly, the leaders of government and their associated planning staffs represent the nearest thing to a "social diseconomies board". Their role is to reparcel the gains and losses emanating from their consent to changing land-use and environmental patterns. In the allocation of coastal land and 
environmental resources this role is especielly inportent because of the limited auping base.

Plannings Statesic:s:

To cairy forvard planing developrent proposals, the plamer mist not only ba sensitive to the commuty values that manifest themselves in the decision-field but also most have a conceptual approach to the task of iruplementation and comiunity change. The ability of the plan..

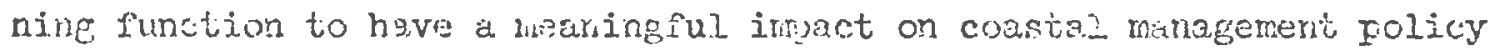
denenas a tive adrinistrative and professional streibth, degree of diffusion of porer in local governnent and the position of the planning function in the fovernmental structure. Cleerly ci coastal development plan which denands a consistant schedule of land acquisition, federal partjeipation, racilities programuin, and involved municipa] regriation cannot hope to be realizod in a Governmental structure, both political and administrative, which is incopable of handling such a compley aproach to envirommental managkisent.

Friedmann defines two generaljued categories which encomoss six planning strateries. Planning strategr means the mannex in which the plarner ettenits to direct comurity change which is occurring becaise of his efforts or outside forces. Friedmann's categories are named odaptive and developmental planning and are defined as follows:

Adaptive planing is interested chiefly in qualitative adaptations to the changing inteiplay of ecoroinic forces vithin an area; while develop. antal planing is coinexned with achieving a bigh rate of cumlative-jnvestinent for given area by activating unused resouxees capabilities. 15

Is J.Friefrann, "Regional Develowant in Post-Industrial Society," J.A.I.P., Vol. 30 , Mey J.96', p. 71 . 
Adoptite Plsnning is comnonly found in staller commities where weak or ion professional input is present and where there is aiffused authority. The Gooinum position and Ad Hoc Cormileee position described on page 29 usually are the basis for this aroroach. Developiturtal planning is best operable where sirong professionalizatian and centralized anthoxity are present. The Walker position and to a losser decree the Kert position rake this amroach possible, althorgh certain positions are not prerequisites to using these arprosches. Adaptive Planning:

Strategy (A) The Catalyst-Coordinating Stance. - The purpose of the plaming is to respond by minimizing the disruptive aspects of community change and to control private develonmenta? immat through the coondination of ccmmunity expenditures. An example of this approach might be the extension of muricipal sewer services to alleviate groura water pollution in an unplanned subdivision loation.

Strategy (B) Ad Hoc Opportunism. - Though not widely acknowledged as an operational method of decision-meking in the planning function, this approach involves the pursuit of idealized end states about whjch widely differing perceptions may be held, but toward which no concerted scheduJe for accomplishent if framed or program set. In short, it is a highly flexible approach not prone to arousing cormuity anipathy, or interest. An exarple of strategy B would be the plain of creating strip commercial developrant near public bcaches as a means of encouraging ecormic development. Such a stratery segks to raiionalize througin public sanciton the forces of political and economje factors in the decision-field. 
Develognentul Plonning:

Strategy (c) Systens Arilysis and Simulaion. 16 - This technical auproach serks to remcreate in metheinatical models the integratcd systons or fluctions in the comunity, which through projective computer analysis yill provicie the planning function with detailed informatjon on the effects of alterrate investment or cievelopmental strategies. Jdeally by being able to explore more options better decisions can be marie noi: without foreclosing critical future choices. While itis operative use is currently limited as a method it has provel an invaluable aid to institutional development for corporations with their erphasis on internal systems control. Sirulations of coestel recication demands through extranolations of curent origin und destination studies in conjunction with attitudinel studies can be considered an exingle of this strategy. Because of the complexity of the systems being dealt with or an urban scale, stch as the Providance SWisA, this stratcis has to be considered more theoretical than practical.

Stratecy (D) Cost Effectiveness erde Prorrar P.annine. - Buton Fi. Klein of the Rand Corporation has been credited with defining this approaen to planning. ${ }^{17}$ It is basea on the posiulate that all. information needed in the formulation of policy camot be gathersd in the initiation of formulation piases, but instead must be determined as

1.6 This concept was documented by P. S. Bolar, "Eniverging Viciss of Planning", $\mathrm{n}$. 240, and orjeinally eleborater by $\mathrm{C}$. J. Hitch and R. N. NeKe:in, The Eccionics of Defense in the Machear hag (Cambritge, Mass.: Harverd University Is ass).

]'7. F. KIein, "iho Decisicn-maing Irosiem in Develoment", in National lumad of Econcinic kesesuch, nhe Rate ard Dircrtion of Inventive Acitio (P.inceton, N.J.: Princeton University Press, 195a). 
the process is carried through. It is necessary, therefore, to delay decisjons on plicy metters untjl alternative keproachez can be conceived end tested from information culled during the process itself. This plaming stritegy is exirencly wall suited to poljey which deals with easijy quantifiable costs and benefits that can be agreed upon and trenslated into some sort of utility unit or lieasure that is applicible to camuser handling. Such well known techniques as PFip (ProExan Fvaluntion and Review Techique) and the Critical Fath Method are now being mojified for use in urban planning decision-raking. The Epplication of this metrod thoveh operationally limited is one which progressive and well staffed plenning offices are moving tovard. An example of this strategr might be in detemining the best approacin or policy forl seber and witer line extcisions into constil areas by quantifying costs to the community ard those be passed on to the developer. Such an approach might provide a fiscal sriteria in determining sites for coastal development.

Strategy (E) Strategic Service Allocaticn. - This approach rolds that the strateric placement of public investrent and controls can act as a fulcrum to direct private investment io accomplish the purposes of area redevelopment, plans. In describing this appronch nuebele sugerests,

that the planner might exercise an influence over developrent of the metropoliten regiens fer groator than ... resources would seern to make possibje.18

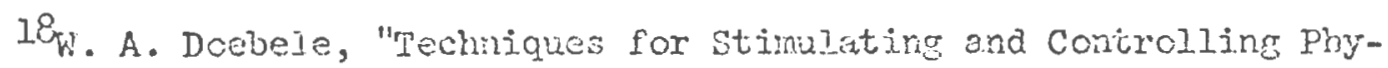
sical Developrent," Faper delivened ut the Fouth Working Conference on retropolitan Flannins and Re-jongl Develowisnt, soini Center for Urkan Struics, lesropoliton pleming Council, Ecston, June 1965. 
The strategic services to be used as the lever in conjurstion with the fulerum of public investrent are accessibility to tichays ara public transit, bosic utilitios such as hither ard swer, and detailed roplications of regulatory tewls under the poljce rorez. By using such a methol through the application of prosrantet six yoar capital budgets which spon several political terms, a consistent prorram of comminity inprovenent can be implemented. This creates a fianework organizing the dey to day choices rede ky elected decision-mokers attomping to resolye the atomistic requests of the public. The acquisition of constal conen syace, then the introduction of utilitics, rood inprovements and recreation facilities would be an exargle of encouraging the private sector to invest using prased public scrvices as incentives. This strategy differs fron $C$ above in its atemot to direct the maket inflierce tmard accomplishing public policy. Unlike $\mathrm{C}$ it places less enphasis on rigorors analysis of uroan systcirs and in the formation of prekictive molels.

Strategy (F) Conruinated Desind Approaci. - inis stiategy holds that a planned design for the form of this city rich we can perceive in the inteinelationships of physical structures can be part of the functional-econowic grouth process of urban developrent. This siralery seers to relate econonic and social activities with the geographic and topogranhic forms of tho urban site. Implicit to this approach is the assurption that social and cconomic runctions when expressed in a coondinated design presss excite the senses and motleat

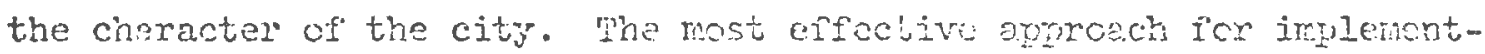

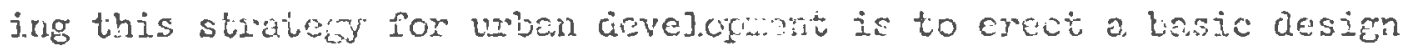


framerrork that is simple enough to be conrerehended, strong eriough to withstand the inevitable varicty of axchitectural slyies that are the components of the frumerli: yet flexible enough to aujusi to secessary chänge: 19

To successfully execute this aprowch a high degree of professional comptence ard executjue authority is required. This amprosch has been used in Philadelphia by Ecmund Bacon in a design aproach he entidies simutancous Novenent Systoms. It was actually carried out in the Pnildutelyhia Center City Plan. Such an aproach might be appljed in revitalizing cormerciol marine facilitits slich as pautuxet Cove in Cranston (see chapter v).

Having examinca planning as on juportant factor in the decisjon field in which coostal developnent policy is creared, it is necessary to examire enother factor, that of politics, which ofien contenus with planning to sway the decision-maker. POLTTICS

There are five traditional intorest eroups on the local level who most often attent to influence the decision-makers on coast.al environment issues. The key decision-mikers on coastal matters vary in number and position from town to town. Usually, however, it is one or nore mernbers of the Council, the Miyos or top planning official, plus others who have a concern for coastal riatters. The five interest. gxoups are:

1. Tre conservation comission.

19.k. Hoppenfeld, "The Role of Design in City Plenning," J.A.I.P., Vol. $25,1: 3 y$ 1960, p. 103. 
2. Landonters - residential or smil business.

3. Promotiess - developers, on real estate interests.

4. Inclientiol citizens or institutions (wich may be rari of $1-3)$.

5. The elected an adninistraivive memiens in city goveroment.

The Crnespration Conission interacts with decision-rakers via. the unique custodial role of the maintenence position. The preservation of neiural eureas and stijugent control. of developnent in or near these ervas is desired. Traditionally this group desired leaving land corpletely in its natural state. More recenty consesvation interests have stressed ecological criteria which do not prohibit human use but curefully atterpts to aroid conflicts among the biological systems of an area ind those potentially hariful aspects of human use.

Because such comissions are usually a duly consituted part of municipal governnent they interact direcily with decision-makers. This differs sonewhet from an outside Jrobby which nay seek to influenge irdividual councilmen through comrunication channcis outside the formal. procedures of local govertinent. Eecause of the Comission's position in governicht, individual councilnen are required by procedural mandates to respond to their rccomilenciations.

The Comission's effectiveness, however, may rest more on the dccision-makers' perception of the Commission's "Correct" sphere of concern or authority on environmental matters than on the particular issue in a decision situation.

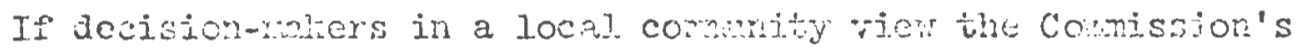
proper function as watexshed proservation, axgwants dealing vith 
aspects of a particular proposal under discussion bascd on preservation. of scenic vistes, for cxarple, ray bo discounted by decision-maters as being outricie the Commission's sphre of expertise. This sphere of excertise may also be perceived by decision-mers as being geographically based. Thus focus of Cownssion activity in rural parts of a tonr or city ray ceuse decision-; kers to seek advice of other boards m combissions in dealinit with issues of open space in more highly develoned paris of the compunity. (See East Greenich, Chapter IV).

How conservetion groups interact with decision-rakers, and conversely how decision-makers are insunenced by the cormission's position depends, in pert, on the Comission's om conception of their function. Also contributing is the perception or decision-makers toward the in. poitance of conservation to a given lown and its problems. Ihis perception mey exist quite independent of conrervation enabling legisla.tion and may be based more commonly on the persuasiveness of indivicual cormission metuers.

The Lrandomes' breadth of interests scldom spans mucil of the spectrum of environmental concerns. She strength of his position in the decision-making field lies in the fact that he is a voter from whom the bulk of municipal revenues are drawn in the form of taxes. He viers the role of the elected ofricial as spokesuan for, or steward of, his rights, being so authorized by his election. Municipal of cials are sensitive to the views of lendomers ond are prone to weirh heavily thair sentinents in celiberations. 
41

The position landomers take on a given issue depends on many unpredictable variables. For some instanes they encourege expenditure of public sunds uear their preperty in order to eppreciate properiy values; while arother eroup may strenuousiy oppose j.t for fear of the oprosite efrect. (See Chtpter IV - Waxwick.) The omers of coastal properivy tend to vitir their land as separate from tho larger issues of coastal envirowental magement. Indead they show little evidence of awareness that their property is part of a laxger unified geographic boundery. In their interaction with decision-malsers their views tend to be cxpressed in terms of public action toward "their land" as opposed to public action toward a segment of coastine (see Chapter V). The landomex's sphere of imiluence tencs to be defired to specific aspects of programs or issues rather than to influencing entire development objectives. If a town seels more public coastal recreation areas, for examle, key decision-makers are likely to Heigh heavily the views of landowers near a proposed site, but will not necessarily considor their views as questioning the value to the comnunity of coastal. recreation areas. Contrarily, honever, when landowners oreanize into a group thein erfectiveness as a political. force gains stature in ibe eyes of decision-makers who then must be responsive to the political implication their opposition may mean in a coning election. While indiviaual londomeri interact with decision-makers, this interaction may occur infordally with individual rupresentatives. When unified into a group, hawerer, wich petitions decision-mekers, their inpact and vaitrity of treir views on coastal develornert decisjons are greatly increased. 
Pronotes's or spokewen for a rarticular land-use type can be c].assified in the majority of cases as the prinamy reason for governmentel constal policy formulion. Their remer of interaction with decision-r.alters on the muicipol level is usually as official petitioner fox governonte]. eppoval. 20 such patitions might be for zonilif chemes, veriances, excepilons, or sublivision approval. (see Chapter IV - Cranston). Their appeal to decision-makers rests largely on the argument of innedite inorease in the communty tax base through ney construction, end throuch the rultiplicr effect that new business or residences will have on existing businesses. Their appeal to the decision-mater compliments both tho traditional viev that a growing city is a prosperous city; and the aesire of decision-migers to show tengisle results for their vork in elecilve orice. For the derision-mer whose full-tine occupation is busintss, the conception of increasing current assets (tax baso) through elevelopment, of resources (undereloped or poorly developcu land) for the greater return (voies and tax revenues) on investment (public services) scems nost natural. The fact that such developirent occurs on a limited resource base (the coastline) and is random in location and quality may be of less importance to the decision-maker tinan the tangible accomplishment that he can point to at the cnd of his two yeur term.

Devejopers are perceived by decision-mikers in maly ways. In some instances $h e$ is viewed as attempting to tako advantare of the

20 Unoffjeial interactions are difficult to cebsorize. In cranston

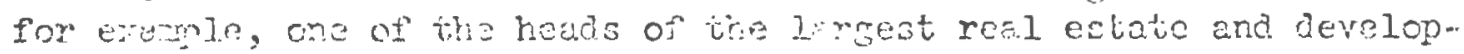
meth agertis in the staxe is a near relitjive of the rayor. 
public. The decision-maker, in this case, may vich himelf as a sentiond agairst such action. In enother case the decision-makei nuy vien developer as a political benefactor wose yioduct reflects wej.l oul electco officials during election tine. In a third insturse the docision-moker ray view the relstionship between public decisjonmakers and covelopers as an adversary systein in which municipal. administrators and planners and develoners conitend developrent issues conelly with the council ecting as the finsl arbitratos.

ritrat certain individual citizens influerce publia decisions more than others is an established frect. In sone areas such as the prestigious Potrwonat Point in North Kingstom, the quality of development reflests the tastes of the orners end is far suncrios to that demended by Jocal decision-rokers. In some cases such qualitativo chanes are brought abous by the spending of private funds. In other insterices poterful individuals, not necessarily wealthy, have a great impact on the location, quality, and nature of cosstal developments.

The behind the scenes role and commication system of poinrul individuals, femilies, or institutions ropresenting them in jurluencing coastal land-use allocations can be so subtle that it is all but. impossible to trace the actual means of intersction (sec Appendix $c$ ). orten it is a single individual, who either through the imact of his personality o\% efforts, that directs a colise of astion on environmontal questions. In othor instances, a Eroup of indivicuals sharing sirilai interests and attitudes tend to set a course of action tincugh a common methot of problem definition and resolution (see Chapter IV E. Greenich). By such goup interaction in the decision-liold, a 
pattern of dccision-making tends to emerge especially in politicelly and ethnicejly honogencous; toms rith txeditionelly slon grouth metes. In many cases this pattern of action is expressed in a "what's good for the tom" articulation. Where such a eroun sxists the mainienance of anicable relations amon the participants is often more irportant to them than the warrer in wilich a particuler problem is resolved. Elected and Administrative Officils in Local Goverwment:

Flected and administrative of ficials in losal govermant form an influential croup who vievs affect the ultinate forn coastal policy may take. In many cases these individuals respond to the pressure brougrt to hear by the eforomentioned groups. But in addition to this they respond to their own and the views of their colleagues on coastal envizomental issues. In short, the actisl decisionmaking process tonds to affect what policy position those key decision-mikers take. Banfield and Wilson have noted:

The function of politics in the smell town is less to resolve issues than be sumpresising them to enable people to get along with each other wile living together in very close personal contact.?

While this may not be necessery in cities, it is clear that issue can be either ninirized, or becone the mediun of exclange in the bargaining process which characterizes local decision-making. In such a process the merits of a given development proposal may be of a secondary importance when two or more factions are contending in the exercise of pores. Two such groups are often the Council and the

\footnotetext{
2I. C. Prnficlis and J. O. Wilson, City Politics (Nive Yorj: Vintage rooks, 1063), p. 25.
} 
Mayor's office. Administrative groups may also groatly influence decision-makers when a given issue involves the allocation of funds to resulve it. When beach ficilities are proposed, for example, the reciezition and public works departments could easily contend with each othex for the construction funds. Such funds might be seen as adding to the stathe of that depertment who uses them. In this case interagency conpetition may motivate these influential bolies rather than a desire to resolve the issue itself. When such a situation occurs Norton Long's game metapior (page 23) is particularly appropriate. MARKGS PLACE;

Local government coastal poljcy is directly related to land resource allncations in a market system. This market system is a major factor in the decision-making field. Governmental policy is expressed legally through land development regulations wich restrict market judgoents as to how land is most prositabiy used. The market place shapes the type and intensity of land usege, while govermiental regulation seens to coordinate this force of change to have it conform with the physical and sccial developnent objectives of the commuity. often these objectjves are not explicitly stated but are reflected in the values of the decision-nakers in goveinment. Such an objective might be to maintain universally high land values throughout the comunity.

The marketplace is concerned with the operation of a price systen as it affects the individual in his attermt to make proritable use of

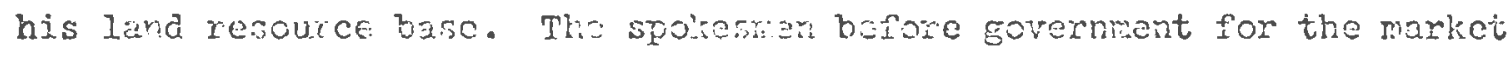
syztem of land allocations are usually reaitors and developers. 
Coastal land, because of its unique location and amenity value, is particularly susceptible to exchange in the narket. The market place can best be described within an economic framework. This framework is based on three general assumptions. These are: (1) that man is a rational being; (2) that man attempts to maximize his self interest; and (3) that prices tend to allocate resources. 22

Two basic economic concepts have been developed from these assumptions. The explanation of these concepts is necessary to appreciate how the market system operates. These concepts are: land-use capacity and the highest and best use of land.

Land-use capacity refers to the ability of any given unit of land resources to produce a net return above the production costs associated with its use. ${ }^{23}$ In the case of an apartment complex land-use capacity means the ability of the complex to generate rents which exceed such costs as amortization, insurance and majntenance. In such a case governmental policy regulating population density has a major impact on the profit the owner receives. Clearly land-use capacity depends on the location of the land in relation to other uses. A coastal residential lot surrounded by the natural environment and bought in an undeveloped state, for example, may increase in value several times if the immediately adjacent land is converted into a golf course, or municipal opan space, thus guaranteeing the present amenity quality

${ }^{22}$ Raleigh Barlowe, Land Resource Economics (Inglewood Cliffs, N.J.: Prentice-Hall, 1958), p. 112.

23 Ibid., p. 12 . 
of the area. Incation of a dump nearby, instead of a golf course, nould have the converse effect.

Highest and best use is another closely related concept. In the economic sense the highost and best use of lind neans the lise that brings tre lichut reburn to the oner, or suciely. ${ }^{24}$ This concept requires a cons ianutjon of land-use civacity and the demand for uses. These uwes terie to chonge throngin tine in response to technology. Coastal. lands which in the fast vere best used for egricultural purposes have shifted in many areas to int nse comercial and industriol uses as urbanizstion occurred. This evolution results from the interaction of supply and derand. Narket denjsions reflect in this interaction of societal volues. Because of the hith amanity value of coastal lands, buyers representing certain lend-uses seck to use this cinaracieristic of the land to their om ecoronic adventage. This desire to vse cosstil lanas is expressed in the terninology of the narket as surply and demand. The supply of coastal land is liruted as a general rule to that lend which is in immedinte proximity to the seas or wich is visuklly linked rith tho ocean. Supply can be defined as the quantity and qualjty of land resources availeble for une. Demand is defined as the frowing need for land and land products and our abiljty to provide for this need. 25

The sumply and dannd function are kept in balance by a pricing

$$
\begin{aligned}
& { }^{2 l} \text { Ibid., p. } 13 . \\
& 25 \text { Ibic. , p. } 17 .
\end{aligned}
$$


mechanisn. Frices a.lzocate probution and cetermine the distribution of resources. Because the supply base for coastal lands is limited in amcunt and lccation, increased denand results in an increased price. This prjec is symoninous with economic value. This value is established hecause the land has utility to the omer; because there is scarcity in supply to comant a frice; and because the omer lolds a concept of futurity. He expacts a returi or satisfaction frow the use of the land. $2 \zeta$

The more the buycr bids the greater the expression of perscnal satisfarticn or expectation of rewum on investnent he js maing. In order to generate this investment return, the porential land-use capacity mat varrant the risk inherent to the purchese. As prices rise so mat the Jand-use crpacity in oroter to make the buyer's irvestment jrofitable. In this manner supereessjen of J.and-uses occur. owners of coastal land-lises, such as single family homes, find that ircreased tayes which are hased on rarket voluations make this typo of use exyersive to maintain. Becuse singlo family residential lise prosuces no revenues for the omex and inced consume his resoures by increased taxes, it can be termed a consurution use. A coastal apartment use, hosever, though resirential in nature is a production use becuse it produces revenues for the ornar.

With the supply of cosstal lands renejuing coustant, yet it in. creasing deman, compesition occurs hetween consurption and produrtion uses. Such.ccisumption uses as recreation areas, open space, and. 
$1: 9$

sincle farily hoines, and institutional uses such as private schools or wild life sarctuaries rust pay increasingly high carrying charges to mintein thenselves. Where denand and prices increase markedy some or these uses change to a hirher and better use as omers capitalize on ibe appreciation of their property values while avoiding tine cash drnily of the canying charees. It is in such a monor that coastal landuscs intensiry as a result of the merket system. It is when chane occurs between land-use types increesing land-use capucity that the greatest profit can be rade.

It is for the local decision-makars to detemine whether this movement towaxd a change in intensity brought about by market activities is compatible with the coastal land-use objectives of the conmunity. Thus the morket place attemipts to influence ccastal policy formation. How decision-makers reconcile the market influence with ecologic consideretions is central to the maintenence of coastal envixomental quelity. This econumic-ecologic dichotomy forws the next inportant factor to be discussed as it influences decision-makers in the decision field.

THE ECONOMIC - ECOIOÁTC DICHOYOMY

Thus far decision-making factors in the decision-field have been discussed independently. The matlet influence snd ecolcyy, however, while seemingly oporating independently of each other share ming characteristjes. By juxtuposing thesa characteristics, the simjaxities and differerces betwen these systens can be illustratod as they arfect. the coastel manederant decision-makine process. 
Kenneth Boulding in an essay ertitled, "Economics and Ecolegy" notes that other than the fact that buth scjences share the same Great etymological root there has been little effort to bridge the chasm between these tro systeirs of viewing the world. 27 Evolution, in the ecological seise, diffors from econonics where evolution occurs in the forn of technological innovetion. Iand forms such as the coastline and the rarine environment peculiar to it are fixed voth in size ani quality when cormared to the rate of technological evolution capable of being employed in the cuastal zone. The slower rate of cinange in nature is easily altered by the impact of technology on the coastal zone.

For econouics the value of innovation to the possessor lies in the utility of the inmovation to him. we return or benerit to the possessor can be measured in dollar values through the maskst demand for tre innovation or in the savings ho receives in applying the innovation to his own operations. Thus, economic evolution is directed lergely by the market. Fcologically speaking, very little is known about why orgenisms evolve except in response to their environment. The sunction of this evolution lies not in growth of dollars, but in survival potential.

In both the ecological and the economic purviev, determining the relation of evolution or technical inmovation to the largcr ecological and economic system is essential in esteblishir the significance of local changes in survivebility aild utility. It is essentiall then to

27 Kenneth Foulaing, "Economics and Ecology," Future Enviroments of North Arrarica (Garden City, N.J.: Natura. History Pross, J.566), p. 
exmine local and notropolitan economies and ecologies in light of their posidion in a regional system.

For tine Jocal dscision-maker freed with increasing demand for more pubite expenditures determined to a large extent by the nuture of the lareer econonic systen; decisions which effect local ecological qualities my be seen as being completely divoiced from the quality of services being demanded. Yet wher etch syston (econonic and ecologic) is viewcà as a paraliel form of organization, each having imuediate and Jong term effects on commity evolution, it j.s clear that the vocajized derands of the economic system is likejy to receive a higher priority when the two systens conflict. When vieved in terms of their relative time scales, eccnomic criteria offer junediate, quantifiable venerit: to the community while the ecolcgical tirs table offers no clear quartifiable value to the municipality. In adaition, experiense with the economic systen j.s vell known, predictable and ofyers uriversally accented rewards. The ecologic system is less well-knom, poorly understook ard holds an unquandfiauje promise for nev payoffe.

When tre econory of the Narragensett Bay region was agricuiturally and sea based, the ecological qualities of an area had immediate im. pacts on the econonic return of the rarmer and fisherman. The quality of the soil, estuary, water supply and timber made the difference between prosperity and failure. It is here man has applied his innovative techriques to special advantage for jncreasing his resouxce base. He has both irproved artificiolity tho quality of the land through the use of techuical innovation such as irrigation and chemieal. apulicution aud increased the cariying caracity of the land's spotiel 
characteristics through the developnent of the urban structure.

Iand values no longer reflect land as a proäucer of basic rcsources in the rorm of crops and livestock. How land is valued for its location. The extent to which dollar values for location can be determined is through such indicatois as proximity to public services, concentration of population, accessibijity to trancporizion, suitability of the Jand for develownert, plublis devard, end rirally, amenity values. In short, land value is currently measured on the basis of spatia] and locetional gulities rather than traditional productivity. In fact as our cities grow, the amenity valus of raw lavd, when corspared to built up areas, often is reflected in the sale orice. This view of land has shrouded its role in the ecological system, aistorted. the impact of the two systems and allowed the local econonic systern to dominte the local ecological systen. Just as cortain land on highway intersections and elsewhere has unusually hich economic value, there are natural areas such as marsh linds and estuaries wiich possass equally high ecolozic value. The ecological rolues of the sea itselt in its narine environments directly relate to market vajues. The ecologjeal quality of shellfish beds, and fjshing grounds is directly correspondent with the supply and price on the market for these products of lani-sea ecolosy. Unfortunately, these sreas are not so readily percejved so as to retain their potcitial in the ecologic system.

In an urban society clustercd around the coastine, as is the Providence metropolitan arca, coastel. land values are rising because proximity to the sea also means propinguity to urvan scrices, and a 
high revenue-proncing cipacity for coastal sites in adition to high amenity value. 28 The natural environment of the coastal zone while giving rise to increases in land valve is not particularly economically valuable in generating revenues if it remains entireiy in a natural. state. Modifications for services such as roads, water, and sewer are requised before oncpancy for residential oi active recreationa]. uses can result.

Whe primary demand for coastal la:td is for residential development. As a result only tine owner of cosstal land receives the benefit of this amenity value which in turn is reflected in both his purchase price and assessed valuation. This pracilce has a paraljel jn the rental fees levied on those leasees of ir upper stories of high rise apartnent: in the city. The cost is based on the assurgtion that the frecdon froin noise, the view and in some cases the cleaner air represent cnvironutal values which are no longer distribuicd cquitably to all citizens; thorefore those that wish to benefit from these anenities should ray a price.

In the tarisfer of coastal proporty as a rosidential comodity in the market systen government has ignored the differences in market values and has talien the position that coastal land sholid ba treated as any othex parcel of land in the commity; and further, that the distribution of the visual and psycholorical assets inherent in the coastline should be subject only to the distributive mechanism of the 
Market determinations of coastal land aliocations. The ecological. system as such has not received strong local government recognition or sanctions. Without adocuate funds lockl conservation coumissions re.main weit in attempting promote local ecologic asareness and preservation.

Thas the rarket recharism can equitably determine the best use of the lara using the urcad commity rajues as critcria is doubtful. Though a founation to comunity rell being, econonic growith or evolution makes litile contribution to the solution of what may be loosely terned "the urban crisis." John Kenneth Galbraith states the paradox in this way:

Econcuic growth does not provide the public services which mark ou procesesion toward a nore civilized existonce and thich are also made necessary by a hicher level of private conswrotion. Economic groirih does not helip those who, becaise of careiless choice of birtholace, on parents, poor egrly environment, absence oi educational opportunity, poor health, rantal retardation, racial discrinination, or old age are vnable to partjcinate fully in the economy and its gains. on the contrary, it makes these discdvantaged nore visible and obscene. And economic Eroth, we have learned does not solve the problerns of our envirominent, and especially our urban environment. On the contrary, it makes these problems infinitely more urgent. 29

Central. City sprayl typificd by the development of Cranston and Warwich, Rhode Island, are clear exanntes of the markets' power to influence public decision-making as mell as its abijity to create a. matter of environmental urgency. Profit maximization serves as the

297. K. Galbuath, "The Clains of the Corranity Against Those of Eccumics," Snecch fron the corierence, "0ur People ard Their Citics," Sponsorcd by Uruan America, Inc. (Hashington, D.C., Sept. 12-13, 1966), p. 2 . 
guide for private economic decisions, and therefore land-use patterns become responsive to changing costs and demands. Land-use patterns subject solely to econonic criteria allow direngence between private costs and social cost: where the djfference is attributable to external diseconomies that cause society to bear the costs of benefits it coes not receive. 30 In short, maxibization of profit is only one criterion to be viewed in devising a rejional polj.cy for enviromental manegement.

In Cranston, for example, large, single family, coastal hores are bejng replaced with luxury apaintments. This developrent indicates that a form of economic Darrinism is at vork in the narket system which parallels ecological evolution. In ecological systems growih in number of organisns occurs until an optimal level is reached. Groith beyoud this level results in over porulation causing stress and shortages whicl restilt in an ajustmat of the number of organisms downward until a balance is again achieved. Fammars have long recognized tris prcblem and have resolved it in domectic aninds enc jn crops through the use of artificial feeds and fertilizers to avoid over erazing and the neea for crop rotation.

On the shoreline the development process of intensification of coastal land use works against the maintenance of low intensity uses such as open space and low density resibential properities because of the casil flow necessary to mect such fixed costs as taxes and amorti-

30 A. K. Campell and J. Eurbread, "Public Policy for Urwan America," Issues in Urban Econonics (Ealtinore, lid.: Johis Hicpins Fress, lofo), p. 579. 
zation besed on the lar'set's valuation of cozstal assets. There is no natural self-edjusting mochanism to control optimal densities.

For the loca]. dasision-maker chared with the task of devising a. connunity-vide land-use strategy it becones increasingiy difficult to balance the explicit forces of economic gain agginst the inplicit viewpoint inhereri in the social values of the community. It is such intongjble goals wich are often sacrificed inorementally across the comnunity as the extemalities become a potent force complicating the jobs of the local decision-makor. Unleass specific environmental and ecologicil analysis of conmunity coastal resources take place land use objectives which reflect the social and ecological values of the conmunity will continue to play a minor role in day to day decisions which are needed as a result, of market influences. Increased understanding of the ecological systen will give decision-makers a longrange standard by which to judge develoment alternatives.

A second demand on the decision-maker rests in assaying the validity of his tools of masurenent in making decisjons. The developer proposing a coastal development schers, for exomple, is able to state in exact terms the benerits of such a plan to the comnunity: specific returns in the form of taxes; high degree of predictability for assessment; and his capital investment in the project as proof that the venture is viable. To rescrve open spece on the coastline, the public decisiun-niker must pay a narket price, expend funds for majntenance annually, forego taxes, and act on the assumption that people will benefit directly from such action and return him to oftice. In eadition, by allocating funds for coastal acauisition he is making a juds- 
ment on the social need for public access to the environmental qualities of the shore. Agajnst this are placed the rocally supported and explicit benefits of allocations of the same money for such demands as education, welfare and u higher level of public sarvices. Even if public action in coastal environmentel preservation is only to increase public access through the acquisition of rigits of way on the shore, es in the Jayjing out of streeti; legrl entanglements and suits for inverse condenation awstis meke this a pour second alternative. The accelerating detrioration of the coastal envirconment demonstrotes ingt tha advocates of narket criterit for land-use choices have prominence. It is equally clear that the handling of the externglitj.es of such market-oriented land-use decisions have been either overlooked or badly handled bj local decision-riatieis. The granting of public sanctions for develcpment of coastal assets in return for tax dollars has an enomous potential for overwhelring the local decision-maker because of the pressures for increasing expenditures in existing public services. The public, in effect, lives with the enviromental consequences of such trade off's. Once coastal landuse patterns have been established by such a process there is litile social recourse for improving the quality of such a decision, regardless of the sacrifice of ecological resources. In most instances such decisions are final.

Local decision-makers have yet to maintain a broad scope of reference in gamering information for coastal land-use decisions. By maintaining an economic-ecolorical balaice in the weighing of informition he will. not be overwalned by the demanus of economic 
"reality" in expense of less obvious, but no less meiningful aesthetic and ecologic cousiderations inherent ir environmental preservation. EXIOTING JURTSDICT YOIS AND COTIROLS

Before any locol decision-maker can act intelligently toward the formulation of a policy toward the use of the coastal zone in his municjpality, he rast be aware of the distribution of jurisdiction and controls which form a netrork confining the scope of his potential activities. This network of jurisdictions and controls constitute a constant factor in the decision-field.

Mr. GIenn Kumekawa, Planning Director for the City of Warwick and one of the original initiators of the Natural. Resources Croup as a potent force behind the establishment of the Department of Natural Resources in the early $1960^{\prime}$ s and more recently, the Governor's Techuical Comittee on the Rhocie Island Cosstal Zone, sumrarized the legal and administrative organization of the use of Narragansett Bay in this way: ${ }^{31}$.

"Two major types of jurisdiction and controls are presently exercised over Narragansett Bay. They are:

a) territorial controls

b) functional controls, or

c) a cowivination of the tro.

These include:

1. The jurisdiction of the Federal Government over "nevigational vaters" through the coast Guard and the implenentation by the Coast Guard of the Boating Act of 1905 as vell as construation

31 Glenn Kumelawa, "Toward tine Formulation of a Regulistory Framevork of Use of Itarragansett Bay" (1567), A study report vo the Natural ksaurces Group for their study, Report on the Adninistration of Narraransett eay, Jan. 7, 1559. 
and navigabic waters throuet the Corps of Arny Engineers.

2. The tcrritorial jurisaction of the stats of Rhode Island over all Norragansett Bay through the "ooctrine of terititorial waters extending one marine league of the mean high water" (appisominatcly 3 miles).

3. Jurisdiction of various agencies of the state of Rhode $\mathrm{I}$ sland for different furctions:

a) Shell fishing and fishing under the Fish \&: Game

b) Pollution of Waters by the State Health Departirent

c) Use of hydrofoils or other means of transportation by the Public Utilities Division

d) Construction of Navigation by the State Division of Harbors and Rivers; E.rd since 1967

e) The filling of Marshlands by the Deyartment of ratural Rescurces.

4. The jurisdiction of locel commanities adjacent to Narresansett Bay with their porers of zoning and licensing. In addition, such nunicjpt. agencies as the Port of Providence Authority also excrcises certain powers.

5. Property rights of individual. owners of land and parcels as it extends off shore through "riparian rights".

In addition, dominant land uses along the Bay exert considerable influence on existing and potertial uscs of the Bay without statutory jurisdiction. For examle, the Navy instaliation ai Quonset and Ncrport vill exert a great in. fluence as to what can and will occur in Nerreganseti Bay because of what may be temed the "negative jurisdiction" of the threat of closing these bases. (See A.ppendix C.) Simjlarly, The University of Rhode Islend, with its major investment in the oceanograniy and Narragansett Marine Laboratory, will exert great influence over the uses of the Briy.

Clearly, while regulatory arencies provide controls over such problem; as pollution, the controls are so speaific and sermental that rot even jarger functicnal categories of the Bay's user aro effectively controlled. These categories include: 
a) Narragansett Bay as a pori of entry or as a shipping lone.

b) Narragansett Bay as a recreational and/or conservation area.

c) Narrafansett Bay as a drainage basin both of surface drainage as vell as for iniustrial anci residential effluents.

d) Narrasonsett Bay as a source ot extractive resources, fishing aird shell fishirg.

e) Narraginsett Bay as a deteminant of land use patterns or adjacent land.

f) Nariguansett fay as a potontial source of water supply."

What Kunekawa has suggested can be portrayed graphically in the form of concentric squares over which is put the functional controls of special interest agencies. These are depicted on chart $A$. Interaction of Factors in the Decision-field:

Factors in the decision-field iriteract in a wanner peculicir to each municjpality to be studied. While each factor is responsive, to some degree, to regional and national trends, each in its om marifestations react with the other factors on the local level to effect coastal policy formulation. Tro of these factors, the econowicecologic dichotony, and jurisdictions and controls represent passive influences in the decision-field. While their presence affects decision-makers, they are unrepresented by sponecmen and are themselves subject to small incremental change, if historic patterns hold true. PJanning, politics, and the marketplace, however, are active factors in the decision-field. Each is represonted by spokesmen and. each tends to offset the rull impact of the others. The rarket factor carries behind it perhops the greatest institutionalized foree. The maxlet system of exchange acts as a mino ornoming force in society for it defines roles and procedures between individuals and institu- 


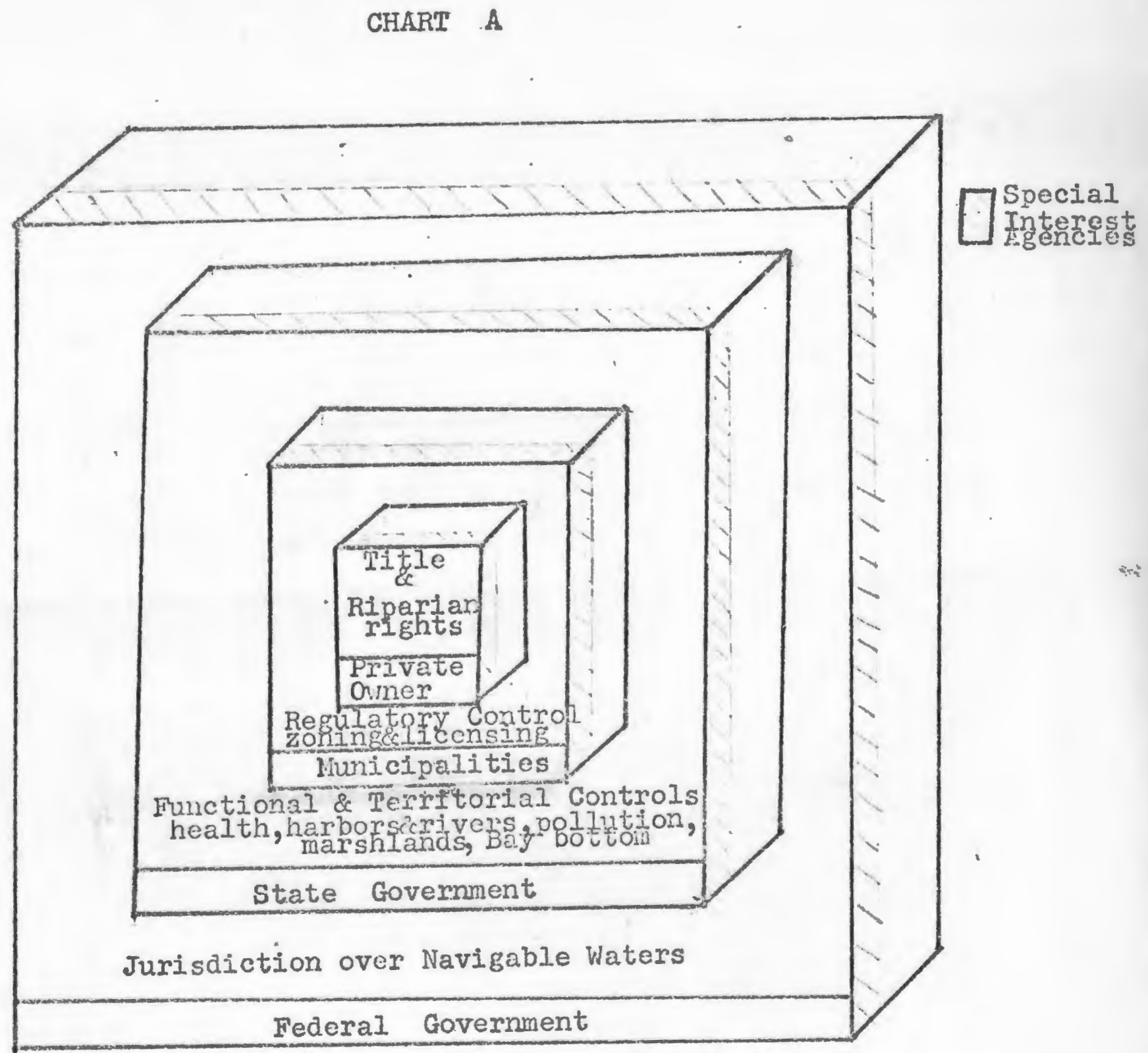

Jurisdictional Controls Affecting

Narragansett Bay Coastal Lands 
tions involved in commerce and economic development activities. The market place has a pervasive inflnence in the degree of functional specialization evidenced in the major institutions of the comnuity. These specializations are an impoctant characteristic shaping the form of the decision-ficla.

Poljtics in j.ts jnstitutionalized form of government reacts to the market factor through sanctions and regl:lations. Interest groups presert viewpoints which reflect certain values. These values are enuriciated in the hope that they will be reflected in Eovernrantal policy which stimalates or retaids the marketplace. Though suck enumciated values may be directly in opposition to each other (as in the case of the developer seching to increase coastal land use capacity through filling of marshes while the conservation conmission seeks to retain such a low intersity use), each is responding to the influence of the market factor.

Planning, unlike politics and the market factor, carries behind it no institutionalized force. It can be both a reactive or initiating factor in the decision-field. It seeks to inrluence decisionmakers as well as the market factor. When forcefully articulated in the decision-field it can harness the market factor and political groups to accouplish community development objectives. In most cases these objectives are defined by the planning function. When veakly presented, spokesmen for the market factor attermt to negate or direct the irmact of the planning factor to sanction their point of vicw. Thougin each of these three active factors offset one another, their relative strengths and wealnesses vary through time. Because 
of their institutionalized besis, the market and political factors are likely to vary least in theii position in the decision-field. Planning, whose efrectiveness depends greetly on the organizational and professional corpatence of the furction, is subject to significani variations in its relative influence in the decision-tield. When viewed historicallv, however, the inpact of planning is increasing. Because these three ective factors are the doninant forces in the decision-field, they will be used as a framswork for discussion jn the analysis in Chapter IV of coastal envixconmental policy formulation for each of the four municipalities in the stucly area. 
III

HISTORICAL SETTTNG

Cranston, Warwick, East Greenwich, and North Kingstown, Rhode Island 
The study Setting:

The seventy miles of shoreline composing the West Narragansett Biy coastal enriroment offers a full erray of rian's activities on the waterfront. Sore of these activities are the result of historical trends wille othere have been the result of direct and indirect Eovernisitnl policy on either the Federe]. Stete or local level. Each city and tom governent is approsching the management of its cozstal cesources from a different point of vich. Lend use patierns ectabljshed in the most urbanized areas, however, are now beginning to be rupeated in less urbanized parts of the study area. Taken as a whole the process that is occurring in the Narragansett, Bay region may reflect in a limited area what is occuring along nur cntire national coastal continenta]. voundary.

Together: these four towns and cities represent $20.2 \%$ of the State's population (1965) and a total growth rate averaging $14.5 \%$ above the average growth rate for the Providence-pontucket-larnick SNSA for the 1950-1965 period and 15.4\% above the State increases for the seme period. Correspondingly the resjdent civilian labor force in the study area increased $15.5 \%$ over the state totals for this period. While these selected indicators suggest the growing pains which these torns and cities have experienced over the last 1.5 years, it is necessery to have a longer historical. perspective for each tom in order to understend the evolution of coasta.l land use changes in each

\footnotetext{
Irited Stutes bureau of the Census, Sonciaj Consus, October 7 , 1965.
} 
municipality as a platform for present and future environmental policy. The following pages outline the historical development of these municipalities, the character of present waterfront land usages. The potential for governmental change is explored in detail in Chapter IV. The sum of these configurations set to a large degree the pattern of development and future of over 1/4 of the entire Narragansett Bay area. By their activity and evolution these communities will influence by their decisions a far greater area than their actual jurisdiction might suggest. 
CRANSTION

Hiscorical noveloment

From the earliest duys of Rhode Islana history it has been Cransiton's proximity to Providence rather than to the sea that has stirnulated its population grouth and intense development. ${ }^{2}$ Early settlement occurred on the Pastucket River in the 1630's because it was a convenient middle poirt between the hub of the Providence Plantations to the north at the mouth of the Blackstone River and the more renote outpost to the south along the Bay. By 1774 the population had grown to 3.884 souls who were employed in vurious agricultural and small locally oriented manufacturjng concerns. This number held stcady untjl the $1820^{\prime}$ s when the cotton boom dorninated the econony of the area. Imnigrants to the tow during the centennial betreen 1820 and the nineteen hundreds were the primary source of population growth. Mills exploited this new source of labor. Thase impoverishod people represented many nationalities.

The Erglish appcared between 1820-1800, the Irish and German. between 1840-1880 and the Italiens between 1900-1915. To this day there is a strong representation of those of Italian descent in the Cranston Government. By 1910 the population had silelled to 21,000. This figure was more than tripled by the 1960 census. The year 1939 sav a doubling of building activity over 1938 as the initiation of

2. General historical backeroma for Cranston is from the following sources: J. Earl Clausan, Cranston--An Historical Sketch (Proiduence: T.S. Hemond Co., 1904); Crenston Bicentenrial 1754-1954, Cranstor: Bicentennial Cormitten, 1554 . 
the war stimulated rapid development in such previcusly distinguishable villäe nuciei or Eügtwod, fiden Park, ard Auburn. Develonment since has occuxred in a predictable yet unplanned manner os large grid patterned slibuivisions filled in the open areas between these early villages unifying them by strip conmercial develoment aiong the mijos: street networks. The present focus of devilopment has shifted, by necessity, to West Cranston, the last renining reservoir of undeveloped space in the city.

Ciransion's economic backbone has always been and continues to be its manufocturing enterprises which, when compared with other citjes in the state, are lareer than average in erploynent size. Diversification in retailing etriployers wich occurred during the rapid gruth of the corrounity during the last twenty years has accounted for les; of a dependence on the traditional textile industries than other Rhode Island cities. Despite the advences in economic development that have occurred as a result of the nodernization of old firms as we].l as the establishnent of new industries, Cranston's government has beer hard pressed to maintain municipal services without a rapid increase in the property tax. The tax rate in 1960, for exanrle, was $160 \%$ over that of 1950 .

The demand for new housing is expected to continue well into the $1970^{\prime}$ s with 4,300 new dwelling units projected reguiring 1, 100 to 1,400 acres of land to support an estimater population of 84,000 in 1975 (an annual increase of 1,100 )..$^{3}$ Most of this development is 
predjeted to occur in the West Cranston area. The highly urbanized character of the City has elready been vell established and promises to intensity. Average gross density stands at 3.9 persons per acre as of 1955 with a projected gross densjty of 4.6 persons per acre in 1.975. With the comletion of Rt. 295 as a circumferential route arouk Providence, much industrial. and comercial development can be expected to occur in the Western part of the city. Indeed several key nembers of the City Adminjstration as vell as local realtors in viewing this poiential see the undeveloped land to the west as the City's major resource and are fostering plans for a 600 acre industrial park, commujty shopping, school and recreation facilities. Seven and a half million people reside within a 75 mile radius of Cranston. Plans underway prescntly encormass 1,360 acres where Rt. 295 passes into Cranston. 4

Character of Waterfront Irand Use

Land-use patterns for the 3.5 mile coastline of Cranston were firmly entrenchea by the year 1891 and have changed little since. With the improvement of roads between Providence and the Pawtuxet. River durjng that decade the outcrompings of land which rise 35-40 feet over the shoreline were soon sold as suburban home sites to wealthy Providence residents. As the Figevood section of the City developed into one of the nore fashionable residential areas around the Bay, the coastal land usage vas locked into a single fanily residential

${ }^{4}$ A Develcrint Concent for riestern Crension, City of Cransion

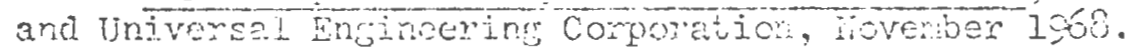


pattern intcrspersed with yacht clubs and masine criented facilities. Unljke the estates of Newport or the large salt water farme of Bristol, development occured in relatively small blocks of land with large individual houses sitod on parcels scldom exceeding $3 / 4$ of an acre in size. Public access to the marine envirorment is available at onjy 3 points: the Providence-Cranston boundary where a boai launching site is located: the Still House Cove Reservation which offers a public beach on 1.9 acres of land; and the Fawtuxet River area, a narron yacht anchorage. All three areas offer litile in the way of scenic amenities because of their size and upkeep. Water off these facilities is presently classified SD, the fourth lorest of five classifications, making the area unsuitable for bathing, fishing or wilolife habitat. The Partuxet River which dominates the Cove amea is Class F. (ivuisance, unsuitable for most uses.) $)^{5}$ Despite the relatively low quality of the water and public facilitios, the visual space that proximity to the Eay offers has kept the Edgowood section of Cransion, and specifically the land which abuts the shore, at a continususly high value in relation to more inland parcels. 6 As densities across the city jnerease, the visual impact of the marive environment has made the demends for these older established coastal homesites a significant factor in the evolution of man's intensifying impact on

${ }^{5}$ Department of Health, Division of Watcr Pollution Control, Map. Present Classification of Water Cuality--Sources of Pollution, State of Rhode Island, 1967 .

Goffice of Asscssor, City Hall, Cranstion, R.I., 1.659. 


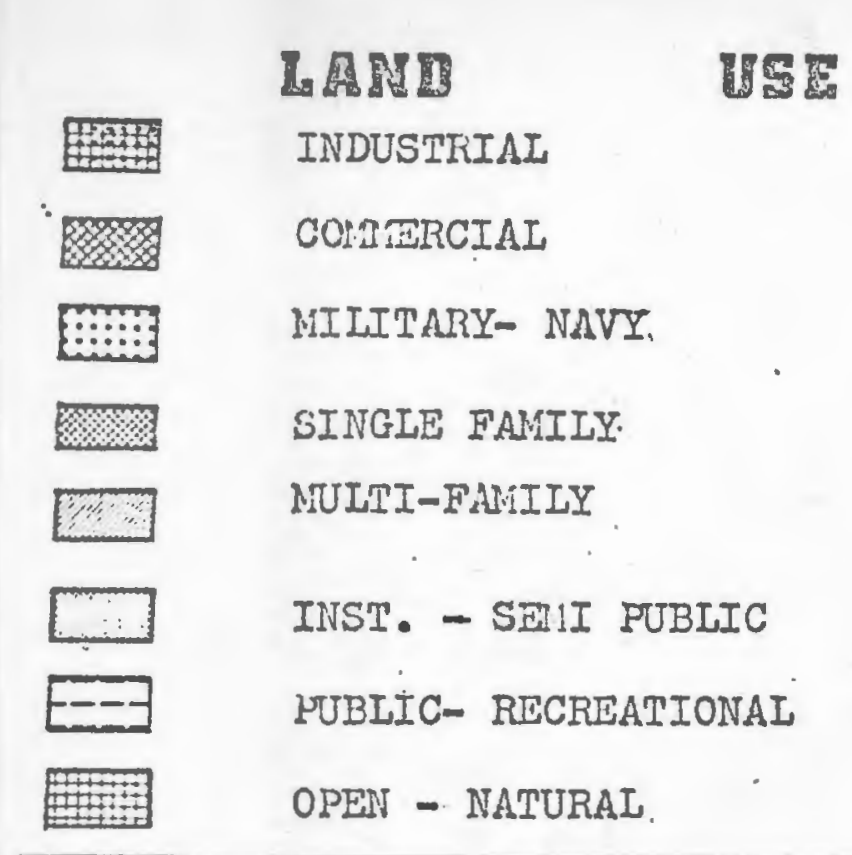

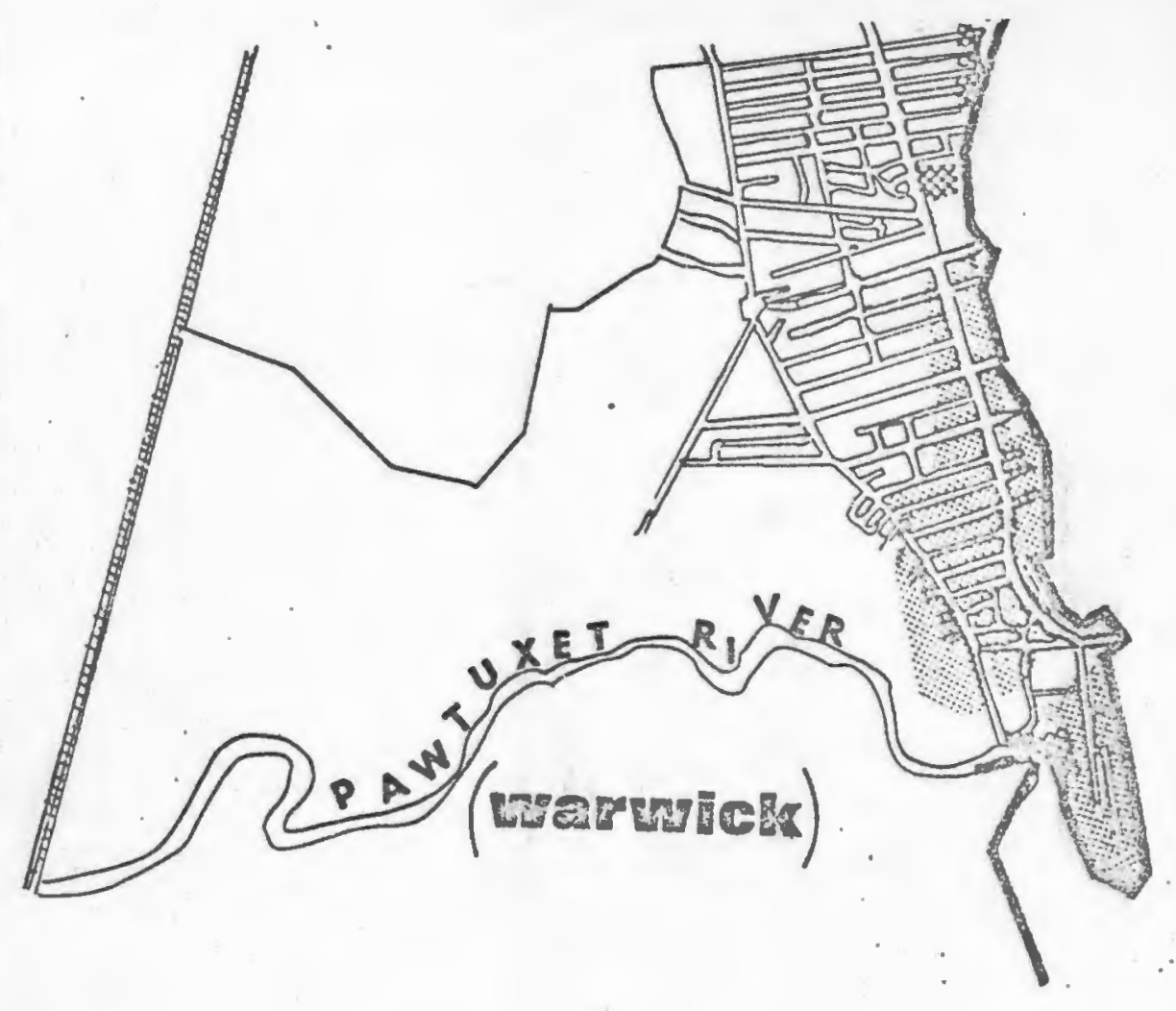

CRARSTUN RI.

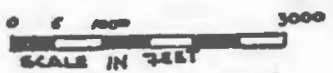


the seascape. Map II illustrates the configurations of land use in the coastal area. 


\section{WARWTCK}

\section{Historical neveloonent.}

There is a marked rescmbluce between the doveloprent patterns exhibited in the evolution of Cranston into one of Rhode Island's largest cities and those undergone by Warwick, Eaci originated as a small sctilement in the 1630's alonis the Pawtuxet River which soparates the cities. Each had inland villages that slowly grew together as urtaniztion occured creating oldei comercial centers amid extensive areas of strip comercial development. Both experienced an influx of immigrants of the same nationalities during the same periods. Fach city has experiencea the same evolution in their economic base throush the turn of this ccntury ond un to tre First World War. But as Cransion has looked to its western extremjties as its major Jand resources for the future, Warwick seeks to balance its development focus geofrephisally for three principle reasons: 1) the tow possessed 39 miles of varied coantline including ocean frontage, bays and coves, which offer sites for a variety of uses from heevy injustry to wildlife sanctuaries; 2) the mid-city area dominated by the Green State Airport has provided an intense focus for a great number of service industries; and 3 ) the western section of the city, dominated by the Upper Pavtuxet River: basin, has been oriented toward Route 95 which has stimulated the development of major regjonal retail shomping centers which serve the rapid suburban growth that has affected the city in the last 20 years.

The urban sprawl which eccountea for a loss of $9.8 \%$ of Providencs's populat:on during the first five years of this decede also accoundea for a $13.3 \%$ increase in Warwick during the same pericd. The city 
expericnced a phenomenal $47 \%$ increase in the number of dwelling units between 1950-1950. With a projecteil population expected in 1980 of 120,000 the city will have gained 51,400 residents over a 20 year period. The 1960 census of housing documented the suburban character of the city by finding that $9 x \%$ of all its dwelling units are single detached structures. 8 This cmphasis in development has resulted in an average density per gross acre of 3.4 persons which will increase to 5.6 persons as the city approaches the 1980 projection point. With the added emphasis on the development near the airport, the growth of large regional shopping centers in Western Warwick, and the impact of the conpletion of Route 295, the continuation of this building boom can expect only to be influenced by New England and national economic fluctuations. With a history of increases of retail sales between 1562-1067 of 11]\%, surpassing the next Rhode Island city by nore than $84 \%$, it is clear that Warwick's economy is growing rapidly. 9 Character of the Waterfront Iand-Use

The abundance of shoreline in Vamick makes the City's window on the bay one of the comiunity's greatest resources. The single family residential patterns wich dominate the city have been well established along the coaste]. zone in varying densities from estates controlling large expanses of frontage to converted seasonal dwellings on one-

7 United states Bureau of the Census $1,60$.

Wajwjck Master plan: Recreition, open Space and Watorfront, Warwick City Plan Department, Adopted by Council 1064, BA.7.

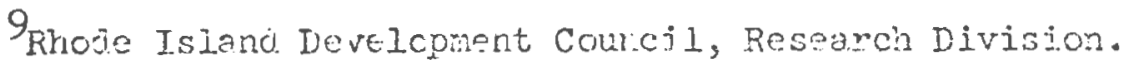


eighth acre lots. Between 1959-1063 permits for marinas and marine construction increased the available boat slip facilities by more than 1,000. In 1963 more than 1,300 boats moored or storea in Warwick resulted in an income of $\$ 163,000 .^{10}$ Sales attributable to the shorefront avergged better than $\$ 1.2$ million in each year from 1960-1962. Having exporienced severc hurriane damage in 1938 and 1954, several areas (e.ध., Conimicut Point) which vere previously resjdential in nature have keen returned by the devastation to their natural setting. Separated from the City by Iast Greenwich, Goddard Memorial State Park occupying 172 acres and 8,100 feet of natiural shoreline provides a regional recreation area which is supplemented by many smaller facilities on Greenwich Cove and on the Upper Bay area abutting the City. As the prossure for available space conirues unabated, rulti-family housing units are beginning to supplant many of the smailer older units near the pawtuxet Cove Area. In the nost sceric area such as Warwick Neck and Sandy Point high quality subdivisions dominate the coastal land use patterns. Map III illustrates the wide variety of coastal land uses. Chart 3 denotes the relative front footares these dominant land ures represent.

10 Warwick l'aster Plan: Recreation, Open Space and Water Front, Warwick City plan Depaitment, Aopter by Council 1964, p. 52.

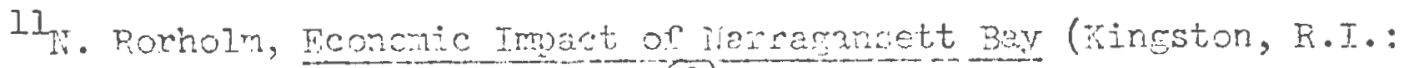
Agricultural Expriand Station, 1603 ). 
LA Ant

INDUSIRIAL

- COIMIRRCIAT

MIIITARY - NAVY

SINGLE FARILY

MULTI - FAMILY

INST. - SIMI PUBLIC

PUBLIC - RECREATION

OPIEN - NATURAL

\section{US舆}
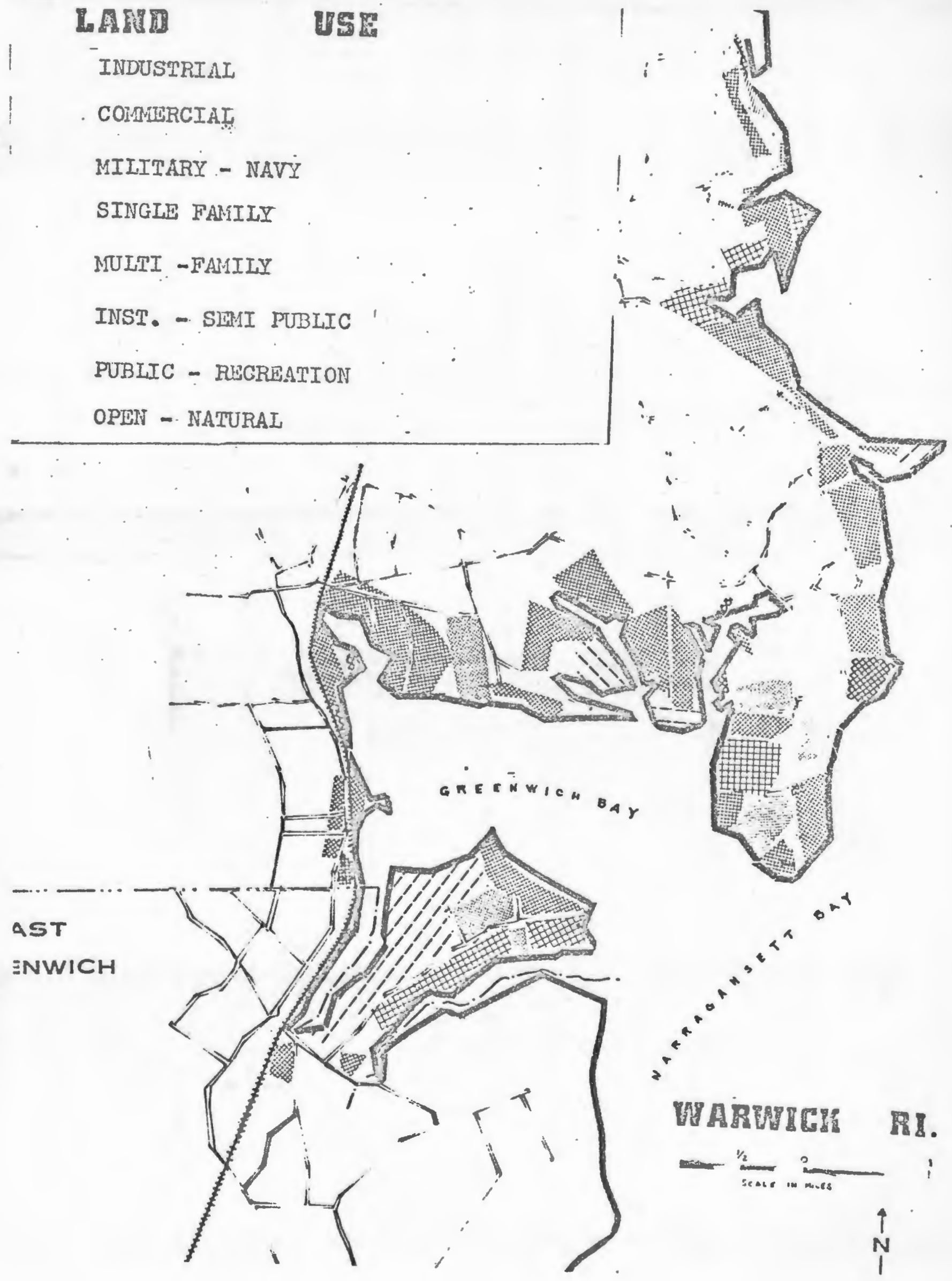
EAST GREENWICH

Historical. Development

The abundance of ground water and game that originally attracted the Narsagansett sachens to the forested hills overlooking the southern extension of Greengich Bay did not cscape the notice of early English settlers to the region. In 1676 the pionecrs esteblished a heavily fortified trading center in what is now domtom Fast Greenwich. Since that time the growth of the town which separates Kent and Washington counties has made up in quality what it has lacked in numbers. The secluded harbor with easy access to the coastal trading routes developed into a major Rhode Island port for continental and jnternational shipping concerns carryirg sugar, molasses and rum as well as the "Black Wealth" of Africa. Many of the sea captains built homes along prestigious Kings Street wich overlooks the Bay. The wealthy character of the town has been maintained through the years as porulation grew frora 240 in 1708 to 3,842 by $1890 .^{13}$

Duxing the last two decades of the ninctcenth century East Greenvich extablished itself as the State's leading producer of scallops and other shellfish, and since that time has maintained a strong orientation to the sea in growth of their boating industries. The small population has historically been sumported both by the tom's dependence on the sea as well as tradjtional manufacturing pursuits. Many or the older industries were located near the water-

13 liartha McParland, The History of East Greenwich 16́77-1950 (East Greenwich Free Library Assoriation, 1000), p. XT. 
front below the sharply rising hills which separate the harbor area from the western section of the city which is dominated by the Maskerchugg River basin emptying into the innermost extension of Greenwich Cove.

Today the local economy is anchored by the Bostitch manufacturing plant which employs over 700 residents. Other major regional employers are the Quonset Naval installation which accounts for $21 \%$ of the local labor pool, Browne and Sharpe manufacturing, also in North Kingstown, and the twenty manufacturing industries of the town which produce metal fabrications, machines, food and beverages.

A town of only 16 square miles, East Greenwich has attracted many residents with high incomes. $15.1 \%$ of the families have incomes of $\$ 10,000$ or over as compared with the state average $11.7 \% .^{14}$ This distribution of income is reflected in the quality of the housing that is being erected to meet the demand of the rapid population growth which began during the 1950's. Building permits show that the average dwelling unit being constructed in East Greenwich is worth $60 \%$ more than the average dwelling unit under construction across the state. ${ }^{15}$ of the four cities and towns in the study area, East Greenwich has experienced the most rapid growth in population. Between 1960 and 1965 population increased $34.9 \%{ }^{16}$ Chart $2 \mathrm{~B}$ summarizes comparative

14 United States Census 1960--25\% sample. Rhode Island Development Council Research Division.

15 Rhode Island Development Council, Research Division. 1965 . United States Bureau of the Census, Special Census, October 1, 
development in the toms and cities study area. By 1980 it is projected that population will be more than 50\% above the 1965 figure of $8,228.17$ Density based on the 1980 projection will be 8.1 persons per acre conpared to 5.8 persons density per gross acre in 1965 . The Character of the Waterfront Land Use

East Grcenwich's coastal zone on Greenwich Cove has been dominated historically by intensive marine oriented land uses. The expansion of the downtown area of settlenent through the years has accounted for a large number of older structures present in the mixed land use pattern of the shore area. With the central business district within $1 / 4$ mile of the shore, many of the historical developmant patterns of residential and manufacturing uses still remain as delapidated relics of the past, unfit for the demands of the twentieth century. The first 2,500 feet of coast in the northern most shore within the town is devoted to intense marine recreation activities: boat yards, yacht clubs and docking facilities. Uses become less intense moving up the bay with the final 3,300 feet being utilized as the approach to the municipal dump winch is located at the mouth of the Maskerchubb River drainage basin and Greenwich Cove. The remaining 4,700 feet in the mid cove area of the 2 mile coastline is devoted to the outlet and leaching fields of a municipal sewage treatment station, a public boat launching site, bait shacks, and older multifarily housing overlooking the Cove.

The single dcrainating cultural feature that has isolated the

17 Rhode Island Staiewide Transportation and Iand-use Plenning Program, ledium Projection from Report No. 7, Dec. 1566. 
shore area from the rest of the town is the Penn Central railroad line which traverses the entire coastline of East Greenwich. The rail line varies in its proximity to the high water mark from distances of 750 feet in the center of the downtown area to as little as 20 feet on the northern Warwick-Greenwich town line. Despite the disheveled and dilapidated condition of many of the structures in the coastal area, the overall environment of the area has a high amenity value. This amenity rests in the character of the opposite shoreline, Goddard Memorial state Park, which acts as a natural backdrop to the harbor anchorage. The Cove itself is more than 1,300 feet wide in its farthest point from Goddard State Park. For those on the Greenwich side of the harbor the presence of this natural area adds measurably to the view of the harbor. For those viewing East Greenwich from the Park itself, the haphazard development and filling of the town's waterfront marks an abrupt end to the amenities of the park area. 


\section{LAND USE}

\begin{tabular}{|c|c|}
\hline 표료 & IIDUSTRIAL \\
\hline 28. & COLEREIAT \\
\hline E: & MILITARY - MAVY \\
\hline$\square$ & SINGIE. FMIIIY \\
\hline & MUITI - FAMILY \\
\hline Li. & INST. - SWMI PUBLIC \\
\hline & PUBLIC - RECREATION \\
\hline Fis & OPEN - NATURAI \\
\hline
\end{tabular}

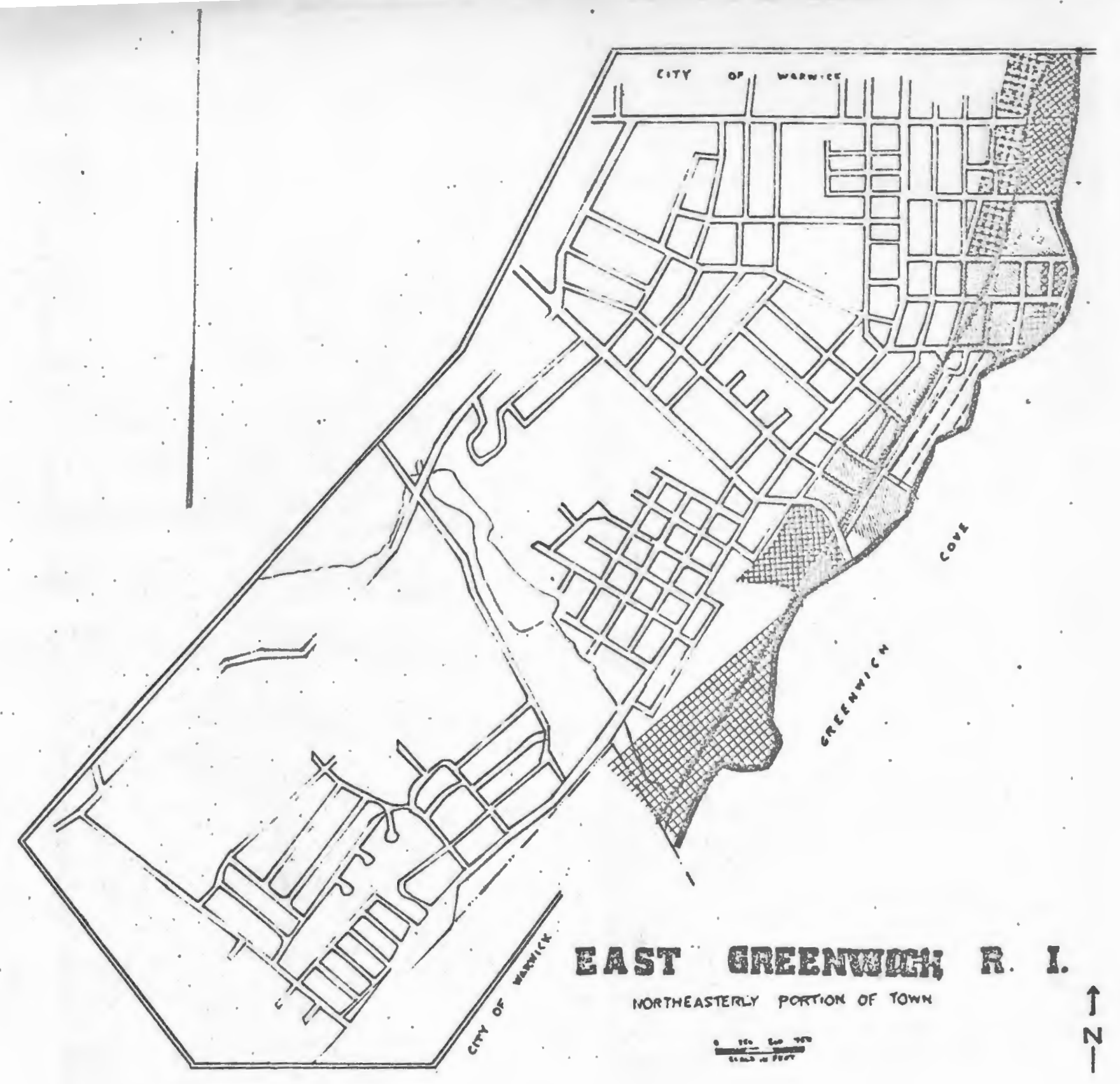


NORTH KINGSTOWN

Historical Development

of the 70 miles of shore line in the study area $41 \%$ (29 miles) fall under the jurisdiction of the town of North Kingstown. Like East Greenwich and Warwick to the north the town (originally) developed because its harbor offered a combination of resources .which were essential to early settlers: safe access to and protection from Narragansett Bay, the major transportation link between trading posts; a rich source of shell and fin fish; and easy proximity to fresh water, forests and some of the finest agricultural lands in the entire bay region. From the original settlement in Wickford cove established in 1639 secondary development occurred in the form of agricultural villages to the west and south. ${ }^{18}$ Their names of Slocum, Allenton, and Saunderstown honor some of the pioneering families whose presence helped shape early Rhode Island history.

For the next two hundred years development in North Kingstown mirrored the economic trends which shaped the New England region. Agricultural trade both to coastal ports such as Boston and Providence and internationally to the West Indies and South America sustained the town until new technologies in the 19th century established the steam ship as the most economical means of comercial transportation. The stability of the area's textile and water oriented industries, however, provided the impetus required to maintain a slow growth rate

18 Daughters of the American Revolution, Pettaquamscutt Chapter, Facts and Fancies Concerning North Kingstown, 1941. 
In to the twentieth century.

Within the last thirty years the contemporary pattern of both coastal and economic development for the town has become manifest. The Navy, recognizing the strategic location of Narragansett Bay on the eastern coast as well as its natural advantages as a training area near two major urban areas (Boston and Providence), acquired nearly 6,000 acres of the 44 square mile township to establish in 1941 the Quonset Naval Air station and the Davisville supply depot. With this acquisition of large farms just north of Wickford Harbor extending to well beyond Calf Pasture Point, 4.6 miles of coastline was converted to military use. The displacement of the original seventy residents of this area has since been offset by the growth of this naval installation to a compliment of over 14,000 military personnel and an industrial plant which employs over 5,000 civilian workers contributing to the region in 1967 an annual payroll of over $\$ 77,000,000^{19}$

The sharp decline in textile manufacturing enterprises coupled with the growth of machine and service industries in the state's economy has again placed North Kingstown in an era of substantial change. 20 The relocation of Brown and Sharpe Precision Tool Company from Providence to a modern plant in North Kingstown in 1961 provided the second column of economic support for the town.

19U.S. Department of the Navy, stockholders Report, Newport, R.I., 1967.

20 Arthur D. Little, Projective Economic Studies of New England, 1964-5, Table A-4. 
Pleasure boating and seasonal homes are the third pillar providing economic strength. Of these three major influences, it can be effectively argued that it is the proximity to the sea which has been the underlying determinants in these historic and contemporary developments which account for a $75.5 \%$ increase in population to 26,000 between 1950 and 1968 and a 221.7\% increase over the decade prior to 1950.21 The bulk of this added population has distributed itself in the northern part of the town near the Navy installation and the Brown and Sharpe plant where there is quick access to Route 95. The continuing improvements on the southerly extensions of this interstate highway have reduced commuting time to major areas of industrial employment in the Warwick-Cranston-Providence area to not more than 30 minutes.

It is clear that the residential growth of North Kingstown can be attributed to more than the town's economic base. The still rural environment of the town with an average gross density of 1.2 persons per acre and the easy access to both the regional shopping and employment centers to the north and the recreational areas to the south, have made North Kingstown's historical advantage of geographical location a still potent force behind the rapid suburban development that is taking place. Character of Waterfront Land Use

Compared to the other towns and cities discussed, the waterfront

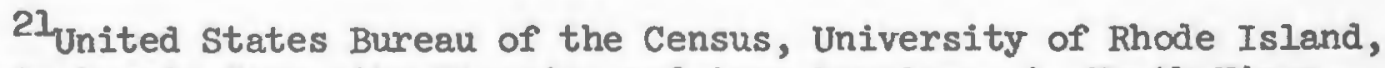
Curriculum in Community Planning and Area Development, North Kingstown Report, Fall 1968. 
development patterns of North Kingstown are of low intensity and irregular proportion. While comercial and recreation orientations dominate the coastal cavironment in East Greenwich in such intensive uses as marinas and yacht cluos, the extensive shoreline of North Kingstown remains in low donsity single family housing or in its natural state except the two areas of major activity, Wickford Harbor, and the quonset Naval facility. Map $V$ indicates the existing land use (1969) of the shore line of the town. The large uninarked areas reflect land which has been left undeveloped. Chart A summarizes the distribution of land uses for the town's coastal areas. With the exception of three cores, one of which is located in the Naval installation, the lone shoreline offers poorly protected anchorages thus discouraring comercial development of marine oriented activities. The gently rising coastal escarpment, hovever, affords many areas of easily developed land for residential purposes. Those areas that have not yet developed are either presently inaccessable, low, held in large ownerships or held by institutions. Such a configuration of restraint has not proven in the past to be a Iong lasting inkibition to developers as the pressure of suburban development continues to rise. 


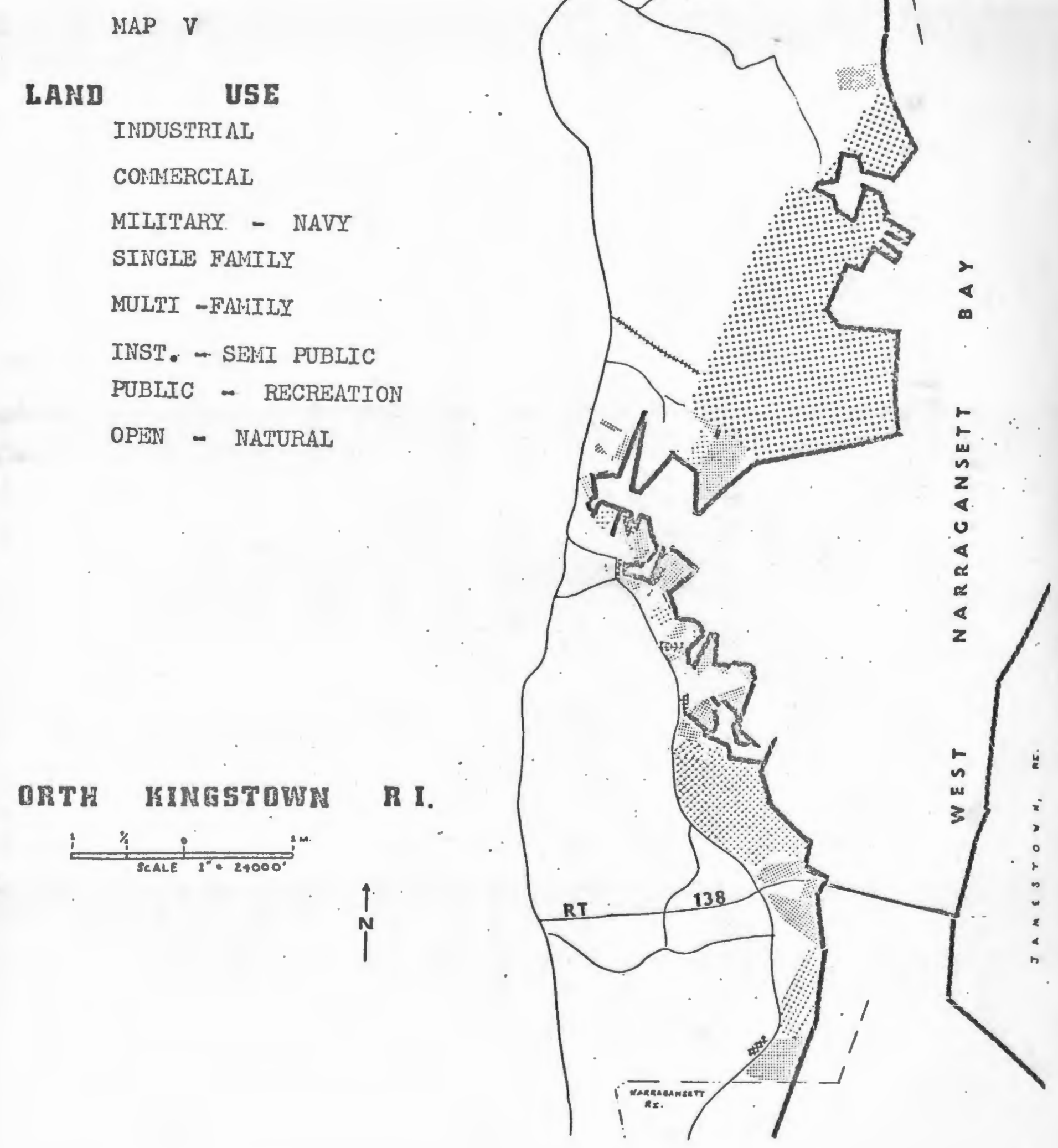




\section{CHART B}

Comparative Development of Study Area Municipalities

\begin{tabular}{lccccccc} 
& $\begin{array}{c}\text { Total sq. } \\
\text { miles }\end{array}$ & $\begin{array}{c}\text { Land area } \\
\text { in sq. mi. }\end{array}$ & $\begin{array}{c}\text { Inland water } \\
\text { in sq. mi. }\end{array}$ & $\begin{array}{c}\text { Pop. } \\
\text { April } \\
1960\end{array}$ & $\begin{array}{c}\text { Pop. } \\
\text { oct. } \\
1965\end{array}$ & $\begin{array}{c}\text { \% of } \\
\text { Change } \\
1960-65\end{array}$ & $\begin{array}{c}\text { Density } \\
\text { per gross } \\
\text { acre } 1965\end{array}$ \\
\hline $\begin{array}{l}\text { Cranston } \\
\text { Warwick }\end{array}$ & 30 & 28.6 & 1.4 & 66766 & 71913 & 7.7 & 3.9 \\
\hline $\begin{array}{l}\text { East } \\
\text { Greenwich }\end{array}$ & 16.7 & 34.9 & 14.2 & 68504 & 77637 & 13.3 & 3.4 \\
\hline $\begin{array}{l}\text { North } \\
\text { Kingstown }\end{array}$ & 16.6 & .10 & 6100 & 8228 & 34.9 & 5.8 \\
\hline
\end{tabular}

Sources

Area Measurement Reports, GE 20, No. 41 U.S. Bureau of the Census, April 1967.

Rhode Island Development Council - Research Division

Spec. Census, Oct. 7, 1965, U.S. Bureau of the Census. 
CHART C

Coastal Land-Use West Narragansett Bay (percentage of coastal land-use for each town) Based on primary land-use within

$\frac{1}{4}$ mile of high tide mark

\begin{tabular}{|c|c|c|c|c|c|c|c|c|c|c|}
\hline . & 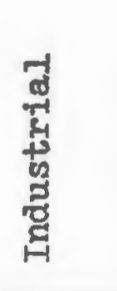 & 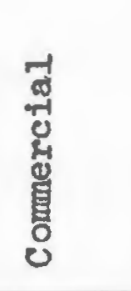 & 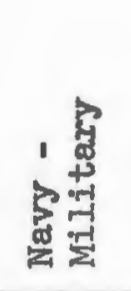 & 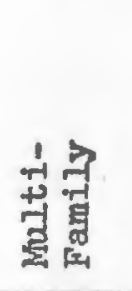 & 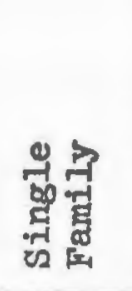 & 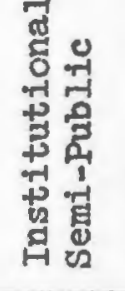 & 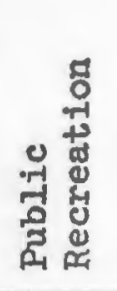 & 맹 & 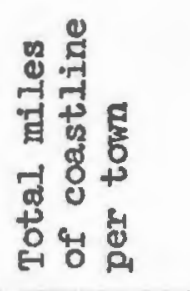 & \\
\hline *Cranston & 0 & 15.5 & 14.1 & 15.2 & 47.3 & 3.2 & 4.1 & 0 & $3.5 \mathrm{mi}$. & \\
\hline **Warwick & 1.1 & 5.6 & 0 & .2 & 49.1 & 3.1 & 8.4 & 31.1 & $38 \mathrm{mi}$. & \\
\hline $\begin{array}{l}\text { *East } \\
\text { Greenwich }\end{array}$ & 0 & 67.3 & 0 & 9.5 & 0 & 2.8 & 2.8 & 17.5 & $2 \mathrm{~m}$ & \\
\hline $\begin{array}{l}\text { *North } \\
\text { Kingstown }\end{array}$ & .1 & 1.1 & 14.1 & 6.8 & 32.7 & .1 & 2.7 & 40.8 & 29 mi. & \\
\hline & .30 & 4.13 & 5.43 & 2.38 & 29.24 & 1.40 & 3.48 & 24.10 & 74.46 & $\begin{array}{l}\text { Total miles of use } \\
\text { classiflcation }\end{array}$ \\
\hline & .3 & 5.6 & 7.4 & 3.2 & 41.3 & 1.6 & 4.6 & 34.4 & & $\begin{array}{l}\text { \% of total coastal } \\
\text { land use }\end{array}$ \\
\hline
\end{tabular}

Percentage of total coastal land use for each tow *Source - Fiela survey 1969

**Source - Warwick City Plan Dept. 1967 
APPLICATION OF THE ANALYTICAL FRAMEWORK 
This chapter will examine each conmunity in the study area in order that the specific nature and impact of decision-making factors can be explored. Ar attempt will be made to show how these factors express themselves to decision-makers. Because the econonic-ecologic dichotory and jurisdictions and controls factors play a passive role in the decision-fields of these communities, reference will be made to these factors within the context of discussions of the active factors of planning, politics and the marketplace.

I. Cranston, Rhode Island

The Evolution of Government and the Distribution of Legal

Authority: A Synopsis

On November 6,1962 , the City of Cranstion akopted the home rule provision of the 1951 Home Rule Amenament to the State Constitution.

Freed from the burzen of preparing Special Acts for submittal to the legislation for changes in daily operation, Cranston could adopt its own charter, enact and amend local laws relating to the municipality. The result was the creation of a strong nayor form of government within a mayor-council format. The mayor appoints and removes all city department heads with the exception of the City Clerk and Judge of Probate.

The current Democratic Mayor is the first and only mayor so serve under this charter and has held office for as long as any of the twelve mayors that preceded him dating back to $1.910 .{ }^{1}$

${ }^{1}$ City clerks office, City Government in Cranston: 1969-1970, 1969, pp. 8-10. 
91

The Council is composed of one elected member from each ward with three members elected at large. It has investigatory powers over all departments, fixes salaries, makes appropriations, levies taxes, grants licenses, and gnpoints members from its om ranks to boards and commissions. The city is divided into six wards. Each party has a nine-nember ward comittee. The coastal area of the city is encompassed by the first ward.

The broak grants of power resiaing in the Mayor's office are reflected in the orgenizational structure of Cranston's government. This is depicted in Chart D. There appears to be an equitable, logical and efficient allocation of authority anong the three branches of the municipa] covernment-..the administrotive and onerating responsibility restjng under the jurisdiction of the Mayor; legislative and fiscal control as a prerogative of the council; and the related but independent function of publj.c education in the school Department. It is clear, however, that the layor's office with its appointing powers and ability to interlock administration officials with apgointed officials, especially on the Planning Commission, can foster cxcellent cooraination of ideas and proposals among departments and commissions. Identification of Key Coasta]. Decision-Makers:

The Planning Jepartment, the Public Works Department, the Finance Department and the Redevelopment Authority serve to give the Mayor's office a great deal of leverage in directing comunity growth and public expenditures. These functions under the meyor have an importart role in detemining the definition and distwibution of projects carried forward in the operating and capital budgets. Because of 
GOVERNMENTAL ORGANIZATION - Cranston

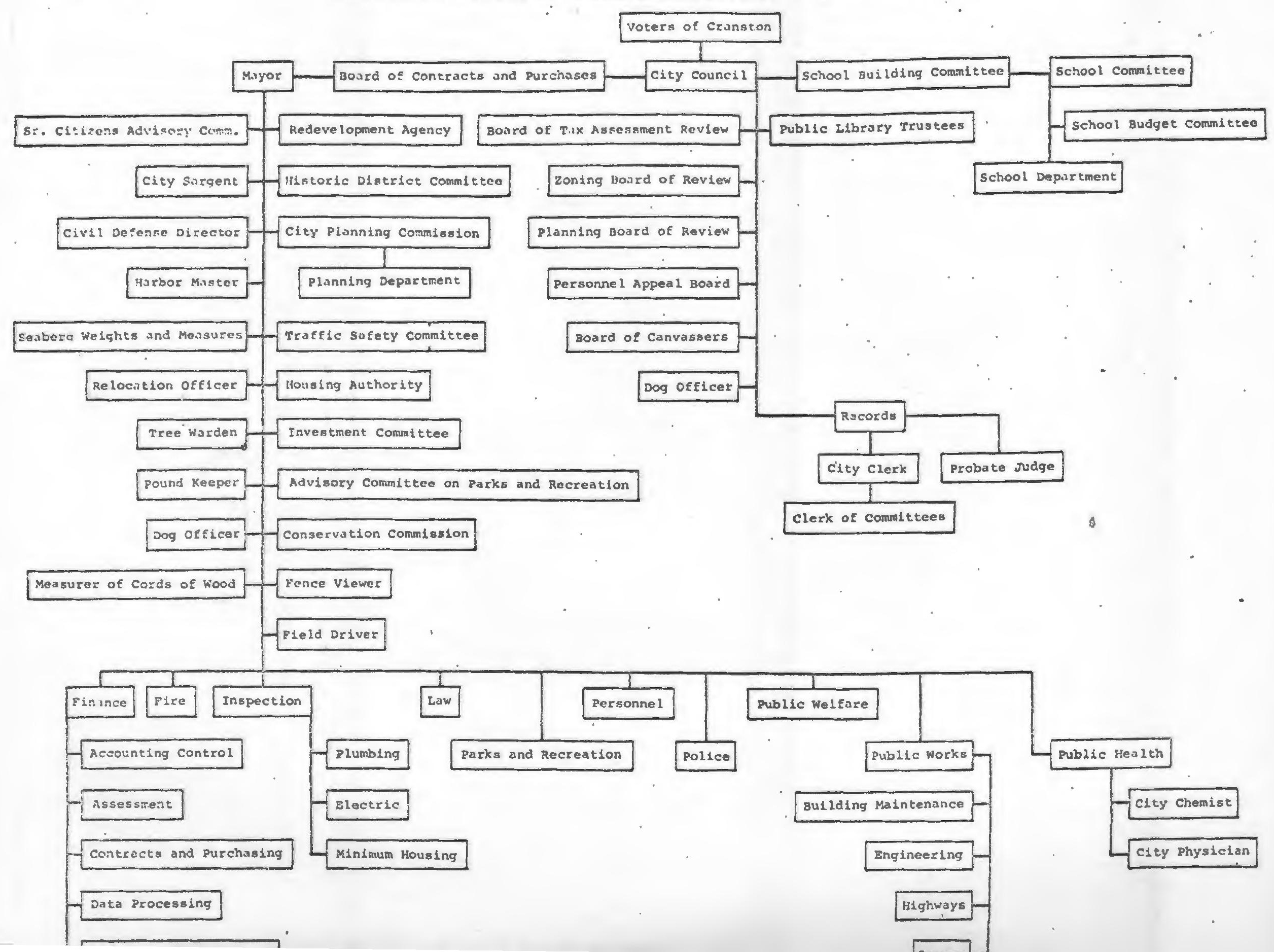


this administrative control and legal prerogative, a significant amount of authority is centralized in the Mayor's office.

With all of these key adninistrative and planning officials with. the exception of the Redevelopment Authority required by charter to be on the Planning Commission, this arm of the Mayor's office plays the primary role legally and in actuality in the formulation of development policy. Those elected and appointed officials interviewed in Cranston felt that the combination of the Mayor's office and the Planning Coramission outweighed in importance all others including the City Council in the formulation of overall development policy for the City and for coastal areas (Appendix A. Q. 1). The Planning Factor in the Decision-Field: The Comprehensive Plan: The Official Policy Document for the Management of Cranston's Coastal Environment -

The only policy document.concerning the coastal environment is the Camprehensive Plan prepared for the Cranston Planning Commission by Blair Associates of Providence in May, 1961. The plan deals specifically with the Edgewood Section (the coastal area) by reference to the general development goal of conserving residential areas and redeveloping Pawtuxet Village. (See Chapter III, Map II). No other coastal goal or development alternatives are discussed in the Report. The Comprehensive Plan is the only policy document capable of dealing with Cranston's coastal environment, yet it makes no direct reference to Cranston's relationship to Narragansett Bay. In drawing any conclusions about the adequacy of this document as a useful tool in shaping public coastline environmental policy, five standards of 
analysis will be applied. These are:

(1) clarity,

(2) internal consistency

(3) scope in termas of time span

(4) comprehensiveness in terms of variety of coastal activities

(5) operationability in the sense of being concrete enough for action.

Clarity - clarity in dealing with coastal issues must be present in terms of direct reference to Cranston's relationship to the Bay. The forword to the Comprehensive Plan outlines the purposes and the level of specificity the plan seeks to achieve.

(The Plan) presents a framework in policies and plans, supported with detailed information, to gujde the city in developing its resources effectively. The Comprehensive Plan. . (presents a) systematic and harmonious development for the city. It has been made with due consideration, among other things, to existing and projected factors such as population, land-use, and municipal economies, and is designed to lay the basis in city policy for the use of Cranston's resources for the general welfare of all its citizens. (The Plan is) designed to serve as a general guide. . (it) comprise(s) a concise statement of municipal policy toward development, spelled out in sufficient detail to guide city agencies that regulate land development, and to serve private investors seeking to determine when to develop land in the city. ${ }^{2}$

With the exception of reference to marina and beach facilities

on pages 1-60, and apart from recommendations dealing with the redevelopment of the Pawtuxet Business Center, no reference is made to Narragansett Bay or Cranston's coastal areas.

A Plan for Recreation and Open Space (1960), also prepared by

${ }^{2}$ Comprehensive Plan, the City of Cranston, 1961. 
Blair Associates, makes no mention of the state-owned stillhouse Core reserve as well as no mention of any potential for the coastline as an open space resource or possible location for open space acquisition. The 1961 Capital Improvements budget recommended by Blair Associates Included $\$ 62,000$ as the City's share in dredging Pawtuxet Cove, but no reference was made in any plan to improving land areas or stimulating redevelopment of anything but the comercial area. ${ }^{3}$ This area is the center of what was the previously distinguishable village of Edgewood. It now provides limited neighborhood shopping facilities. Based on these findings it can be said that Cranston's Comprehensive Plan lacks clarity in regard to coastal environmental issues and policies for it makes no distinction between coastal land and any other land areas of the city. Internal Consistency - In lieu of the lack of clarity in dealing with coastal environmental issues it is advisable to ascertain why Cranston would consider investing $\$ 62,000$ for dredging Pawtuxet Cove without direct reference being made to the effects this development might have on the Pawtuxet Cove Commercial Center. The Plan recommends the Pawtuxet Commercial district to be established as one of four major community business centers in Cranston. This would be accomplished through the use of renewal activities. The plan offers no guidelines as to the type of facilities, be it shopping centers, office buildings, roadside commercial or wholesale that should be encouraged, nor does the plan

3 Capital Budget for the Clty of Cranston, prepared by Blair Associates, Providence, R.I., 1962, 2. 18. 
attempt to direct any new housing into this area which had been established as the nucleus of Cranston's development evolution. The Plan Itself concentrates on development of new housing units in Western Cranston, but it does not deal with the adequacy or demand for rental units. In no case does it recommend sites for public or private housing projects.

The plan appears remedial in nature. It seeks to stimulate redevelopment but not to deliniate types of development. No apparent consideration was given to questions of development quality, potential users or beneficiaries from the pawtuxet Cove improvement. No consideration appears to have been given to Cranston's relation to Warwick either as a related land jurisdiction to the comnercial area or the cove, or to Warwick as a governmental institution with which joint planning for the cove and commercial areas might logically occur.

It can be concluded that Cranston's attempt to stimulate redevelopment of Pawtuxet Cove was made without regard for or realization of its total coastal environment or relation to regional coastal considerations. Indeed, with the exceptions of the thoroughfare plan, the Comprehensive Plan is completely inward looking and does not draw reference to Cranston's relationship to larger cultural or natural features such as the Providence SMSA, the Pawtuxet River Basin or the Bay. Scope - Cranston's plan makes reference to a cutoff date of 1975 for the Plan. Despite the statement in the foreword of the Plan quoted on page 96, no priorities or dates were documented for completing proposed land-use changes or redevelopment. Indeed other than renewal activities no guidelines or actions were mentioned for directing this intensi- 
fication of land-usage. The stating of 1975 as a target date for conpletion of the plan appears arbitrary without detailed proposals to justify this dete.

Comprerengivenoss - A low rating must be given to Cranston's plan in terns of its comrehensiveness in dealing with coastal environrental issues. No reforence is made to water pollution (although all those interviewer felt this to receive tho highest priority amorg local enviromental issues), open space preservation or creation, public access develognent or any of a host of coastal envircmental concerns (Appendix A, Q. 6). Stillhouse Cove, a state facility, vas neither mentioned as a potential conmunity rescurce or area for recreational develogment. Recreational development in the Cranston Plan appears to be defined in terms of sctive particination needing major faciljties and space with little regard for individual passive enjoyment, which might serve a larger segment of the population. Operationability - Page I-75 of the Cranstor Plan states the following:

The Corprehensive Plan may should bo distinguished from other, more specific plans, such as engineering drevings, architectural plans, urban rerewal pl.ans, or the zonine map. It is, rather designed to serve as a general basis for such specific plans, each of wich will. requjre further interpretation and study to be formulated. ${ }^{4}$

Using this statenent as a guide, it is clear that the authors of this report vicw the plan as being a passive document which is wel]. removed from the action phases of comunily development. Mile it states hor 
implemeriation might occur, i.e., renewal and public expenditures, it makes nej.ther strong specific statenent to zoning changes nor mentions zoning as an inplenentetion measure for the plan. The very broad concoption of the function of the plan offers little useful guidance in the creation of a coastal envixonriental policy. Summary: The above analysis indicates that Cranston's Comprehensive Plan has several major shortcomings as the only technical and policy docurient dealing with the community's coastal areas. The Plan offers little guidunce for either short or long range investment decisions for private enterprise and lacks the specificity required to be a meaningful guide to dáily public decision-malring. City Plgnning Orpanization and Position:

Though the fomal organizational chort does not tej.1. all, it does tend to position people and groups in a way which implies roles and lines of communication. In cranston this is an important consineration in deternining the position of the planner, and hence planning in this case, in the governmental hierarchy. The close lines of formal commication are shown in the requircment that the Finance Director, Public Works Director, and a member of Council shall be a member of the Planning Commission. The physical proxinity of the Plenning Office next to the Mayor's suite in City Hall (the Redevelopment Agency is isolated five miles away) serves to demonstrate the close physical, legal and psychological linkage among the planning and inplementation agencies and the Mayor's Office. In Cranston the Planring function holds the ralker Position described in Charter II. In on interview, the Planning Director indjcated that he felt 
the Planning Comnission should act as an advisory body to the Mayor and Council. He personally viewed his Department as being an adjunct to the Mayor's Office where he served as a member of his "cabinet" on planning and other matters. The Planning Department with an annual budget of $\$ 58,000$ consists of the Director and six sub-professionals. Major planning studies such as the corprehensive plan and capital improvements program have been completed by consultant services. The most significant weakness in the planning performance eppraised by che Director and two other decision-riakers was lach of internal technical ability (fppendix B, Q. 39).

The Planning office, which should be the locus of coastal policy formulation, has only one planner, the Director, who may qualify as a professiond by the standards set forth by the Amaxican Institute of Planners. $50 \%$ oi his time is spent handling routine planning tasks (Appendix B, Q. 31). Environmental approaches such as definition of areas of environimental quality or liability are not actually undertaken by his ofrice. The Director who handles a.l aministrative vork for his office jsoletes planning employees from whatever planning conflicts might orise (Appenaix $B, Q .32$ ) and seeks new eimployrees through civil service advertisements and examinations (Appendix B, Q. 34). All promotions come from within rather than outside his department (Appendix B, Q. 34). If he were to hire new employees which he has not in the last three years, he would seek "average or better ability in reading, writing and arithmetic", despite in his opinion that his department lacks intermal technical ability (Appendix B, Q. 35, 36, 39). Internal trainino is gjven by the Director plus extension school 
courses at the University of Fhode Island. In recommending these courses the Director stresses the achievement of basic verbal aud mathenatical skills (Appendix $B, 6.37,38$ ).

The close legal and aoministrative ties between the Mayor's office, which possesses a high degree of authority, and planning function indicates that the planning department in Cranston is vell positioned to assume a developmental approach to its activities (see Chapter II, p.32). The professional weakness of the planing staff and shoriconings of the Comprehensive Plan pose limitations, however, on assuming this generalized approach to the pianring task.

Planing Strategy:

To determine how the planning function, in this case the Direstor, attermpts to influence decision-makers operating in the decision-field, the approach applied by the department in carrying out its duties must be examined. Because the planning factor usually corpetes ritin other factors in the decision-field conflict situations often arise. In such instances the planning function usually pursues a policy leading towara cormunity change, while often the political factor seeks stability.

In the view of the Planning Director and other dccision-makers observing the planning process in Cranston, the tension between the planning process pushing for change ond the counter-st.abilizing force of political accountability is not in existence. The Director, when queried on how the Departmont reacted to rublic criticism (Appendix $B, 0.40)$ in conflict situetions felt that there was no significant public criticisin to his planning proposals. He believed his actions 
101

were supported by the electorate in returning the Mayor to office in 1966. He expressed the need for planning to respond to rarket and political factors. These factors were beyoud the capacity of planners to greatly change, he believed.

over the course of two interviews, it hecare apparent that the Director viewed planning as a mechanism of coordination, and that his own role was one of acting to remove the rough edges of the foress of economic change wilch he felt could not be significan'ty alterea in the case of coastline development. He felt that while coastal landuse evolution would accelerate, there was no specific deadline or schedule to be irmosed on such a transformation.

The Director viewed the Conprehensive Plan as a broad and agreed upon docunient for stimulating economic growth (Appendix A, Q. II). This position was secunded by all interviewed in Crarston althoush they questioned the usefulness of the plan in light of its vagueness in dealing with specific development proposals for coasial as vell. as other areas of the City. When queried on this point, the Director said that the Comprehensive Plan should set broad guidelines to be acted upon by more action oriented agencies such as the Redevelopmert Authority. Such an agency, on a project basis, would make detailed proposals dealjng with density changes and now land-use configurations. The Redevelopinent Director's views reflected these attitudes as well but felt, as did others intervieved, that the vlan only reilccted existing land-use and offered no clear criteria to be acted upon by his agency in dealing with change in the coastal. axeas (Appendix $B$, Q. 12). 
These opinions cast the Plaming Director, and he felt his viers generally represented the Plaming Commission, as favoring the ad hoc opportunist strategy defined in Chapter II, page 29. Though this strategy is adoptive in approach and implies a veakness in the planning function as a factor in the decision-field it is not, in itself, sufficient evidence to judge the pJanning function's capabilities as the primary agency for coastal policy creation, implementation and adjustment. To make this assessment five standards, established by Meyerson, for making planning more effective will be applied. 5

(1) Central intelligence function - to facilitate market operations through the issuance of market analysis and similar tecinical reports.

(2) Pulse-taking function - to alert the community through quarterly or periodic reports to danger sjons in environmental deterioration, econonic change's ara population shifts; also to be sensitive io social pressures and hostility in the community.

(3) Policy clarification function - to help freme ard regularly revise developrent objectives.

(4) Detailed Development Plan function - to phase specific private and public programs as part of a comprehensive course of action covering not more than five years.

(5) Feedback and Review function - to analyze through careful research prograns and projects activities as a guide to further action.

(1) The Central Intelligence Function - The Planning Department to date has issued no known technical reports. Consulting pjanners and engineering firms have been responsible for the preparation of all major plans. The Director expressed an apparent intuitive feel-

\footnotetext{
5 Martin Meyerson, "Five Functions for Pianning", J.A.I.P.,
} Spring, 1956. 
ing for changes in the econory of his city, but showed very little awarencss of regional or cconomic trends which might affect Cranston. No official market reports have been issued by the Planning Department even though groups such as real estate developers, business and residentisul cwners, and conservation eroups regulariy demand services of the planning function and receive advice (Appendix B, Q. 17, 18). Such advice usually consists of suggested locations for development permitted under tive zoning ordinance. In acidition the office provides maps and act,s as a clearing house for citizen requests regarding tax assessment practices. The Planning Department also acts as the main link between city government and federal fundine sources for such progratis ass OrO and education. In ihese insiances the Department serves as a technical resource in appl.icaition preparation but apparently does not initiate action. The Department steks to promote industrial and commercial expansion by supplying site and cost information to inquiring concerns but has no prograr for attracting these concerns to Cranston. None of these sites is on the coastline, even thougl the Director acknowledges the potential for comercial growth in this area.

(2) Pulse-taking Function - Despite the acdition of the runctions of environmental quality, open space, and recreational parks äuring the last two years (Appendix B, Q. 11.), the planning function has no systematic rechanism for ascertaining qualitative changes in the coastal areas. Even though thesc new function have been assuned in name, there is no evidence that they are bejng applied in shaping the planning viewpoint on coastal enviromental management policy. Con- 
sistant with the Planning Department's lack of interest in sustaining the pulse-taking function in the area of coastal environmental quality was the Director's appraisal of the public concern about the coastal areas of Cranston. He felt Cranston's residents were more urban-service oriented and less concerned with coastal natural areas than perhaps the more rural oriented populations in towns to the south. All of those interviewed felt that the city's greatest resources were in western Cranston for every type of development.

(3) Policy Charification Function - In light of the lack of direction provided by the Comprehensive Plan in guiding coastal development, it could logically be expected that in the eight years since that plan was written development objectives for the city's coastal lands might be defined. This has not been done by the Planning Department.

Zoning for the 3.5 mile coastal area which in theory should reflect the Comprehensive Plan spans seven of the City's fifteen zoning categories permitting a total of thirty-nine uses and representing twenty-seven additional stated uses under which special permits can be received. These uses range in intensity from general industry $(M-2)$ to uses containing a high proportion of open space (s-1). The zoning conforms to the land-use pattern and in some cases (A-12) permits smaller lot sizes than existing land-use patterns. The zoning code was adopted by referendum after the plan had been approved by the Council. The satisfaction of the Planning Department with present zoning classifications for the coastal area accentuates the Department's weakness in the policy-clarification function. 
(4) Detailed Development Plan Function - There is no detailed development plan prepared or being prepared by the planning function for the coastline. Jhe Comprehensive Flan wijch the Director views as fixed and rell agread upon but which others feel is revised according to circunstances (Apporidix A, Q. 13) serves as the only guide. There appears to be no coordination in this planning function between the Redevelop!nent Agency and the Planning Devartment, even though the Director of Planning feels the Redevejopment Agency should make projects conform to the guidelines set forth by the Comprehensive Plan. One reason for this lack of coopcration appears to be a personal tension between the Planning and Redevelopinent Directors. This is the result of a major confrontation (see Chapter $V$ ).

(5) Feedback and Reviev Function - For cosstal areas ali feedback eppear's to be political in nature and bears no reflection on professional planning criteria for enviromental management. The Planning Director is a relative to both a former Governor of the state and a present City Councilman in Cranston. He is a long time resident of Cranston, residing there while erployed as a consulting engineer before assuning his present position in 1.560 besore the Comprehensive Pl.an was published.

Because the Planning Director appears to have a narrowly defined view of his job, he apparently seeks to solve irmediate problems without developing larger rarge objectives for either his Dcpartment or the City. Without stated goals or a program for achieving then, it becores nost difficult to meaningfully arpraise the effectiveness of ary coastal policy positions. Though the Diroctor was aware of the 
economic forces being focused on coastal land in Cranston, he did not consider real and proposed changes in coastal land-use particularly significant (Appendix B, Q. 24). One might conjecture that because the Director views market and political factors as undeniable determinants in the decision-field, the feedback and review function in his view means assessment of the positions of spokesmen for those factors. Those positions appear to serve more as a guide for his personal action than as a point of mediation between planning, political, and market factors in the decision-field.

Summary: The Potential Irpact of the Planning Factor

Although the real impact of the planning factor in the decisionfield will depend on the relative strength of competing factors, it is possible to assess the planning function in Cranston on its internal capabilities discussed above. The greatest strength of the planning factor lies in its close administrative and legal position near the executive authority of the Mayor's office. Despite this proximity, the adaptive approach and weak strategy for coastal policy formulation applied by the Planning Department offsets the advantage of the position of the planning function in municipal governmental organization. The Department itself suffers from weak professionalization, and poor technical data and documentation for creating and judging coastal policy alternatives, and weak capability and procedures for focusing the planning process on coastal environmental concerns. As a result the planning factor has no coastal policy or method of devising one for presentation to decision-makers who are also considering the positions adrocated by spokesmen for other factors in the decision-fiela. 
The Political Factor in the Decision Field

Five traditional interest groups seek to express in the decisionfield their viewpoint for the final coastal environmental policy adopted by a given municipality. Though their views often contraaict each other, their combined interaction with decision-makers constitutes an important factor to be explored in Cranston's decision-field.

The Conservation Commission in Cranston is directed by an energetic state employee who is chief of the Division of Conservation in the State Department of Natural Resources. The City's Commission is the only authorized group in the governmental structure whose sole responsibility is to advocate the conservation and ecologic point of view. He lives in the still rural atmosphere of the western part of Cranston, an area undergoing rapid development. The major focus of his activities during the last three years has been the reservation of greenways along water courses in that part of the city. He viewed the function of his Commission as providing more life amenities (Appendix B, Q. 22). He was aware of the mounting market pressure for change that was occurring in coastal areas (Appendix B, Q. 24) and felt that the only way they could be controlled to preserve or improve coastal environmental quality was to add a constitutional amendment guarenteeing the average citizen the right to a clean environment and to authorize greater public control over development (Appendix B, Q. 42). He viewed present development regulations useful but far too weak (Appendix B, Q. 38) .

The commission chairman rejected the Planning Department as the best agency to determine coastal land-use policy, because of "their 
proven inability to conclude what they start." He favored instead a Ray Authority which was geographically based and enpowered with authority to aajust taxes and impose fines to that activity pursuing or working against public development objectj.ves for the coast. He felt that state-wide taxation and zoning powers were a necessity (Appendix B, Q. 51, 52, 55). The City Council, he believed, say Cranstion's Comprehensive Plan as a mechanism for stimulating growih, but felt the Plan had no defined objective for the coastal area (Appendix A, Q. 1.5). Local residents were seen as the greatest determinants to the final public policy position taken for coastal areas. He fel.t satisfaction with present levels of performance was the greatest constraint to pursuing new ideas for coastal manafement (Appendix A, Q. 23). He expressed a need for more money to be spent on coastal prograns, a]though he could not specify which programs in particular (Appenoix $A, 0.25$ ).

When queried on what activities his Commission was currently undertaking in coastal areas of Cranston, he replied nore. He felt that the low water quality, both on the Bay frontage and in the Pawtuxet Fiver as well as the highly developed nature of the area precluded the type of major irmpovenents that he viened were reeded to up grade the area. He thought only a significant comnitment of the local government could make a. lasting impact on the area. He felt the principal environmental liabilities of the coastal. environnent vere: water polzution, deteriorating buildiñ̋s and public services, mixed land-usage and over developinent of shore frontage.

With only a fev hours weekiy to devote to the Commission's work, he believed he could make the greatist overg,l contribution to the 
city's conservation prograin by focusing on the yet undeveloped land in western Cranston. He felt the lack of interest expressed by the planning Department on environmental concerns as well as the sensitivity of the Mayor's office to the local landomers' views precluded the Commission making any meaningful impact on the envirunmental problems of the area. The Comission would, however, actively support any group interested in coastal environmental improvement. He thought such a group would have to be state or nationally based to exert much influence.

Taking into account these views, the impact of the Conservation Cormission on coastal policy formulation can be appraised as low.

Iandowners, especially residential landowmers, have a significant impact on ths position decision-makers take on sanctioning coastal land-use change. One group sensitive to landowners' views and sometimes acting as an articulator of these views in the comunity communication network is the local ward comittees. When strongly contested issues arise, however, landomers interact direct]y with the Mayor and Councilmen.

Many of the large residences of the 1890 vintage which characterize the coastal land, referred to as the Edgewood section, remain in excellent condition. Owners of these homes are in upper income brackets and represent the high income residential character which established the Edgewood section of the City as a prestige address similar to those found in the East Bay region in such towns as Newport and Litt.le Compton. These high-income individuals though fewer than in the past have frequently expressed thein opinjons on market or planned change in the area. They have hired lawyers to ropresent their view-point when zoning 
changes have been requested by developers and successfully stopped the Redevelopment Authority from developing plans for the Pawtuxet Cove commercial center (see Chapter $\cdot \dot{v}$ ). The Planning Director described these residents as very influential with the Mayor's office, although he would not speculate on the source of this influence.

on one recent occasion these residential owners successfully defeated a developer's bid to have part of the area rezoned to permit apartment units, even though the developer was able to acquire six adjacent parcels from other landowners. In another instance local residents successfully stopped an attempt by the Redevelopment Authority and local businessmen who had recently become aware of their drop in sales volume, to revive a once defeated development plan for the area.

All those elected and full-time city employees interviewed expressed the view that though few in number these landowners possessed. the resources and political impact to thoroughly arouse the community about proposed changes in the area. Politically sensitive Councilmen felt that once such a controversy was initiated it became particularly difficult to appease the many divergent positions that became strongly expressed. From their point of view it was far better to keep such controversies from arising than suffer the turmoil that resulted from public sanctions for change in the coastal areas.

It appears on the record of decisions made by the Council reflecting the position toward change held by local landowners that this group has a great impact on the position finally adopted by Council. Developers were seen to present persuasive views to decisionmakers (Appendix A, Q. 4). This assessment was made by the Planning 


\section{1}

and Redevelopment Directors in appraising the political inpact of developers. Although their desire to change the coastal land-uses has been denied by Council in recent cases it is clear that the supercession of land-uses recognized by all those interviewed is occurring gradually in Cranston's coastal areas. This is increasing the frequency of the developers' appeals for greater land-use capacity to be sanctioned by local zoning laws.

Developers to date are favoring only certain types of land-uses. High density residential uses such as apartments are most vocally advocated. Commercial facilities such as motels are also seen as economically justifiable types of development. There appears to be little interest expressed by commercial developers, however, in up-grading the Pawtuxet Cove commercial area. Because developers act as spokesmen for market influences their impact on decision-makers is increased by the force of the market place in affecting change. This market factor interacting in conjunction with developers is discussed as a decisionmaking factor in Cranston on page 116.

Based on the increasing number of petitions by developers for changes in the coastal area, the impact of developers and the market factor they represent appear to be rapidly increasing.

Influential Citizens and Institutions in the description of the political factor prove difficult to define empirically. Apart from those individual landowners who were described above only the institutionalized views of the membership of the two yacht clubs located on the shoreline can be said to be expressed under this category. Historically these clubs, especially the Edgewood Yacht Club, served as a 
social gathering place for Cranston's most influential and wealthy citizens. That was in an era when the quality residential character of the area was intact. Because these institutions acted representing the consolidated views of many powerful citizens who desired to maintain the prestigious character of the coastal area. Those board members of these institutions once had a substantial impact on coastal public policy. Today, however, these social clubs no longer exercise a discernable impact on public policy. The low water quality and deteriorating condition of the physical structures of these yacht clubs demonstrate the degree of change that these institutionalized uses have experienced in recent years. These spokesmen within the large political factor no longer have a visable effect in shaping coastal policy.

The elected, appointed and adminis trative staff can be considered a significant potential force shaping the final public policy position. Leadership in government embodied in these officials has not only the potential for arousing community support for coastal programs and policies, but also the legal authority to recommend and carry through the budgeting process a consistant approach to coastal environmental improvement, if so inclined.

Those elected and administrative officials interviewed, such as the Conservation Commission chairman, all possessed the academic qualifications to support such a leadership role. All have advanced degrees in such fields as law and public administration (Appendix B, Q. 2). By professional background each had sufficient experience to have a thorough grasp of coastal ecologic and development problems.

Elected officials showed an inclination to actively pursue the 
implementation of desired objectives despite obstacles, and to increase their own influence where possible (Appendix B, 6. 46, 47). Each fel.t on cozstal matter's the advice of planners and ecologists would be nost Liseful (Appendix B, Q. 4,8). All favored betier coordination of programs in government for the ccastal enviroment (Appendix B, 6. 51). Zoning and performance standards applied with the use of easements and cluster zoning were seen to be the best way to control coastal cevelopment (Appenaix B, Q. 52, 54). All agreeù more money shoulà be spent on coastal problens despite increased taxes on all levels of government (Appendix A, Q. 25, 27).

Despite these views and qualifications, only the Redevelopment Director atterpted to show any leadership in attemping to improve cosstal enviromental quality (see chapter V). All felt that protection of existing uses was the development objective that appeared to be the actual policy in effect as a result of council actions (Appenaix $A$, Q. 25) and that propericy owners views vere the most carefully corsidered force of those present in the decision-field (Appendjx A, Q. I6).

It can be concluded that despite personal qualirications and the positioning in or near real positions of power; and regardless of views expressed as to how alternative coastal measure and land configurations might be employed, no elected or administrative person is now assuning a lcadership position sponsoring coastal environmental procedures. It is evident that these officials are not playing an active role in directing coastal environmental change in the communicy. Sumary: The Polentiel Irnect of the Politicel Factor

Despite the disparate views expressed by spokesten within the 
political factor, it is clear that local landowners are able to present the most forceful arguments for their views. The action of the city council in zoning questions has reflected their sentiments. The landowners represent the dominant land-use of the coastal area. Because this residential use appears to be in a period of supercession, the views expressed by developers are being presented more frequently. It appears their voices for change will scon equal in impact those of the landowners. With landowners willing to sell their properties to developers, as has been the case in several instances, the developers will undoubtedly receive the sanctions they seek from public authority as the strength of the landowners position is diminished. The Market Factor in the Decision-Field

One of the first indications that market forces are actively shaping land-use patterns are requests for zoning changes. One way to project where petitions for land-use intensification might logically occur is to analyze the amount of vacant land available for development. The Planning Director in making such an analysis estimated gains in population of only 9\% in the period from 1965-1985 for Ward 1 compared with $28 \%$ for the entire City for the same period. Despite this low estimate of projected population change in the entire Ward, requests for zoning changes and variences have numbered 15 for the immediate area of the coastline during the past year. These requests were for changes in yard requirements and for increasing density of single family units to multiple family units. 6

Division of Inspection, City of Cranston, Jan. 1970. 


\section{5}

Developers have also petitioned for zoning changes to nermit apartmeni consiruction on land abutting the ocean. The rajor commercial use on the coastline has been acquired by the Hilton Hotel Corporation and is seeking room to expand this motel's meeting and convention facilities.

Tohn Picerne, a principal in Kelly \& Picerne Renltors and Developers of Cranston, one of Rhode Island's largest real estate firms, stated during an interview that the national trend in apartment living was just beginning to reach Rhode Island and that coastal areas offering an expanse of visual space "enormously enhanced" the value of such a development from a realtor's point of view. He felt this was the logical land-use for Cranston's coast, but felt with good transportation access apartment complexes of 100 units or more could be profitably built on any coastal point in the study area. He noted that tenanis for such units were usually young married couples without children, providing two incomes. Forty percent of these farnily incomes excecied $\$ 10,000$. He felt on account of the quality of amenities these tenents wore seckjng, e.g., swimining pools, temis courts, etc., complexes of less than 100 or more units vere not economically justifiable.

The greatest problem facing the developer in Cranston lies first in acquiring two or more adjacent sites with land-use capacj.ty capable of returning a profit and secord receiving governmental sanctions for his proposals. Developers have been able to rake the acquisitions necessary for such higher use proposals. Because of the many zoning classifications auplied to this shori cosstal area, the aeveloper has many strategy choices available in whether to seek outright changes 
or exceptions or variances.

On account of the small anchorage size of Partuxet Cove, redevelopment of this areo, for marina use as suggrested by the Compiehensive plan cannet easily occur by the private sector because of the mixed land-uses and lack of both weter and shore areas for anciliary uses. In this area small lot sizes and variety in zoning classifications makes this transition difficult to contemplate for developsrs because of high development costs and difficulty of porsuasively arguing for zoning sanctions.

Apartnents, however, are in national and local demand. They can be built on one or more of the single-family residence sites which away from the Cove area average nearly $1 / 2$ acre each. Such units are considerea by tenants as highly desjrable because of their visual

rather than actual access to the coastline. It was this type of landuse which was seen by all interviered as being the most likely manifestation of the market influence. Because of the age and marital. characteristics of the tenants, dcvelcpers can persuasively argue that they are provjding housing for Cranston's midale and low incoms work force without adding to the City's educational expenses. It has been argued that such new uses actually add to the City's housing stock by replacing inefticient oläer units, such as victorian houses, with new units which serve a Ereater segment of the population.

The change of older uritis classified as consurption uses to production uses, such as apartments and comercial facilities, results in not crily increased real proporty valuation, but also an assurance of more expendibse incorse beirg pumped into the local economy. These 
occurakies can be seen as desirable facets by decision-makers.

Negative facets can be accounted for in the need for public expenditures for increased services such as roads and sewage facilities for such land-use changes. Unlike schools, however, the irmact on these services is gradual unless the scale of the developer's proposal necessitates major changes. Summery of the Potential Impact of the Market Factor

Coastal land is in a period of transition fram single frmily consumption uses to nulti family production uses. Developers are advocaiIng higher and better uses while a decreasing number of land owners seek to maintain the status quo. Demand for increased land-use capacjty is effecting land prices. Turnover of costal parcels of land is at a hj.gher rate than more immediately adjacent inland parcels. Assessing evaluation based on re-evaluation base year rather than on current sales nakes comparative lanả value changes difficult to deternine. The increasing demand, however, indicates land prices sre rising. As this demand continues more petitions will come hefore Council. It appears that the market factor will have an increasing impact on coastal environmental issues as they are acted upon by decision-makers in the decision-field. Sumnary of the Potential Impact of Passive Factors: Economic-Ecologic Dichotomy and Jurisdictions and Controls

There is no evidence that the ecologic viewpoint is represented. in the decision field in Cranston. Economic and political considerations dominate all conservation and ecologic facets of coastal areas. These latter facets of Crarston's coastline have no spokermon in the 
118

decision-field.

Jurisdictions are recognized most universally by officials in protecting individual property: Municipal controls such as zoning appear to be adjusted to reflect the desires of local citizens whose political impact is considered great. Controls do not appear to inhibit decision-makers because they seek to maintain existing landuse patterns which have local political impacts. 


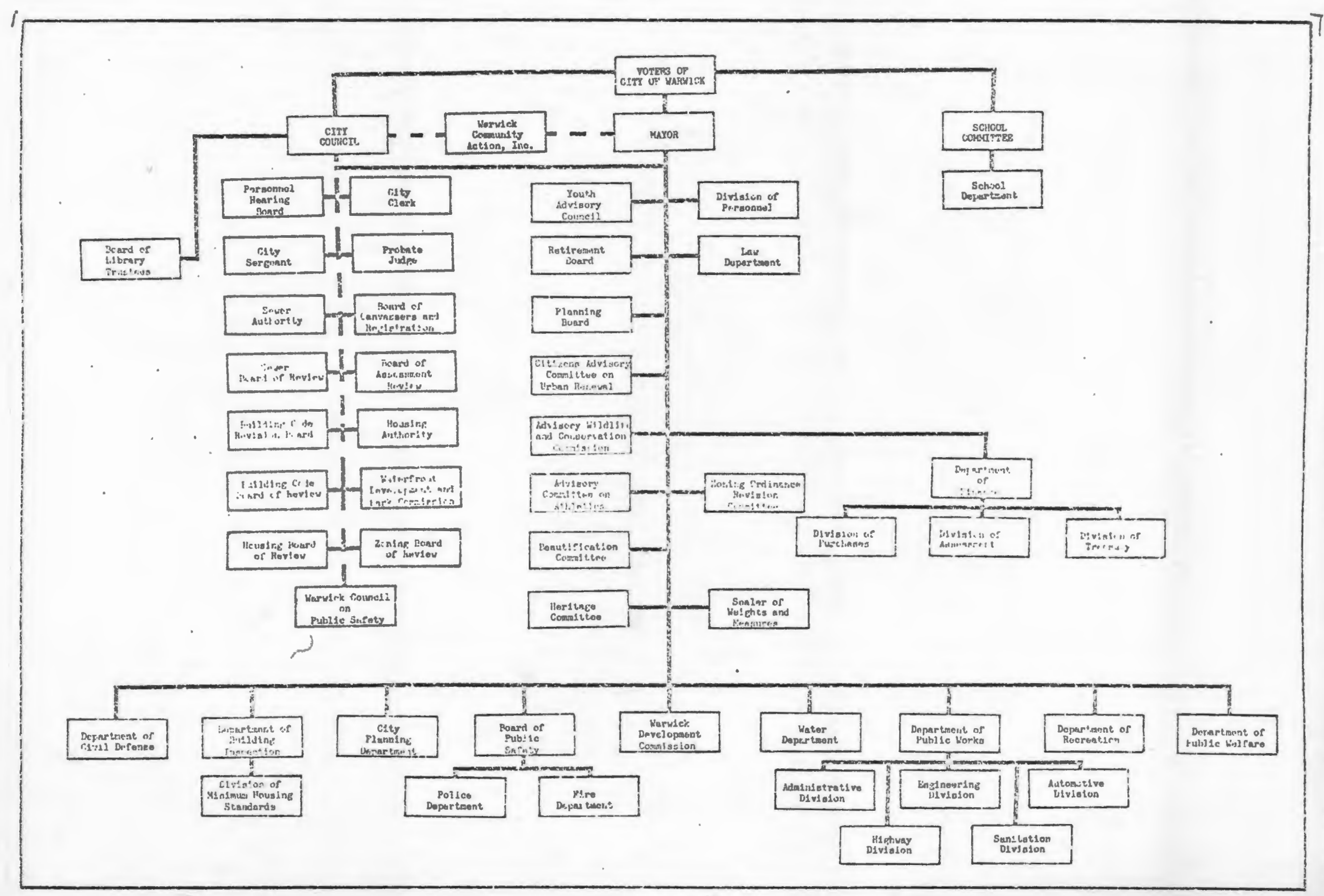




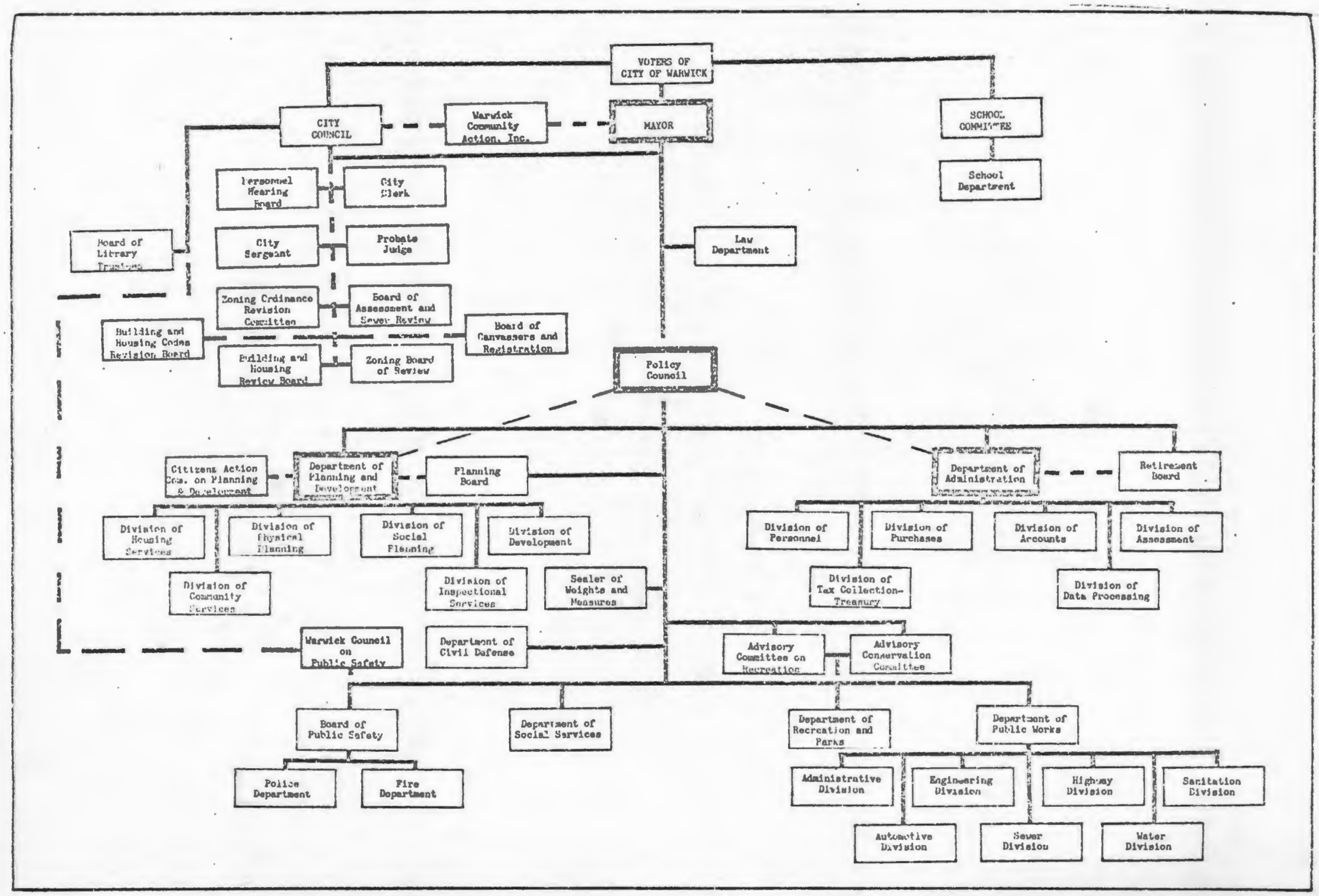


II. Warwick, Rhode Island

The Evolution of Government and the Distribution of Legal

Authority: A Symopsis 7

City goverment in Warwick has evolved through three definable periods. (1) From Settlement - 1933 - During this formative perion of development town government functions were distributed among a large number of boardis and commissions. Decision-making was accontrlished first through town meetings and later by a town council. (2) From 1933 - 1960 - The City of Warwick was incorporated in 1933. The Charter provided for a strong council-weak mayor form of nunicipal government. The Mayor served as the ceremonial and political representative of the City, while the Council comittees supervised administrative agencies. Gradually adninistrative responsibilities vere added to the Mayor's duties during the $1950^{\prime} \mathrm{s}$. Attempts at Charter reform failed, however, and the strong mayor movement weakened in 1958 when a semi-autonomous Waterfront Development and Park Commission was established. This Conroission answers to the Counci]. (3) From 1.951. Present - The moving forces behind Charter reform activities during the 1950's finelly succeeded in having a new Charter enacted in 1961. The effect of this change was to foster greater professionalism in the City and place executive and administrative authority in the Mayor. In 1959 yet enother Cinarter study was underiaken as part of the Community Renewal Program sponsored by the Mayor's office. City government was

7 The basis for this historical section was an umpublishel paper: J. Anderson, Charter Reforin for lunicinel Covernment in Warbick, 1969, p. 2 . 
reanalyzed and a report issued. ${ }^{8}$ Present muninipal organization is shown or: Chart $\mathrm{F}$. "Ihe Slavet Report" recominended that the City government be reorganized around a policy council which would be directly responsible to the Mayor. This proposed organjzation is shown on Chart F. It was felt this arranjment would permit the greatest impact of governmental development policies on municipal problems. It was also thought that such an arministrative organization would overcome the basic problems of the present governmental organization. These problems are: proliferation of narrowly-derined, single function agencies; inadequate full-time staff; part-time administrative boards and comissions responsible for wajor operating responsibilities; and semiautonomous agencies undermining the liayor's responsibilities as chief executive and administrative officer. 9

The Chartex reform issue vas defeated in Council by three votes. The major reason for these negative votes expressed by Councilmen interviewed was that the proposal placed too much pover in the proprosed Department of Planning and Development. The Planning Director fel.t, however, the negative votes wore resulted from fear of losing Council patronage privileges.

The grants of power to the Mayor's office recormended in the Slavet Report are based on the conceri of increased eficiciency in government through professionalization and deligation of authority to

${ }^{8}$ J. S. Slavet and M.K. Levin, Reoort on Administrative Organization: An Investment in Nunicinal Excellonce (Warrick, R.I.: Comunity Renewal profrem, Feb. Ic.68).

9 Ibia., p. 10. 
these professionals. The attempt here was to create a clear legal and real distinction between the decision-makers on policy on the Council level and the policy initiators and implementors residing under the Mayor's office. The fact that the proposal was narrorily defeated indicates the community's willingness to seriously consider such major structural changes in Warwick's government. Identification of Key Coastal Decision-Makers:

Inherent to the concept of govermental reorganization supported by the likyor is a necessary close rorking relationship among staff professionals and the Mayor's office. As in Cranston, the Planning Department acts as the key development policy locus in aiding the Mayor's office in creating programs for community development. These alternatives are made on professional planning criteria but without the Planning Board acting as a politicnl lightning rod in this process. Thus the Mayor and his staff agencjes such as the Planning Department, are the primary initiators of general development poljcy. Those adninistrative and planning interviewees assuciated with the Mayor's office and planning function thought the Mayor and his staff had the greatest impact on coastal development decisions, while the Council and appointed personnel indicated that the Council and Waterfront Development Commission were the prime coastal policymaking body. (Appendix A, Q. I). These divergent views were made comptible in subsequent discussions. Because the Mayor and Planning Department defined the issues and alternatives ior decisions to be made, they felt they had the greatest effect on determining coastal policy. Because the Council made the actual choices among policies presented and left the prouraning of the 
specific coastal policy to the Waterfront Development Comission, they believed they had the greatest impact on coastal policy formulation. On the basis of the Chartex reform proposal it is clear an attermt was made to increase the authority of the Mayor's policy formulation function to include detailed programing of implenentation phases. The present capacity of the Planning Department as the initial formulator of coastal policy makes it the primary decision agent in the municipal. government's approach to coastal environmental management. The Planning Factor in the Decision-Field:

The Comprehensive Plan: The Official Policy Docunent for Management of Cranston's Coastel Environment -

The primary policy document for articulating the City's position toward the coastal environment is entitled: Master Plan - Recreation, Open Space, and Waterfront (IP - RON) prepared by the Planning Department and adopted by Council. in May 1964. The plan documents the needs and programs for recreation, open space and waterfront developinent in the City. The objective of the Plan relating to the coastal environment is:

the maintenance of wildife conscrvation areas and the development of opportunities and suitable locations for further private commercial development along the City's 39 mile shoreline. 10

This objective was thought to meet some of the City's recreational needs as well as expanding the econcmic base of the community (Appendix B, Q. 22). The plan includes for the coastline a development approzch

${ }^{10}$ Master Plcn - Recreation, Open Space, Wateríront (Varwick, R.I.: City Plan Dept., 1964), p.A-I. 
using the following methods:

(1) land acquisition for future needs

(2) strategic capital investment

(3) development of land for immediate use

(4) retention of open spaces.

The overall objective of the plan is incorporated by the development strategy defined in the $1968 \mathrm{CRP}$, to be discussed in the following sections. Seven explicit recreational open space and waterfront goals are stated which serve as the basis for the aforementioned implementation methods. Though all relate to the coastal environment, one makes specific reference to coastal development. This states:

Facilities for public waterfront activities should be maintained and developed. They should be complemented by opportunities for private development, particularly for development of marinas. Il

In creating a plan to accomplish these goals the City was divided into seven districts. Five districts encompass the coastal areas. The geographical bounds of each district is described in terms of population change and is subdivided into neighborhoods. Each neighborhood is described in terms of population change and existing recreational facilities. A summary is then presented for each district with specific recommendations for added land or facilities in each district. Maps show existing facilities, areas for expansion or development and specific sites for proposed new facilities.

Major open spaces are mapped for the City with four existing areas

11 Ibid., p. 7 . 
show on coastal land. Municipal open space policy is then stated. These explicit statements in effect since 1958 are:

(1) to acquire throurh gift, dedication, easement for arainage, park or for other purposes or by other means the streans, brooks, swanps, marshes and other areas which conprise the natural drainage system of the City.

(2) to retain ownership of tax deiinquent 1ots. Iots will be withheld from tax sale wherever drainare, recreatjonal or educational purposes are to be served. 1.2

The inplmentation of these policies in coastul areas has been supplenented by the development of specific waterfront development plans. Citing the economic inportance of the waterfront to Harwick's econonic base, the plan surmarizes past efforts and financing in six coastal arcas: Apponaug Cove, Conimicut Point, Oakland Beach, Warwick Cove, Partuxet Cove, Buttonivood Park.

Eight specific coastal develorment policies are then proposed:

(1) Through public investment, provide opportunities for private capital investments along the shoreline to broaden the economic basis of the community.

(2) Provide adequate municipal publjc facilities along the shoreline.

(3) Provide neighborhood bathing facilities along the shore wherever possible.

(4) Assure existing and future rights of way to the shoreline? for fishing, bathing, and other vaterfront activities.

(5) Provide public launching ramps for small. boats.

(6) Control the use of land along the shore front through zonjing. 
(7) Reserve areas along the shoreline for conservation purposes.

(8) Explore the possibilities for further navigational improverents in otyer coves of Warvici-'s coastjine 13 to meet the needs of increased boating activities. ${ }^{13}$

In addition to these policies for controlling coastal development in general and 3 the aforementioned projects in particular, eight new projects are recomiended. These are localed at: Bruch Neck Cove, Passeonquis Cove, Occupasstuxet Cove, with additional devolopment at Apponaug and Wartick Coves. A neighborhood beach concept is also aeveloped for the following locales: Nausauket Beach, Capron Farm Beach, Longmeadow-Bayside Eeach, and Sandy Point.

The report concludes with specific implementation measures bascd on two major concepts: (1) a systematic prosxan of public land acquisition; and (2) a systematic program for devcloprent of public facilit.ies. Five specific guidelines are presented to focus concept one. Detailed progrims, budgets, proposed Jegislation, and outsidie sources for funds are cited to accomplish concept two.

Though such legislation requires changes in zoning in certain locales, it is clear that preservation and enhancoment of the coastal enviroment dopends primaxily on strategic acclisition of land and strateric placenent of public services in conjunction with zoning rather than through prinary reliance of zoning to shane or encourage new development (Appenđix A, Q. 14). In teims of agents most likely to reshape this policy and piogram approach, developers were seen as

${ }^{13}$ Ibid., p. 59. 
128

the group outside government most likely to influence policy formulation. (Appendix A, Q. 4)

To judge the quility of the Plen on coastal matters, five criteria will be applied:

(1) Clarity - The Master Plan--Recreation, Open Space, and Vaterfront should rate high on the criterion of clarity ror the plan. It presents explicit goals, objectives, policies, detailed analysis and plans for coastal development, implewertation costs and programs. It recomenas legislation on the local level and proposes regional cooperation to unite Warwick with neighboring towns to solve problens that are regional in nature. In addition, the slavet Report proposes a promram of commity renewal and governmental reorganization to holp achieve coastal prozrains and policies.

(2) Internal Consistcncy - The proposals in the RP-RON are outgrowths and expansions of some of the major concepts and policies originally presented in 1956 and after. Many of the basis proposals date as far back as $19 \mathrm{l}_{\mathrm{H}}$ when the Planning Board recomrended a laritime Commission to deal with coastal concems. In addition, the Report presents ner policies and proposals which are consistent with past policies and the changes in Warrick. While maintaining continuity with past efforts these policies are designed to meet the necds of increasing population gronth. In many instances existing areas are recomonded for improvement, but in each case these improvements are based on projectcd population increases in each neighboxhool as well as overall demand for coastal uses. The clear and logical Errangement of the Report links the comcise goals and policies to indivicual proposals 
and site plans. In addition, it stresses the desirability of linking Warwick's development plars rith East Greenwich and Cranston.

Initial movement; in this direction has been evidenced by joint appropriations with these ruxicipalities for channel improvements in both the Pawtuxet and Greenwich Cove. The major reason for such improvement was seen as strengthening Warwick's economic base through additional. maxina development and appreciation of coastal land values. The Report presents a consistant approach to coastal development. The only shortcoming of the report is that it does not deliniate specific areas of ecologic importance, nor cioes it attempt to demonstrate in any other than economic terms what the relationship of Varwick's coastline is to the rest of Narragansett Bay.

(3) Scope - 1980 is the target date for this plan. All proposals for expenditures and additional regulations are based on the projected population size and derands as of this date. The CRP is also projected to be completed by this date. Though behind schedule the implementation of the plan is being accomplished.

(4) Comprehensiveness - With the exception of not dealing with ecological concerns, specifically (though marshland protection is noted) the plan and approach to coastal development is inclusive. Within the plan specific programs and actions are designed to relate pollution abatement, residential groith, regional cooporation, and commercial development to the goals of the plan. Implementation reasures are equally comprehensive in defining public and private roles in ownership and operation of municipal areas and in the manner in which these roles ere achieved. These measures include proposed controls of off- 
shore waters.

(5) Operationability - It is clear that the plan secks to establish a broad corceptual approach to coastal development in its statement of goals and objectives, but also to present a detailed plan and implementation program suitable to be immediately followed. The report outlines development areas which serve existing neighborhoods as well as the city as a whole. Though renewal of some areas is advised, this activity is presented in terms of a city-wide program for community improvement. In approaching the question of implementation maximum use of matching funds is advocated. The history of the community's interest in the waterfront as well as its past achievements in coastal improvements, such as channel-dredging and beach creation, indicates that this plan is both realistic in its approsch and use of federal. funds, but also operational in terms of appeal to the local populus who would be expected to vote on bond issues. Such bond issues had been approved in the past.

Summary: Warrick's Master Plan--Recreation, Open Space and Vaterfront clearly presents strong guidelines for both public and private action. It shows where specific public investments should be made and how these investments will be funded. This plan in conjunction with the Slavet Report indicates how the gorernment in Warrick can achieve its municipal goals for the coastline. These interrelated plans present not only a feasible proposal for the coastal lands, but also recommend a lasting mechanism for monitoring coastal change. It has high capabilities for influencing municipal policy. 
City Planning Organization and Position:

Unlike Cranston where the Charter requires the interaction of administrative personnel such as the Finance and Public Works Directors with appointed members on the Planning Comnission, the Planning Department in Warwick acts as the main technical resource and research department for the municipal government and specifically to the Mayor. By divorcing the Planning Department from immediate accountability to the Planning Board the Department is able to set and pursue development goals and to maintain long range programs of community irmprovement within the jurisdictions of its departmental authorization.

The Slavet Report proposed the reorganization of the planning and development function in response to the weakness in the Department's present ability to deal effectively with the City's problems of growth and development and for making maximum use of Federal assistance in carrying out the City's physical, economic, and social goals. The new Department of Planning and Development

would absorb the responsibilities of the following agencies: City Planning Department, Warwick Development Commission, Warwick Housing Authority and Department of Building Inspection. This new Department would also assume the responsibilities of a redevelopment agency under state law. It would have jurisdiction over the following general areas: comprehensive planning; renewal project planning; social planning; physical and economic development, including renewal, rehabilitation, conservation, commercial and industrial development; planning, development and operation of public housing; family and business relocation services; building and housing inspection. The head of the new department would serve as Warwick's coordinator for Federally-assisted programs. ${ }^{14}$

Although this proposal was narrowly defeated, it indicates the

14

Toid., p. 12. 
important role a strongly based professionel planning office is viewed as playing in Warwick's municipal government. The current Planning Director would have headed this Department.

Being closely associated with the Mayor's office, the Planning Department seeks to supply the chief executive with the technical support necessary to conceive, develop, present, and finance development plans for Warwick. To accomplish this the Planning Director, in addition to his departmental duties, acts as an advisor to the Mayor on planning and other matters. Though a close working relationship is necessary for program effectiveness, the Planning Director cited administrative staff functions for the Mayor as an activity he would willingly give up (Appendix B, Q. 41). During interviews the Director stated that he considered time spent in this manner less productive than comparable time spent in Departmental Planning activities.

The movement toward Charter reform in Warwick was based on the concept of the Mayor's office being the decision-making center for community development. Historical trends in governmental evolution attest to the centralizing of authority in the chief executive's office. The proposed Department of Planning and Development reinforces the Planning Department's close affiliation with the executive office and demonstrates the validity of the Walker position (see Chapter I, p.28) as a mechanism for increasing the impact of municipal development policies. The model for the proposed department was the Boston Redevelopment Authority. Edward Logue, former Director of that agency, was a consultant to Slavet and Levin, authors of the Slavet Report.

The willingness of the Planning Director to shed some of the ad- 
ministrative burdens of the Mayor's offjce indicates a desire on his part to maintain a degree of independence from the workings of the Mayor's office which must by necessity deal extensively with political matters. Unlike the Planning Director in Cranston, Warwick's Director feels the need for independence in formulating development plans and policies before the political implications are thoroughly assessed. By maintaining a discrete distance between political and planning octivities, plans are able to be developed without being unduly compromised. In remaining in contact, however, the Director has excellent feedback on the political feasibility of his proposals and the most advantageous position for assessing the best timing in making his presentations. It appears from discussions with the Director that he uses the natural tension existing between the planning function designed for change and the political function based on stability to advantage in achieving the acceptance of his plans. Because of the centralizing of power in the Mayor's office and the current Mayor's interest in City development, the Director is able to hamess the substential political. force of the Mayor's office to carry through his plans. In this sense the Mayor becomes his primary clientele. When conflict arises, the Director has the independence necessary to present $h_{i}$ is plans without compromising the Mayor's political stature. In such debates planning professionals under the Director are not isolated from conflict (Appendix B, Q. 32). If proposals are unaccentable to the council or public, planning functions and solutions are redefined (Appendix B, Q. 40).

The effectiveness of planning proposals depend to a large degree 
134

on the communications skill of the planning professional. In Cranston, the Planning Director was able to maintain an excellent rapport with the Mayor and Councilmen because he was keenly attuned to the political ramifications of his role as he saw it. He lacked, however, either the desire or skill to communicate or translate technical planning proposals into a meaningful guide to coastal policy formulation. The result was a low professional planning input in decision-making on coastal matters.

The technica]. planning input into coastal policy formulation in Warwick is high. It demands a high level of communication effjciency among the Planning Department and other governmental agencies and the public. Failure to have clear communications between operating agencies and boaràs in Warwick prompted the Chairman of the Waterfront Development Comission to feel competition existed between his and the planning function. All those interviewed recognized the communications gap among these and other governmental agencies (Appendix A, 0. 23).

This wis one reason the slavet Report recommended changes in Warwick's governmental structure. The nature of the breakdown appears to result from the inability of non-professionals familiar with communication patterns of individuals and groups in the political context to grasp the technical terminology and concepts of planning professionals. This gap is especially evident between the lay boards such as the waterfront Development Commission and the Planning Department. Professionals, on the other hand, appear to place very little value in creating more efficient conmuications networks with these lay boards and comissions because they feel their existance creates irefficiencies which the 
Slavet Report documents and which the proposed Department of Planning and Development would aroid. Inherent to this position appears to be an unstated desire to minimize the relevance of these lay boards by taking over their functions.

Despite the fact that there is clear evidence of the Planning Department's activities being separated from the Planning Board, the function of the Planning Board remains authorized under state enabling legislation. In Warwick this runction aprears almost entirely limited to dealing with subdivision layout and administration. This could easily be taken over by the Planning Department. In the proposed reorganization, the Planning Board would exist more as a citizens task force or subdivision matters supporting the Denartment of Planning and Developinent, rather than having the Flanning Department support the activities of the Planning Board as is now constituted.

In developing a policy for the coastal cnvironment, the semiautonomous Waterfront Development Comnission was viewed by the majority of intervievees as the agency nost competitive with the Planning Department (Appendix A, Q.2). One basis for this competition cones from the Commission's independent source of revenues in their authorjzation to issue bonds and from their position in the governmental organization. This Comission lacks any technically trained staff and reporis to the Council, while the Plaining Department with a strong professional staff reports to the lisyor. The normal friction that exists between the Mayor and Council seemingly is expressed on coastel development policy through the relationchip of the Waterfont Development Comission and the Planning Department. Conversely the motivation of these two bodies 
concerned with coastal development seems to reflect the basic split between the position of the executive functions of the Mayor's office and those of the council.

The Waterfront Development Commission (WDC) sees its function as inmprovement of existing services rather than creation of new services which is accepted as a planuing function (Appendix B, Q. 22). The chaiman of this Cormission vould depend on outside advice in attemoting to devise new approsches to the grajual change he sees his agency making (Appendix B, Q. 42, 47). The services he seeks to provide are additional facilities such as park ployground equipment and parking spaces within existing public coastal areas. The linited planning approach used by the VDC typifies the Kent position (see Chapter I, p. 28).

The WDC appcars particularly responsive to requests from councilmen to perform special tasks for constituents. Such a task might be cleaning up of litter on roads approaching public beaches. In opposition the Planning Department sees its tasks as creating new publj.c areas and services in coastal lands through a systems approach to community facilities allocations (Appenoix B, 0. 42). This aspect of planning policy formulation will be discussed in detail on the following pages.

The difference between these approaches to their functions seems to reflect both a strain between the WDC and the Planning Department as well as the City Council and the liayor. On one hand there is the HDC and Council representing the traditional care-taker axproach to municipal government, while on the other hand there is the Mayor and 
Planning Department seeking to actively manare municipal governmental. resources.

The Planning Department was established in 1952 at the urging of citizen groups within the city. The Department seeks to apply a comprehensive Planning epproach. This broad term includes environmental quality, and marine and vater resources and covers the City's entire land and vater areas. 50\% of the working budget is supplemented by Federal Funds. The complenent of personnel of three planning professionals is eugmented by as many es five graduate planning students from the graduate planning program at the University of Fhode Is land (Appendix B, Q. 22, 30,36). Employees are recruited through national planning societies and are selected on the basis of professional qualifications. Internal training is non-systematic (Appendix B, Q. 33, 35, 37).

The current PJanning Director who brought the Department to its position of prominence in Warwick's govermmental structure has an acarlemic background in ecology and is past president of the New England Chapter of the American Institute of Planners. He was a moving force behind the creation of the Natural Resources Group which was largely responsible for the establishment of a state Department of Natural Resources and more recently the Governor's technical comittee on Narragansett Bay. This group is charged with the responsibility of studying the need for a regional management mechanism for the uses of Narragansett Bay.

Many of the proposals presented in the slavet Report are the outgrowth of concepls urged by the Planning Director in his attermpt to 
utilize a systems approach in solving urban problems. The slavet Report represents one of the few examples of plarning reports which have been prepared outside the Planning Department.

The major strcngtin of the planning function can be broadly defined as the high caliber of planning professionals on a full or part-time basis; the degree of receptiveness of the Mayor's office to advanced management and planning proposals; and the public support of planning function in conflict situations (Appendix B, . 19). The major weakness of the function, in adaition to those inherent to governiental organization, are low technical ability in dealing with the many probjems the city, especially environmental and ecologic concerns (Appendix B, Q. 39); and the rapid rate of growth in the community with which the Department must contend. The town increased its number of dwelling units by $47 \%$ between 1950 and 1960. Retail sales increased $111 \%$ between 1962 and 1967. (See Chapter III - Warwick)

The proposed organization, and to a lesser degree the present organization of the planning function working in close affiliation with the Mayor's office indicates that this department seeks to utilize its high professional capabilities in concert with the centralized authority of the executive branch of government. Such organization makes possible the department's developmental approach. Planning, Strategy:

overall development strategy to dace has been succinctly defined by the Slavet Report. This report is based on analysis of the City's development activities over the last several years as vell as on a detailed understanding of the operation of the Planing Depariment and 
the Mayor's office.

In recent years Warwick has. followed a strategy which has given top priority to providing a high quality of public school education and a high priority for selected public services such us sewer and water facilities for incoming industry. As a result of this investment and the rapid rate of industrial and commercial growth, Warwick will be reaping a. tax surplus from these investments. ${ }^{15}$ The task ahead as scen by the Mayox's office is to maximize existing resources so services to the community can increase while increasing taxes a minimum amount. To accomplish this, maximum use of Federal and state funds must be used. The availability of these funds depends primarily on the effectiveness of the planning function. The slavet Report was the first step toward increasing the effectiveness of the PJenning Department and city governmant, especially the executive branch.

Geofraphically Warwick's developnent strategy has been directed toward two areas: comercial. and industrial growth along Rts. 95 and 295 in westem Warwick; and comercial and service industry growth in proximity to the expanding Green state Airport in the center of the City. A third area, the 39 mile coastal zone, is the other locale in which municipal development will certairly occur.

The Community Renewal Progran (CRP) developed by the Planning Department represents the implementition measure and development strategy for enhancing existing development and resources, especjally in coastal areas. The explicit goal of the CRP relating to Warrick's

${ }^{15}$ Ibid., p. 12. 
coastline are:

To fulfill non-residential as well as existing and new residential needs and balance development of the City's 39 mile shorefront. 16

Warwick's primary human resource development goal is:

providing al. people and families of the City with a greater variety and quality of living, including a basic parity of municipal services for all neighborhoods and residents, and meeting the needs of disadvantaged groups through specialized services. 17

To achieve these goals the CRP places strong emphasis on the improvement of housing available to low income fanilies, through the elimination of blight, and through the construction of new housing by the use of available public subsidies. Other implementation measures include encouraging the establishment of representative neighborhood groups, especially in low income areas, and establishing communication links between such groups and an agency within the municipal government which would be responsible for social planning (see Chart E).

The total implementation of the CRP is based on the conccpt of coordinating city services with the private sector. The Planning Department's strategy is built into the program itself rather than being a separate device for program acceptance. By accepting the concept of comnunity renewal in the format of the CRP, elected officials are in effect accepting the approach and program of the Planning Department. This approach differs greatly from Cranston's Planning Department which attempted to establish the values of the decision-makers in the

$$
\begin{aligned}
& { }^{16} \text { Ibid., p. } 6 . \\
& 17 \text { Ibid., p. } 6 .
\end{aligned}
$$


141

political context then designed action around them. Instead of dealing with planning issues as they arise, Warwick's Planning Department seeks to treat the City development in a systematic way. This is done by attempting to handle city problems as they relate to each other within the context of the city as many urban systems. This approach rejects the long range desirability of daily problem solving at the expense of setting up a meaningful. pattern of municipal investment of resources. It also rejects the concept of broad statements such as Cranston's Compreherisive Plan as a meaningful document witrout specific plans and programs to follow it up.

Wawick's development strategy is explicitily stated in detail by the Planning Department in the Slavet Report:

The implementation of the CRP will mean thet public actions-the construction of public facilities, the use of eminent doinain to guide development in rencra.l areos, the use of zoning to preserve the integrity of different catngories of land uses-will help to channel the private markets in housing, industrial and commercial development toward CRP goals. The City of Wamich's role in development will broacien in focus from providing traditional promotion and advisory scrvices to prospective developers of housing, industry and commercial construction to an active partnership role by ci.ty officials using eminent domain, police powers and taxing porers and rorking in close cooperation with private enterprise to realize the potential of the CRP. 28

On the basis or this statement and with the realization that the CRP is designed to deal with the conditions inhibiting development of coastal areas, the Planning Department's approach to chanee in coastal areas can be terma developmental rather than adaptive. These condi-

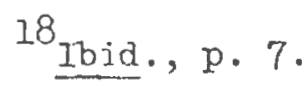


tions are extrenely small lot sizes in multiple omership with little or no public services such as sever and water. The bigh degree of professionalization and centralizing of authority which typifies the recent evolution cf the City's government lenas itself to this approach. The emphasis of the Planning Department on comprehensive planning through a systems approach coordinated with municipal investment incentives and use of regulatory powers indicates the Department employs Strategy F--strategic service alJocation--as their conceptual approach to comminity change. In addition aspects of Strategy C--systems analysis and simulation--are employed. Duxing interviers the Director stated that if the Department of Planning and Development had been created (and he feels there is still a chance), he would attermpt to formalize this systems approach with additional. staff capable of supplying technical expertise in mathemotic and computer analysis of urban systems .

Thus far the planning factor has been discussed in terms of its plan, its organization and strategy. To assess the department's capabilities or internal strengths is necessary before any conclusions can be made about the strength of planning factor in Warwick's decisionfield. To do this the same five standaras applied to Cranston's planning function will be uscd to analyze the overall effectiveness of Wamick's planning function.

(1) Central Intelligence Function - The Planning Department provides a wide range of services to Wamich. Because it is the agency Which most approxinates a research department and because of its importance in the governmental structure it is called upon to provide 
many services which include feasibility studies, procrams, advice and design services. Those that regularly request such services are real estate developers, business, residential owners, city departments, conservation groups, and the Kayor and Council (Appendix B, Q. 17, 18). The Department acts as a major link with the federal government for grant-in-aid programs. The Department appraises agencies in local government of these programs. This function tends to supplement the importance of the planning function within local government and makes the influence of planning criteria an important factor in program formulation. In defining these criteria economic, social and technical data are used.

(2) Pulse-taking Function - The Planning Department maintains close ties with the Inspection Department which supplies the planning function with data indicating detailed changes in the physical standards of the City. Such standards rould be housing conditions. Although the Planning Department issues no knom reports on these findings, it is clear these facts are reflected in the prograrns the Department deveiops. The Slavet Report recommended that this relationship be formalized by making the Deportment of Inspections a division under the proposed Department of Planning and Development. By proposing in that same. report increased communication with neighborhood groups one can see that the Planning Department is seeking to jncrease its ability to be sensitive to community sentiments as well as to the community's physical needs.

(3) Policy Clarification Function - The policy clarification function is well docurnonticd by the Slavet Report and by the raster Plan-- 
Recreation, Open Space, and Waterfront. In these reports goals, objectives, policy, programs, and implementation measures are explicitly stated. While it is evident that the Department is willing to meet with interested groups in discussing policy matters it is equally clear that the Department works primarily through the Mayor's office in its relationship to the Council. In this regard some aspects of the policy clarification are left with the Mayor's office who must defend politically the policies of its administration.

(4) Detailed Development Plan Function - The construction and Implementation of the waterfront plan is ample evidence that the Planning Department undertakes detailed development planning. All those interviewed saw the plan as well agreed upon, but felt that periodic revision was necessary because of the rapid rate of change the community was undergoing (Appendix A, Q. 13).

(5) Feedback and Review Function - The aforementioned relationship between the Planning Department and the Inspection division indicated that the feedback and review function are incorporated in the planning process in Warwick. The slavet Report in recommending a new administrative organization for city government recognized the need for constant review and sought to create the administrative machinery which was capable of responding most efficiently to public sentiment and the need for new community services. The role of the new social planning division was to fulfill this function. In terms of changes in the physical environment, most of those interviewed felt that the increased commercial development represented the most significant coastal landuse change in the community and that increasing water pollution was the 
most drastic environmental clange in the last several years (Appendix B, Q. 23, 24). Of the five criteria used to judge probable real policy impact Varwick:s Plsnning Department shows the greatest weakness in the application of this criterion.

In conclusion, it can be stated that Warwick's planning function will have a high impact on the coastal environmental change applying their present policy output. Only increased vater pollution seems to fall outside their ability to direct coastal environmental change toward their staved goals.

Summary: The Potential Irmact of the Planning Factor

The MP-ROW is a strong policy documont reflecting the strong professionalization of the Planning Department. The Slavet Report dcmonstrates the developnontal approach the plaming function secks to apply. The analysis of the Department's internal capabilities shows no major weakness. From tho above findings the potential impact of the planning factor in the decision-field can be appraised as high. The Political Factor

Because the MP-ROH presents such a strong prosram for coastal development (which has been adopted by the council) it is necessary to discuss the political factor in terms of its relationship to this plan. Historically the political factor had interacted in the decision-field in a way which had complemented the plans implementation measures. Warwick's share for initial land acquisition necessary to carry out the plan was estjmated at $\$ 166,000$. Of this, $\$ 55,000$ hal been voted by referendum in 1964 with $\$ 50,000$ allocated annually in the Capital Improvements Budget. 
Five interest groups express a distinct viewpoint on various aspects of the City's cozstal management program. Together these form the political factor as it interacts with other factors in the decisionfield.

The Waterfront Development Commission is run by a part-time director whose full-time occupation is store manafing. This commission was created in the late $1950^{\prime}$ 's as a special purpose agency to deal with coastal development concerns. It has the authority to issue bonds for acquisition and developmeit costs for developlent programs in coastal areas. The Director felt only gradual approaches by his agency would solve cosstal environmental problems (Appendix B, Q. 42.). The goal of his agency as he saw it was to provide more life amonities (Appendix $B$, Q. 22). He sav therefore the addition of recreation facilities provided by his Commission in the Oaklawn and Conimicut Beach areas as the most significant adjustment in land-usage in the coastal areas in the last two years (Appendix B, Q. 24). From intervievis it appeared that this commission's approach to coastal environmental management was defined entirely in terms of facilities. Facilities incorporating park and playground equipment were seen as being necessary in coastal areas. No thought had been given to reservation of coastal lands for future use or to analyzing who coastal users night be and what their recreational needs night be. He viewed the conservation vicwpoint as valid but not the concern of his agency. He felt the Planning Department issued nice reports but could not commicate well with the public and Council winch he considered one of the strengths of his commission. He apparently did not see any relationship between the comnunity 
Renewal Program and the MP-ROW. He indicated a strong dependence on others in formulating his own programs for coastal change (Appendix B, Q. 46,47$)$. He preferred more public land-uses in coastal areas as the best way to control key coastal properties (Appendix B, Q. 50), even though he viewed the administration of coastal programs could most effectively occur on a metropolitan scale or above (Appendix B, Q. 51, 55). Lack of dynamic leadership was seen as the greatest factor. inhibiting new ideas in coastal land-use management (Appendix A, Q. 23). He looked to the Council for this leadership in setting the direction for his Commission rather than to the Conmission itself or to the Mayor and his staff. He felt more money should be spent on coastal programs but that they had a low priority behind other local and state programs (Appendix A, Q. 25, 26, 27).

It appears the limited and passive role this commission sees itself as playing as well as the Commission's affiliation with the Council rather than the Mayor makes its potential impact in the decision-field limited to those areas about which it feels it has influence. Because discussion of equipment facility types can only occur after issues of location are determined it appears that the Commission will have little impact on primary coastal developinent decisions.

Iand omers have vigorously expressed their preferences for coastal land-use developrent patterns. They have not always had the impact they had hoped for. Land owners in such areas as Oaklawn Beach and Conimicut Point have petitioned the Council to make municipal improvements in those areas. Due to the recurring hurricane damage in these areas the council followed the recomendations of the Planning 
Department in applying to the state legislature for funds authorized under Rhode Island Shore Development Act of 1955. Although the bond issue required to raise the local matching was denied in referendum by a small margin, the City appropriated funds annually from the operating budget to gain the anount needed. This would indicate a strong commitment by the council to irproving coastal areas despite the views expressed by some residents.

Nembers of the Planning function and the Mayor's office, the force which developed the plans for these arcas, each said that as long as pianning and plan implementation occurred within the context of normal sovernicntal operation it could be effective and responsive to local residents' wishes under usual circumstances. However, if landomers becarile aroused by development plans and the idea of city hall interfering with their affairs they are capable of stopping the entire development program. It appears the slavet Report seaks to completely integrate planning into all phases of government development and by doing so make it more responsive to local opinion which was seen by all interviewed as very influential (Appendix A, Q.4).

Developers and Rcaltors were seen by the Planning Director as the group outside government which most influenced public decisions on coastal matters. Such influence is usually exhibited in the grantirig of variences in zoning cases. A.l recognized that the market inflience was expressing itself in increased conrercial and residential development in coastal areas. The Planning Director saw this as the most significant environmental change in coastal areas in the last two years (Appendix A, Q. 25). 
Developers face several inhibiting forces in attempting to exert themselves with decision-field. There are few public sewerlines in coastal areas. Decision-makers, while not against development, all expressed a concern over water pollution as a threat to Warwick's coastal areas (Appendix A, Q. 6). Developers therefore must have a thoroughly worked out plan before they will be seriously considered. The City has undergone very rapid development in recent years. Decision-nakers know that by denying development they are not in danger of being underdeveloped in the future. Decision-makers can demand quality. This discourages certain developers.

Despite these constraints Warvick is development oriented. AlI interviewed saw the function of the Comprehensive Plan, for example, as directing economic growth (Appendix A, Q. 11). Developers exext a significant impact on decision-makers.

Influential Citizens and Institutions cannot be definitively proven to have any impact on the overall coastal development, but within certain definable areas their viers are greatly respected by decisionmakers. Land omed by such citizens and institutions as the Brown family, the founders of Brown University, and the Rocky Point school. are boih listed as major open spaces for the City. It appears the City seeks to maintain these uses; both of which reflect the desires of the landowners. Should the ownership of these properties change, both could be used for many other more profitable uses. Currentily none of the lands abutting these ownerships threaten the high environmental quality of these coastal open space uses.

Elected, Appointeci and Administrative Staff in Warwick are a major 
force shaping public policy toward the coastline. Ieadership in coastal affairs has been exhibited by the Mayor's office, however, rather than by the Council. One ward Councilman said he didn't know much about the City's coastline except in his ward. The administrative leadership exhibited by these officials is supported by their academic experience which in the majority of cases was on the graduate level in public administration (Appendix B, Q. 2). Elected officials all felt familiarity with Warwick and its citizens helped them in their work. Appointed officials sought to promote only those policies which they were interested in or effected their function. In indicating the best approach to coastal environmental control strategies, the Planning Director stressed the expansion of municipal jurisdictions while the rest indicated that they would rely on others to set the strategy pattern. These views reflect their actual approach. In dealing with coastal issues these officials would seek out advice of technical advisors whose expertise lay in the areas of conservation and ecology with planners and lawyers being their second choice (Appendix B, Q. 48). Those interviewed felt that water pollution and erosion represented the types of problems that would receive the highest priority in local government. Most felt, however, that these were the types of problems that were the hardest for local policies to have an impact on. All viewed extended zoning powers and acquisition as the best way of controlling coastal land use evolution. In addition the use of tax incentives was recommended. All favored a combination of zoning and performance standards in conjunction with adjustable tax policies and penalties as a control mechanism. No clear patterns emerged as to the 
151

desirability of creating an overall administrative agency to encompass environmental concerns. All felt they would have to judge each proposal on its detailed configuration.

of the 20 itens listed in Appendix A, Question 25 on which money is spent, all interviewees felt more money was needed. As in Cranston this question appears to have solicited a response which reflected the interviewees' general concern over environmental issues, but did not reflect any detailed knowledge of the programs themselves or levels of expenditures in question. All felt that higher taxes would be the only way to finance this high level of governmental involvement. Interviewees felt special purpose bonds and general tax increases were the best means to finance these measures, though most felt that with the rising level of expenditures for all aspects of government that coastal concerns would get their share of revenues necded. Elected and administrative officials associated with the Mayor's office demonstrated the wij]ingness, knowledge and authority to influence coastal policy, while appointed and elected officials show less of an inclination to be actively concerned with this issue. Those associatcd with the Wayor's office will have a significant irmact on coastal policy formulation.

Suminary: The Potential Impact of the Political Factor

While the impact of the Political Factor can be expected to be high the views of developers and land owners can be judged as having less of an infact than those of the community leadership residing in the Mayor's office. These officials are development oriented and appear better qualified and more willing to consistantly influence the 
Council than eny other group when the broad spectrum of coastal environmental questions are vicwed. Landowners and instj.tutional users can be expecied to play an influential role on issues which directly affect them.

The Market Factor

Increased demand is evidenced for harwick's coastal lands. Resjdential and commercial uses in the form of apartments and marinas are the principle marifestation of this demand.

Two factors can be appraisea as the major constraints to the market place. First large areas of Warwick's coastline were developed as recreation homes. Many of these homes were of very poor construction, lacked inside plumbing and had through the years been abandoned. Developers find it most difficult to assomble this property for re-use. In addition the poor environmenta.]. characteristics caused by surrounding property, if assemblage is possible, tends to devaluate the developer's investment. Secondly, lack of sewage facilities poses a major constraint to high density uses. One of the aims of the CRP is to overcome these oustacles through the use of public pois ars and investments in utilities in coastal areas.

Such a plan seeks to direct development but conversely will. stinulate the market through the use of these incentives. By carefully pinpointing of where public investrents will be made the market influence is directed into predetermined uress for growth. Rather than increase existing uses the market influence is for increasing land-use capacity by establishing productive uses in place of consurntion uses. This transition is occurring. 
Sumsiry of the Irmact of the Market Factor

A leind-use iransition is occurring in harwick's ccastal areas. Turnover of coastal land is increasing both among use types such as residential units and between consurition and production uses. Denand for cosstal land is increasing generally with fartjcular variations upward depending on the qualities of a particular site. Transitions in land-use are being focused by public action into certain areas around municipal investments. The impact of this market factor can expect to increase as these investments are made and developers vie for proximity to these services, and public sanctions.

Summary of the Potential Impact of Passive Factors: Economic-Ecolosic Dichotony and Jurisdjetions and Controls

The Planning Department of Warwick has evidenced an awareness of ecological concerns and has, in their plans, illustrated areas of ecologic importance such as water courses and coastal marshlands. The Department concedes that the ecologic problems are recsionai in nature and has stimulated thinking on this level in helping establish a statewide task force to determine the best manner of utilizing Narragansett Bay as a resource. The rate of growth of the communty, however, is having a strong economic impact stimuleting intensification of landuses.

The smil parcels of coastal land held by individuals create a. major constraint to the feasibility of re-use yroposels. The municipality sceks to override this constraint through use of police and eminent domain powers. Willingness to use such controls will be a major factor in tarwick's success in following their castal policy. 
154

Such willingness will be dependent on the political repercussions this use generates. 
III. Fast Greentich, Rhode Island

The Evolution of Government and the Distriblition of Legal

Authority: A Synopsis

Government in the Tom of East Greenwich has changed little in the last two huired years. Though the government functions without a Charter, five Councilmen sustain the traditional role of tom fathers in presidins over the administration of local government. The legal executive officer is the Council. President who is the administxative head of all comittees. This formal structure is shown in chart G. Each Councilman moderates one or more committees and boards. These committees and boards, however, answer to the Council as a whole. The School Department is separate from the Council's administrative control.

Principal adrinistrative officers are the City solicitor and the Publjc Works Director. $\Lambda$ town of 8200 , Fast Greonwich is just beginning to feel the pressures of suburban growth. These alministrative officers are the most aware of this pressure because of their positions in goverment as advisors on legal and development problems. Republicans dominate elected positions. A Democrat has never held a major post. The town holds an annual f'inancial town mesting. Identification of Key Coastal Decision-llakers:

Unlike the cities of Cranston and Warwick, there is not a strict, orgonizational distinction made between policy initiators, in the form of a plannjng department and policy implomentors in the form of adminis. trative ageacies such as redevelopment agencies and watevront development comissions. Instead a selcct group representing elected, aupointed 


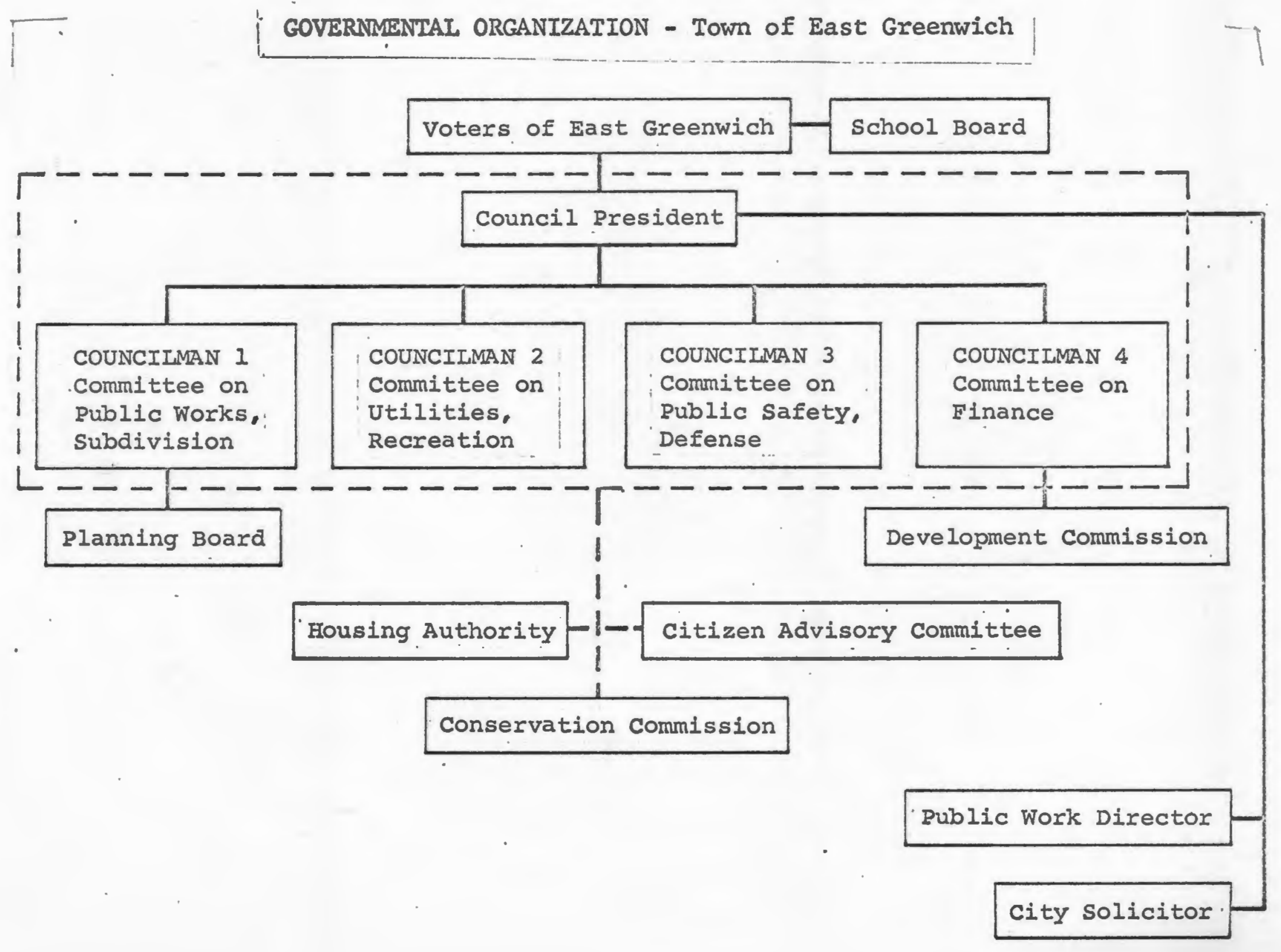


and administrative positions are seen by those interviewed as being the key policy formulating and implementing body for coastal issues. The planning board is not viewed as among this group (Appendix A, Q. 1). of these key decision-makers two are on the Council, and one each is involved with administration, and representing the district in the State Legislature. In addition, one other who could be termed an advisor to the decision-makers plays an important role in development policy. He works for the Department of Community Affairs and provides State-sponsored technical assistance to the town on development matters. Assistance includes such technical services as design and mapping as well as advice on development concerns and availability of federal funds. This group appears to collaborate informally on all development decisions. Their final position appears to determine the course of action taken by the Town.

The Planning Factor in the Decision-Field:

The Comprehensive Plan: The Official Policy Document for Management of East Greenwich's Coastal Environment Development policy for East Greenwich's limited coastal area is not meaningfully articulated in the Town's Comprehensive Plan. This plan was prepared in 1966 by the Department of Community Affairs. The stated purpose of the plan is

...to inform the citizens of the type of community which could be expected in the future. 19

The Plan contains three elements: a general land-use plan, a

${ }^{19}$ Comprehensive Plan for East Greenwich, Department of Community Affairs, December $1966, \mathrm{p} .1$. 
circulation plan, and a community facilities plan. Within these elements no significant land-use changes are proposed for the waterfront area. Instead the Plan seeks to upgrade existing facilities and uses. In short, it recommends,

growth of boating, commercial aspects, restaurants, various shops, boat sales and services, bait and tackle shops, docking, and repair and storage facilities, to blend with recreation and conservation resources of the Cove..$^{20}$

Residential uses in the area are projected as high density (4-10 families per acre). To achieve this density minor rehabilitation is recommended in the upper cove area and clearance and extensive renewal is seen as needed in the section of downtown abutting the cove. After such action existing uses are to be re-established in a modern form. Also projected is the establishment of a new circulation pattern for the shore area and the ultimate (1975 or after) conversion into a recreation area of the town dump at the mouth of the Muskerchug River which abuts Warwick on the town's western boundary.

The usefullness of East Greenwich's Master Plan as a guide to coastal development can be determined by applying five criteria. Clarity - The Comprehensive Plan lacks clarity on coastal environmental issues because it presents planning concepts and coastal environment management concepts, in particular, in such general terminology that they cannot be used as a meaningful guide to action. The Plan contains goals and objectives but these are equally meaningless. Eight goals for the community are listed. Goal one demonstrates the

$$
{ }^{20} \text { Ibid., p. } 4 .
$$


lack of focus in these statements. The goal is:

To furthier the welfare of the people of the town by helping to create an increasingly better, more healthful, convenient, efficifent and attractive community environment in which to live. 21

The Plan objective is:

To promote the welfare of the residents in the town by developing a better, more efficient and attractive environment. 22

The author of the Plan urges upgrading of existing coastal uses but offers no map or site plan for this improvement. As a result the Plan's broad statements can be seen to lack clarity in dealing with coastal concerns.

Internal Consistancy - Despite the statement that comercial uses such as boat repair and marina services should blend with conservation areas the plan recommends that the coastal area be zoned as a waterfront district favoring these commercial uses. On the only expanse of undeveloped coastline the circulation plan shows a major access road which will serve this commercial district. The effect of this road which has been built by filling part of the cove is to overwhelm five hundred feet of this natural area with a man-made feature. Such a plan and action appears inconsistent with the stated desire to conserve unique natural areas.

In the downtown area clearance is urged in coastal areas although one aim of the Plan is to maintain the historic resources of the town. The waterfront area historically was the nucleus of the town's develop-

$$
\begin{aligned}
& { }^{21} \text { Ibid., p. } 7 . \\
& 22 \text { Ibid., p. } 11 .
\end{aligned}
$$


ment patterns and yet this is not meaningfully acknowledged in the Plan. Such an oversight makes the Plan internally inconsistant. Scope - The Plan has a target date of 1986-1990. It presents no specific program for accomplishing the broad goals of the Plan. The establishment of such a target date in this instance appears fanciful.

Comprehensiveness - The breadth and all inclusiveness of the goals statements should not be mistaken for comprehensiveness. The Plan does not make reference to the community's role in environmental control, especially in such an area as water pollution. The lack of specificity as to coastal use locations, implementation measures, and delegation of responsibility in sustaining the planning program severely weakens the Plan as a useful document.

Operationability - The Plan requires many additional studies and actions in order for it to be used as anything other than a conceptual approach to community development. Interviews with decision-makers indicated that so few copies of the Plan were still available that most could not recall exactly what it said. Because the Plan is so vaguely presented it cannot be considered a meaningful guide in daily governmental operations.

Summary: East Greenwich's Comprehensive Plan is weak. It lacks specific statements and maps to indicate what form coastal evolution should follow or what public investments should be in coastal areas. It offers no guide to private investors because it does not indicate what the municipality should do or when it should occur. Town Planning Organization and Position

The Planning Board is the official body in East Greenwich charged 
with devising development plans for the town. Because there is no Charter for the town, the board functions under the mandates of the State Enabling Legislation. This legislation has been characterized by the Rhode Island Department of Commuity Affaixs as disjointed, and weak both in terms of its provisions for the role of the planning function in local government and in its provisions for zoning of local municipalities. These acts are currently being consolidated and revised for presentation to the legislature.

Two other groups officially speak out on development matters. These are the Conservation and Development Commissions. Because each of these three groups are responsible to the legislative body they take the position in government characterized as the Goodman stance (see Chapter II, p. 29). These groups scek to represent the whole public interest of the community but act as advocetes for certain functional specialties or areas of expertise. These specialties are conservation, industrial development and planning. It appears from those interviewed that the small and homoreneous size of the community gives the members of these groups a sense of knoring what the comunity wants and rejects the validity of unconventional views. In East Greenwich the viewpoint of the Democratic Party is apparently considered unconventional. The result of this splitting of advisory services on development matters reduces the impact of the planning Board.

Instead oi the conservation and industrial develorinent specialties reporting to the Planning Board who might integrate their position on issues into a plan or policy position for presentation to the Council, each group presents their views directly to the Council which has the 
option of taking one of these varied positions on a case by case basis. Those intervieved felt that the se three boards and commissions were often in conflict with each other (Appenaix A,. .3 ). None are seen as particularly influcntial in directing Council positions.

A review of the Council minutes for 1969 shows that on issues such as zoning changes where the three groums have taken differing positions, the Council showed no clear weighting of one board's or commission's position over another. On the contrary, on several instances the Council disregarded the negative recomendations of these groups to grant changes.

Despite the fact that these appointed agents of the local government represent certain functional interests it appears that the Council. utilizes their advice nore as a reflection of public sentiment on certain issues such as zoning rather than as an irput of technical expertise on a given issue. The Council ampears to depend primarily on the administrative staff, particularly the Public horks Director for technical advice.

The dispersal of the planning furction among these three functional specialties is in kecping with the tradition of small town government which evolved in the agricultural tradition of decentralization of authority. While this gives a public image of a participatory democracy, administratively it constipates the daily decision-making pro.. cess. Decisions have to be made on planning cormunity development. These are made, it appears, independently of these groups. Unlike Verrick and Crarston, relations between official government agencies such as the Vyor's office and the Planning Departnent 
do not have a significant impact on coastal policy formulation. Instead, in the small bureaucracy of East Greenwich there are certain key individuals who by force of their position and personality tend to dominate coastal development decisions. Of this group the Public Works Director has initiated most of the thinking in terms of East Greenwich's approach to coastal development. All those elected and appointed officials interviewed felt the Public Works Director is the town's planning function. The Comprehensive Plan is seen by him as a general guideline for controlling community growth (Appendix B, Q. 22). On account of the rapid change in the community the Public Works Department has sought to increase its internal technical ability through added staff. This lack of expertise is viewed by decision-makers as the major weakness of town's ability to control change (Appendix B, Q. 39).

Because the planning, decision-making and implementation functions are not organizationally based but instead located in a few select individuals what ever tension exists between the planning and political considerations appears to be controlled in the informal bargaining process that occurs as this group decides what to do. Location of these individuals at the top of the town's administrative and political structure can be viewed as the major reason for their success in carrying forward their ideas.

Planning Strategy:

One major occurance in recent years has set the pattern of actions for this group to attain public acceptance for their proposals. In 1968 this group decided that an additional boat launching site was 
needed in Greenwich Cove. A site occupied by a house was found on a steep bank overlooking the cove and a sale price of $\$ 15,000$ was established. It was the feeling of this group based on the Public Works Director's site plan that sale of the gravel excavated from the site in preparing a ramp and parking area would offset most of the development costs.

Although state $50 \%$ matching funds were available under the Green Acres Act, the group felt the requirement that the area be open to all State residents was not desirable. They believed that if Town funds were used the facility could be restricted to the exclusive use of Town residents. The proposed sum of $\$ 15,000$ was rejected at the financial Town Meeting. Seeking to move ahead with the plan, the Town officials then applied for Green Acre funds which did not require the sanction of the Town meeting. The Plan was then carried through as originally conceived by the decision-makers, despite the original negative vote of the town meeting and despite the fact that there had been no particular sentiment expressed at any point for the ramp proposal.

When queried on this point those interviewed in this group unanimously agreed that the negative expression at the Town meeting was for the amount rather than the concept of a boat ramp in the proposed location. In making the determination of this use no other alternatives were considered. All interviewed felt, despite some expressions of community that the Council had gone against the will of the people, that they had acted well within their perogatives in pursuing this plan in the manner they did. All expressed a dissatisfaction with the 
equity and efficiency of the Town meeting mechanism and felt that perhaps a charter and reorganization of government into a mayor or councilmanager format might be worthy of investigation.

It is clear from interviews that the success of the ramp and the ultimate public acceptance of this manner of Plan implementation has chrystalized a strategy approach for the decision-making group. All feel this ramp represents the most significant change in East Greenwich's coastline in the last two years (Appendix B, Q. 24). Since that time the ramp facility has been further improved and additional work such as the installation of sanitary facilities is scheduled for this year. None of those interviewed, however, feel any desire to encourage private initiative from outside the Town by using public funds as incentives.

This select group while exercising actual power cannot pursue a developmental approach to planning because of the dispersal of legal authority and lack of professional expertise. While the boat ramp plan was not specifically mentioned or sited on maps in the 1966 Comprehensive Plan, the idea fits generally into the concept of coastal development envisioned by the Plan.

Within the adaptive approach practiced by this group the ad hoc opportunist role defined on page 33 best fits the strategy used in the boat ramp issue and in their subsequent activities.

By using this approach and funds from his operating budget, the Public Works Director has been able to push forward with municipal coastal development on a project basis. Two small coastal "miniparks" are now being constructed by his department. The Director feels 
this initiative on his part and on the part. of the other decisionmakers is an efficient way to develop the Town's coastal areas for this type of use. The Director noted that he did not react in any way to criticism of his department (Appendix B, Q. 40).

Summary of the Planning-Development Factor:

Unlike Cranston and Warwick where there is a high degree of functional differentiation in the government, East Greenwich's planning and development factor is not organizationally based but rather is based on the interests and activities of certain key individuals. Unencumbered by governmental bureaucracies these individuals interact freely and are not constrained by accepted roles in the governmental hierarchy. Organizational definitions such as planner, administrator and executive officer do not strictly apply where no such organization and differentiation of authority exist in their manner of interaction. For this reason it is impossible to apply Meyerson's five criteria as a judgement of the affectiveness of the planning function's impact on decision-makers in the context of the decision-field. The adaptive approach and ad hoc opportunist strategy used in East Greenwich represents the way the Town effectuates their coastal management procedures. This is a distinct consideration from the way a planning department might devise a strategy for community development which may or may not be followed.

The Political Factor:

The political factor in East Greenwich must be discussed in terms of the way it affects the planning and development factor. This latter factor exercises the initiative on coastal issues, though the following 
Exoups express views which are considered. Aspects of the decisionmaking group are discussed in the context of the political factor. The Conservation Comission in East Greenwich is chaired by a retired state police officer. The major focus of his work is preservation of water courses in the inlarid section of the town. His views on conservation stress the John Muir tradition of the conservation ethic which upholds that the sanctity of nature should be preserved untrameljea for the future. As a result of these views all his efforts are exerted in the undeveloped part of town. It appears that key decision-makers tend to respect the views of this group only when issues which might have an environmental impact axise in these areas of town. An area of specific expertise is that of pollution in strearns. He expressed the view that the Cove is already polluted and has few conservation areas worthy of preservation. He feels the coastal areas of his Tow need complete rebulding to reflect the original environmental qualities of the area. He advocates only specific policies he is interested in, and relies heavily upon others for guidence (Appondix $B, 0.46,47)$. He favors increased regulation of the coastal zone by some higher authority such a.s a regional agency. He fecls more should be spent resolving coastal problems but looks to the state and Federal governments for initiative in these matters (Appendix B, Q. 55).

While it appears that the Conservatjon Comission has a limited interest both functionally and geographically decision-makers indicated that they vished the conservation comission would be more active, especially in coastal concerns which are of particular interest to the decision-riting group. Some of this group indiceted that the Commission 
was an excellent place to plant ideas which later became their own. Decision-makers feel it desirable to have ideas generated on conservation matters by this group but also feel they are too slow to have a real impact for the conservation interest in light of the rapid development the town is undergoing. Thus on coastal decisions their interest and impact is low.

Land Owners exert some pressure on decision-makers . Coastal landowners such as marina operators have repeatedly petitioned the council for extension of their uses but have had no noticable impact on coastal decisions. These groups and individuals cannot be considered a dynamic group willing to disxupt their smooth relationship with the Council. The views expressed by fishermen and quahoggers are not seriously considered by decision-makers, interviews revealed.

Developers and Realtors have showed little interest in East Greenwich's coastline. This may be accounted for, in part, by the highly developed and low quality of the land and buildings in the area. Influential Citizens and Institutions exert a significant inpact on coastal decisions. The Town's preservation society has recently come to life and is making a survey of much of the coastal land-use structures. It appears the growing commitment of this group to upgrading this area will preclude the extensive renewal recommended by the Comprehensive Plan.

The 20-25 member Town Republican Comittee is the second organization which has a meaningful impact on coastal decisions. From this source all those elected officials receive their perception of public opinion. While this group does not initiate action, its reactions are 
carefully arpraised by the decision-makers. Currently this Republican Conmittee is studying the desirability of urban renewal for the coastal area. From interviews it arpcars that this investigation will take several years as there are no outspoken supporters of the concept. Elected, Appointed, and Administrative Staff described in this discussion as the decision-making group shape public policy toward the coastline. Their leadership in this area is evidenced by their carrying through of the boat ramp proposal. Problems such as overcrowding in the harbor and traffic and congestion on the shore areas have prompted this group to attempt to expand their authority on coastal problems by submitting a bill to the State Legislature. The submittal of such a bill indicates the willingness of this group to press forward with their om policies and to increase their personal influence (Appendix B, Q. 46, 47). This group possesses progrcssive views on how coastal areas should be handled in the future. All feel plarners and engineers offer the best advice on coastal development matters and would consider proposing the addition of one or more of these professionals to the Iom's paycoll (Appendix B, Q. 48). All favor increased public ownership and centralizing of coastal programs into a single administrative agency. All favored more state and federal participation and funds to carry out these proyrams but each insists on strong local control (Appendix B, 0. 50,51, 55). All show a willingness to adopt now untested coastal developrnent programs, provided they do not arouse the Town (Appendix A, Q. 24).

The leadership demonstrated by this group is a natural outgrowth of their personal characteristics. Each of those elected of icials 
interviewed ruas a business. One elected official is a probable candidate to oppose Congressman Tiernan.

Sumnary: The Potential Irmact of the Political Factor

of the groups constituting the political factor only the decisionmaking eroup cescribed as elected, appoirited and administrative staff and the Town Republican Conmittee have a meaningful impact on coastal development decjsions. The decision-making group, while political in nature appears to be free from any countervajling pressure. The Narket Factor:

Coastal land use patterns in East Greenvich's shore front show litt]e evidence of being affected by market pressures. Existing uses such as marinas and boat yards are not competing actjvely for land. Done arifiquated usca such as fisherion's shacks remin as they were 35 years ago. There are no spokesren for the market factor attenpting to influence decision-nakers. Coastal land-use patterns appear stable even though the uses themselves are in dentand. There is no evidence that the market factor is making any impact on decision-riskers. on the contrary, the lack of improvement in the area has promoted some officia.ls to consider reneral as a mechanisn for stimulating market activities.

With the exception of land purchased by the town for municipal boat rarmp turnover has remained low. While land values are appraised by realtors as increasing the configuration of existing land-uses, topography, rail lines and streets appear to be inhibiting the market. Summary of the Potential Inpact of Passive Foctors: Econonic-Ecologic Dichotony and Jurisdictions and Controls 


\section{1}

The lack of market activity has not resulted in any significant movement forward of the ecologic viewpoint in the decision-field. On the contrary, demand for increased anchorages and the discharge of effluents from boats has had an effect on water quality. Though some interest has been shown in protecting and enhancing coastal lands for aesthetic purposes, water quality is not actively being monitored or improvement sought.

The lack of municipal controls evidenced by the special bill seeking to expand local control remains weak and unaggressively used. Private property rights are greatly respected; eminent domain has not been used. 
IV. North Kingstown, Rhode Island

The Evolution of Government and the Distribution of Iegal Authority.

Like East Greenwich, North Kingstown functioned for most of its civic life under a council form of town government. With the adoption of a town Charter in the early $1960^{\prime}$, North Kingstown established a council-manager governmental form. The manager oversees all administrative functions and acts as the Public Works Director. He is the only administrative professional in Town government. All boards and commissions report directly to the five man Republican Council. The town appropriates money in the annual town meeting.

Development considerations are handled by the Planning Commission which answers to the Council but utilizes the City Manager as a technical resource during the time of capital budget preparation.

Although the Town has over 26,000 residents and a professional administration it gives the impression of resisting centralized authority. Eighteen special purpose commissions composed of 90 members serve as advisors to the Town Council. Governmental structure and standing committees are illustrated on chart $H$. Some of these committees have more than eight members. There is little overlapping membership.

Despite the profusion of advisory groups there is little or no full-time organizational staff to coordinate these diverse efforts. This facet of the governmental organization is its distinguishing operational feature. The Planning Commission is the agency which most closely approximates this coordinating function. 


\section{GOVERIMENTAI ORGAIIZATION \\ TOUN OF \\ INORTH KINGSTO:IN}
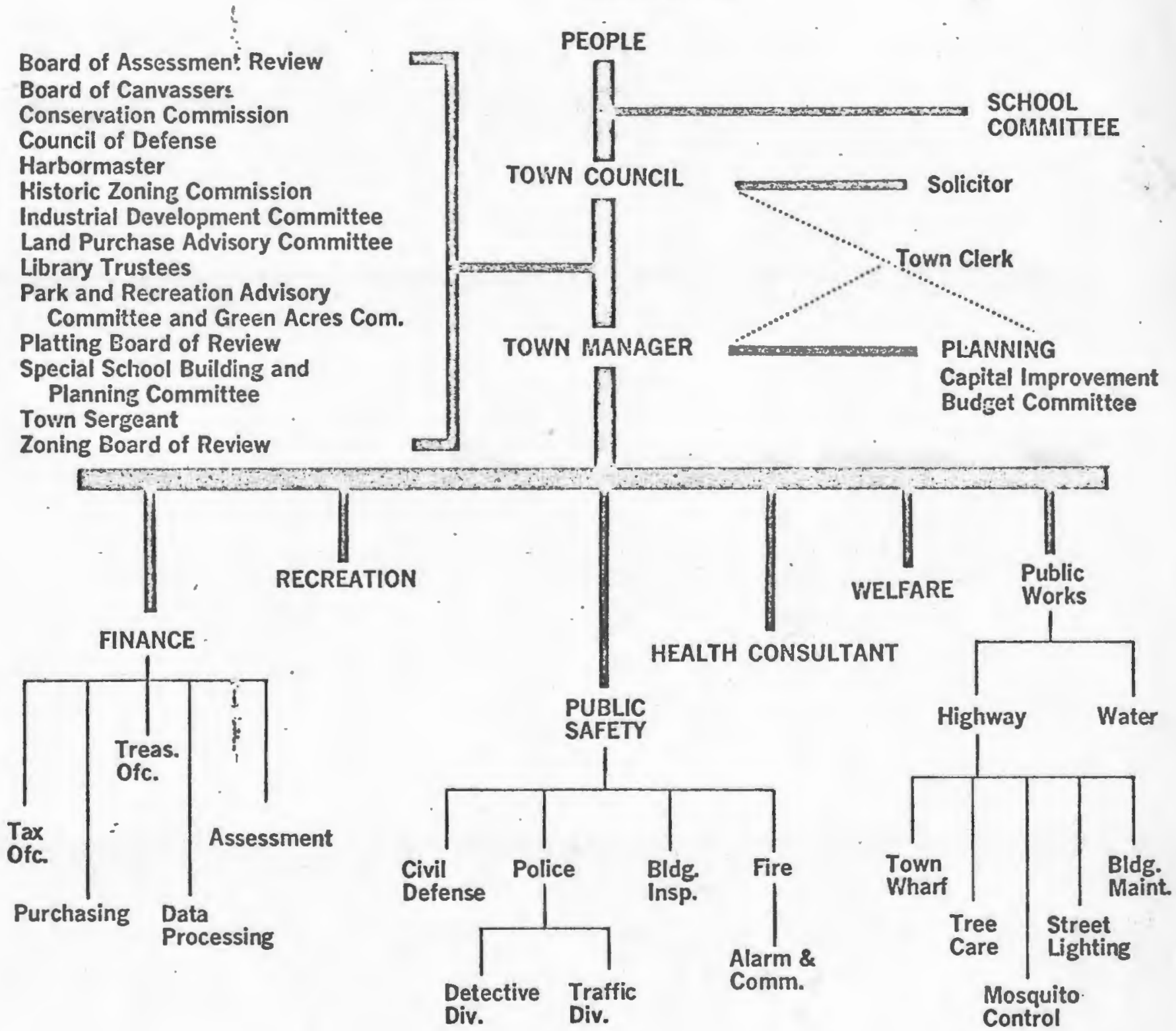

Source: Anmul Report: Tom of North Kingstown, Rhode Island City Managor's Office, 1968. 
Identification of Key Coastal Decision-Makers

The lack of communication and organization among these advisory comittees seemingly makes decision-making a highly diffused practice. All major decisions, however, are legally made by the Town Council using the advice of these groups. Officially these groups answer directly to the Council without reporting to the Planning Commission. This Commission, however, is the key locus for policy formulation discussions on coastal concerns.

As in East Greemrich, certain individuals from various advisory commissions have a particularly strong irmact on coastal development. These same individuals interact informally without reference to their particular committee assignment or elected position. As one councilman put it, "We make most decisions over the telephone long before it is taken up on the Council meeting." This informal interaction forms a comunications network which is common to all small towns yet unique in each.

On coastal issues the Planning Commission chairman is accepted by all those interviewed as being the most influential individual. others include a councilman and chairman of the Industrial Development Commission, chairman of the Conservation Commission, and the City Manager. of this group the City Manager achieves his influence by his legal authority while elected and appointed officials, though possessing legal authority, appear to have gained their influence by the impact of their personalities and their place in the local political setting. While it is possible to identify this group as key decision-makers, many individuals interacting with these few form a complicated hierarchy 
whose influence cannot be precisely determined. As in Fast Greenwich, group consensus is sought even though the basic definition of the issues being considered is usually articulated by the key decisionmakers.

The Planning Factor in the Decision-Field:

The Comprehensive Plan:

The town of North Kingstown has no Comprehensive Plan. The Rhorle Island Department of Community Affairs prepared a plan for the commity in 1958 but before it was accepted the tensions that developed between the Comnission and the state project planner negated the usefulness of the plan. Apparently the tow officials felt this state employee acted in a high handed manner in advising the town. The Plan was shelved.

In 1969 the first year class in the graduate curriculurn of Community Planning and Area Development chose North Kingstown as a study area. During the course of the year a Comprehensive Plan for the tom was developed by the class of 18 members as a study exercise without consultation with North Kingstom officials, although the class attended Commission mectings and supplemented information supplied by the town with field investigations.

Since the presentation of this report to the community at a public meeting in North Kingstorm in May 1969, no apparent movement has been made to accept or modify this document. Tho graduate planning students were hired on a part-time basis ostensibly to work with the Planning Commission detailing precise proposals from some of the concepts presented in the student report. The students, hovever, perforined drafting services for the town in transcrioing zoning classifjcations 
from plat maps; being so directed by the Planning Commission chairman.

Currently there are no studies used by the Commission to direct their position on coastal land-use policy. Town Planning Organization and Position

The Planning Commission has been functioning in North Kingstown for twenty years and is currently chaired by one of the original members. As in East Greenwich, this commission answers directly to the Council though it also works informally with the many boards and commissions associated with the government. While the Planning function occupies the Kent Position described on page 28, it uses ad hoc committees (see page 29) both as a means of deriving community participation and consensus and also as a means of generating broad based support for planning proposals. Though all those interviewed stressed how smoothly the town government functions there appears to be some competitiveness or strain between the chairmen of the Plannning and Conservation Cormissions and between the Planning Commission chairman and the City Manager.

The source of this competition appears to result from the inability of the Commission to adopt a Comprehensive Plan after twenty years of meetings. The Commission chaiman made repeated reference to the Commission's efforts to direct community growth in accordance with the Comprehensive Plan even though no such document exists. The Conservation Commission chairman noted that without a plan or data the advice of the Planning Commission on coastal or other areas was no better than the views of his commission or anyone else.

The City Manager felt that the Planning Commission had become somewhat of a government in itself in that it makes decisions which the 
Council invariably endorses but without being politically responsible directly to the citizens. He indicated that he had been unable (or unwilling) to introduce any changes into the functioning of the Commission. He felt the Commission had established an image of what planning is and that attempts on his part to redefine their manner of operation challenged them. Conversely the Planning Commission chairman minimized the importance of the City Manager, casting him as a financial technician. Since being interviewed the Manager has resigned citing frustration at his own inability to create a municipal building program which would make an impact on the development patterns of the town.

The Planning Commission chairman dominates the Cormission. In addition to his owm business as newspaper owner and editor, he averages 12 hours per week on Commission activities (Appendix A, Q. 4). He views the goals of his planning function as economic growth and provision of more life amenities. The Commission meets weekly to handle development questions. The chairman cites low budget and unexpected workloads as the major reason for gaps in the planning performance (Appendix B, Q. 39).

Despite the fact that the Commission has been unable to devise a community plan they have rarely used planning consultants or drawn on state expertise since 1958. The Commission is confident in its own ability to shape development particularly in coastal areas. This confidence is reflected in their development strategy. Planning Strategy:

Because the Planning Commission has no plan, and considers the 
land-use pattern in coastal areas fixed there does not appear to be any particular development objectives framed which vary significantly from existing land-uses. Neither are any problems in coastal areas perceived by the chairman. He did not feel that either pollution or dredging and filling were a significant problem to the town, even though the two Navy aircraft carriers stationed at Quonset Naval Air station have no shore sewage treatment and house over 800 men each (Appendix A, Q. 6).

When asked which group outside of government most influence decisions on coastal matters the chairman responded local landowners although he strongly pointed out that the Commission had the final say.

In achieving acceptance of his proposals the Commission works through many of the cormittees of government. These informal gatherings set the pattern of the planning strategy for the Commission. All are urged to express their opinions on development matters even though very little basic information is available.about the physical and social characteristics of the community. The Comnission appears to dominate the conclusions drawn from these discussions because of their accepted position as technical experts.

This expertise is reflected in the Commission's view of planning. To this group planning has a strong engineering connotation. This is how the chairman approaches his tasks. One of the Commission members is an engineer. He was appointed to the Commission as were two other members in recent years on the strong advice of the chairman. Most planning proposals brought before the Commission are decided on the merits of engineering feasibility. Decisions are made on the basis of 
the cumulative knowledge and experience of the Commission members. Ground water pollution, for example, was viewed by the chairman as the major implication of subdivision development. In coastal areas, much of which has very low density development this problem was viewed as particularly severe. Because of this view in the Saunderstorn village of North Kingstown the Cormission has required $1 \frac{1}{4}$ acre minimum lot sizes on some of these coastal lands.

The lack of overall plans for cosstal areas and the emphasis of the Planning Conmission on examining proposals individually indicates that the planning function applies an ad hoc opportunist strategy (see page 33) within an adaptive development approach. All. those intervicued felt the planning function sought to channel growth (Appendix A, Q. II). This approach, hovever, is not reflected in the I'own's zoning of coastal areas. The ordinance which has experienced minor revisions since its adoption in 194.7 leaves much discretion on developrient matters with the Planning Comission and the zoning board. These decisions are made on the basis of the Tom's linited technjcal resources in judging development proposals and in accordance with the desire of the Planning Cormission to raintain the status quo.

The Planning Cormission chairman presents a consistant and strongly held position on coastal programs and environmental control. He feels he has good information and no organizational constraints in managing the Town's coastal environment, but that any new ideas for management should be tested elsewhere before bcing adopted by North Kingstown. He believes local towns should be able to draw on the State's borroring credit for local financing of local coxstal plans, 
but that the State needs to spend less. money and more time rethinking their coastal programs (Appendix.A, Q. 23, 27).

He views state enabling legislation and local zoning powers as sufficient to handle all coastal development problems, and yet he looks to the State and Federal agencies as the best levels of government to resolve coastal problems which he believes should be remedied by educating the public (Appendix B, Q. 42, 50, 52, 55). Summary of the Planning Factor:

Planning in North Kingstown lacks organization, professionalism and documentation. Technical criteria and objectivity which were stated as being primary criteria and the most descriptive feature of the planning process appears to be based more on the personal views of the planning chairman whose conception of the planning function appears dominated by a civil engineering viewpoint rather than on broadly based community analysis (Appendix A, Q. 15). Though not actually sought out, the views of planning and engineering professionals were seen as most useful to the commission in deciding coastal matters (Appendix $B$, Q. 48). All new proposals are judged primarily on this engineering viewpoint and their relation to existing uses only within the municipal jurisdiction.

Unlike Warwick where detailed planning proposals have a significant impact in the decision-field, North Kingstown's planning efforts lack the organizational strengths, but nevertheless the factor remains influential because it is thought to have this technical competence and because it has functioned in a consistant manner with the same individual approach for over twenty years. 
The Political Factor:

The Planning Commission, especialiy the chairman, influences decisions on coastal matters not by weight of technical expertise, but rather by their interaction in the political context. The leadership role of the chairman has been discussed in this framework in determining his views toward new coastal programs. Other groups, however, play an active part in the coastal decision-making process.

The Conservation Commission's work in North Kingstown has made a sizeable impact on decision-makers. Over the past four years more than 1,500 acres of land and inland water area have been acquired or placed under easement for conservation purposes. Most of this property is located around inland water bodies. No acquisitions are currently projected for coastal areas, where the Commission chairman indicated he feels costs and the views of coastal owners preclude meaningful purchases.

Like the Planning Commission chairman, the Conservation chairman is a long-time resident of the Town and has been active in sportsmen's clubs. He is currently vice-chairman of the New England Advisory Board on Fish and Game Problems.

He feels his knowledge of the community and experience in wild life related activities gives him the basis of information he needs for making conservation decisions. He wishes, however, the University was more active in supporting technical information such as model ordinances.

In his retirement he repairs automobiles and spends 12-15 hours weekly pursuing his conservation work. He cites decline of shell 
fishing and filling of Bissell Cove and Duck Cove as the most significant coastal environmental change in the last two years (Appendix B, Q. 25).

He feels the Conservation Cormission has the most influence with the Council. This is not a contradiction of the views the Planning Commission, but rather indicates that as discussions occur consensus is reached with each group feeling its viewpoint has prevailed (Appendix B, Q. 44).

The Conservation chairman sought to increase his influence and strongly presents his viewpoints despite obstacles (Appendix B, Q. 46, 47). He feels ownership of coastal lands should be public, but that zoning and paid easements to prevent future development presents the best prospect for controlling growth in coastal areas (Appendix B, Q. $50,52,54)$. He views Federal and state agencies as the rightful initiators of coastal programs but feels they are presently poorly coordinated both locally and on higher levels. He feels towns have equal responsibility with higher levels of government but lack resources to handle problems (Appendix B, Q. 55).

When asked how effective he felt his Commission was in communicating their viewpoint to the Council he said he had always gotten along well with them. He found his hobby of repairing cars, often council- . men's cars, allowed him an opportunity to discuss town matters informally while councilmen waited.

He tends to view shore areas in terms of locales, such as saunderstown or Wickford Cove, as independent places each with a particular development pattern. He feels environmental problems could only be 
solved by public education (Appendix B, Q. 42). He values most highly the views of conservationists, economists and oceanogxaphers in devising local coastal policy (Appendix B, Q. 48).

The Conservation Cormission has a strongly expressed viewpoint which has an impact on the Council. Their efforts to date have not been in coastal areas. Because of the strength of the chairman it is likely that the conservation viewpoint will increase in impact as development in coastal areas increases, both because the chairman is respected by Councilmen, and because their conservation viewpoint is compatible with the Planning Commission's interest in slowing development.

Landowners in certain areas have a significant impact on coastal decisions. Marina and boat yard operators in Wickford Cove play a significant role in shaping decisions for that area. Their views have been supported by the Planning Conmission.

Landowners in the Saunderstown area have sought to maintain low density development which has been consistant with the Planning Commission viewpoint. Landowners are seen to have less impact in undeveloped coastal areas than developers (Appendix A, Q. 14). It was felt by elected decision-makers interviewed that if landowners were willing to sell to developers they would be unlikely to oppose development if landowners in abutting low density areas did not feel development would affect their property. It was in this manner that land between Saunderstown and the Jamestown Bridge was slowly developed from farm to single family tracts. It appears that the impact of landowners views will increase with the density of development. 
Developers and realtors are seen to have a significant impact on decision-makers even though the views of the Planning Commission often modified their proposals. In one case lot size requirements were increased from 20 to $50,000 \mathrm{sq}$. ft. Currently a nationally based real estate firm is proposing the building of more than twenty-five high income condominiums on coastal property north of Wickford Harbor. Although this involves changes both in zoning and the previous position taken by the Planning Comission on high density dwelling units, it appears the impact of the firm is having a meaningful affect on both the Council and the Planning Commission.

Armed with plans and engineering data it appears this developer is going to over-power the Planning Commission whose basis of knowledge is experience. As development pressures increase it is probable that developers will increasingly challenge the local decision-makers. A major challenge in the next decade will surely come from the Narragansett Electric Company which holds 90 acres of coastal land (see Appendix D)

Influential Citizens and Institutions:

The Navy is the largest coastal landowner in the Town. Their use of the coastline in this jurisdiction occurs independent of any local sanctions or restrictions and without apparent regard for ecological considerations. The Tow has not evidenced any interest in curbing or influencing the Navy's use of their shoreline, even though Navy land abuts shell fishing beds and is near public beaches.

Yachtsmen do not appear interested in coastal development patterns but have urged the Council to consider expansion of docking facilities 
In Wickford Harbor. Their influence appears to be defined to their interest in the Bay as a functional part of their boating interests.

Local fishermen have complained about ecological damage to shellfish beds but neither the Council nor the Planning Commission have made an effort exerting any influence to arrest existing pollution sources, even though they are considering raising the Town's minimum lot size from 20 to $30,000 \mathrm{sq}$. ft.; ostensibly to curb more pollution.

One citizen group based in the northern part of town, where most new growth has occurred has successfully pressured local government for more professionalism. Not only did they petition the Council not to accept the City Manager's resignation, they advertised on a billboard urging the Council to hire a full-time planner. Twenty-five thousand dollars has been budgeted this year for such a new Town department. If this group continues its activities it could have a great impact on development decisions.

Elected, appointed, and administrative staff described as the key coastal decision-makers have not shown leadership in directing coastal environmental issues. The lack of a Town Plan, or activity in reserving coastal lands as' a conservation resource indicates a lack of concern over the use of the town coastal areas. Present zoning allows only low density residential uses outside of Wickford Harbor. Though each in this decision-making group showed an inclination to press forward with their own points of view, none showed an active interest in North Kingstom's relation to Narragansett Bay even though the Planning Commission felt his board most active in coastal matters (Appendix $B, Q$. 46, 47). Two individuals other than the Planning chairman felt the 
addition of a planner to the Toin's staff was desirable. On coastal matters most preferred conservationistis as advisors (Appendix B, Q. 48). All shored a strong inclination for the town to share in state revenues, but $f \in w$ favored an overall adrinistuative agency to coordinate coastai programs .

Although support and initiative are looked for on the Federal and State level strong local control is urged in guiding the uses of Federal and State programs (Appendix B, Q. 48, 50, 51, 55). Iocal initiative appears low. There seems to be little willingness to create local progrens. The City Manager who might logically be expected to help create such programs said he was not much interested in what happened. to the quohaugs, indicating his attitude torard coasial environmental questions.

Summary: The Potential Impact of the Political Factor:

Key aecision-makers by personal. inclination and past action show little interest in coastal questions. Landomers express their vievpoint forcerully only when public or private action appears to threaten their holdings. The Navy acts completely independent.ly of 1.ocal considerations on environmental matters, while yachtsmen are concerned only about envirormental quality as it affects their boating interests. Developors and real estate interests are more frequently pressing for land-use changes. Only the combined vievpoints or the key decisionmakers are currently slowing their activitios. Certain local groups are pressing goverment to change their caretaker stance. Should this change occur, capabilities for considerine and acting on coastal environmental questicus should increase. Without this anange developers will 
probably feel little constraint in reflecting the unmodified influence of the market place.

The Market Place:

Coastal land in Worth Kingstom is in large parcels and is weakly controlled by zoning. Only the decision-makers constrain development activity. Harket pressures do not appear as intense as in Warwick or Cranston, nevertheless intensification of land-use capasity is being sought.

Two years ago the old Cold Spring hotel abutting the town beach came on the market. The town piurchased the property on the market for $\$ 180,000$ after a developer had bid $\$ 172,000$. After the deal was transacted the tow learned the developer had bid an extra $\$ 15,000$ thinking the parcel served by tow water and sexage.

In this instance the Town paid an inflated market price because it had no mechanism for determining market demand. The market influence is stimulated both by the proximity of the Navy base ard the University of Rhode Island which serve as generators of market activity.

The demand for coastal land will increase as the South County area grows. Developers will press for more changes in land-use capacity in response to this derand. It appears, North Kingstown will be greatly influenced by this factor because of their on lack of preparation and because of their inability to stop it.

Turnover of coastal property is increasing as Jand values rise. Because the rural character of much of the coastal area belos wichford Cove it is difficult for realtors to appraise exact increases in lana value. A tajor new use which is in regional derand, apartments, is 
only beginning to manifest a demand in North Kingstown. This demand may be a major challenge to the town's present zoning. Summary of the Potential Impact of Passive Factors: Economic-Ecologic Dichotany and Jurisdictions and Controls

Economic factors will overpower ecologic considerations which have no spokesmen in the decision-field. Low local awareness of environmental issues appears to preclude for the moment any meaningful attempt to incorporate the ecologic viewpoint into coastal decision-making. The Conservation Comission possesses the highest potential for this expression but is not actively interested in this pursuit. Jurisdictions and controls do not inhibit decision-makers who avoid use of eminent domain and resist infringement of private property rights. 
A CASE STUDY

THE PAWTUXET COVE REDEVELOPMENT SCHEME 
This case study demonstrates the interaction of the decisionfactors for a study area city in a real situation. While the manner of interaction of these factor's may be unique to this city, the issue of coastal redevelopment is pertinent to the entire study area for it demonstrates that planning politics and the market place are important factors in determining how coastal land areas will evolve.

\section{THE PAWTUXET COVE REDEVELOPMENT SCHEME}

In June 1961 the City Planning Commission of Cranston received from their consultant, Blair Associates of Providence, a comprehensive plan for the city. Among the many aspects of community development analyzed by the consultant was the desirability of urban renewal. The consultant's surveys found that in some census tracts "as much as $26 \%$ of all dwelling units in deteriorating or dilapidated conditions". The report continues, "... on the basis of preliminary surveys and the city's needs, it is apparent that urban renewal action of the most drastic sort--tearing down of structures-mis generally not the most appropriate form of renewal for Cranston. ....in addition to renewing residential areas, urban renewal should be used where possible to further the economic growth of the city, i.e., by renewing commercial areas and providing sites for industrial expansion".?

Under a section entitled "Tentative Renewal or Redevelopment Areas" the report lists several areas for renewal consideration.

\footnotetext{
${ }^{1}$ Blair Assiciates, Cranston Comprehensive Plan, June 1961, p. I-72.

I Ibid.
} 
First on the list was the

1. Pawlucket Business Center

Citing the existance of a substantial trade area which extends south to include the Gaspee Plateau on the Warwick Coast the consultants recorded, as the basis of redevelopment activity, the inadequate harbor, the demand for marina facilities, and needed community facilities. The report supported renewal recommendations on the rationale that inadequate parking and the existance of several deteriorating structures were inhibiting this area as a community center.

Another site for renewal action was the Bellefont Pond area which due to its diverse ownership pattern, inadequate parking and vacant land was described as an area of "arresting growth" which had, however, due to its proximity to rail lines and the proposed extension of the Huntington Expressway a high potential for industrial redevelopment.

The Cranston Redevelopment Agency was established in 1963 with Daniel D. Dicenzo, a civil engineer, as its exccutive director. Folloning the mandate of the state enabling legislation the agency began making surveys into the conditions of the first two redevelopment areas referred to in the Blair report. Preliminary surveys in September, 1964, of the area surrounding the Partuxet Cove established the following deficiencies:

1. deteriorating buildings

2. substandard living facilities

3. trefictic congestion

4. incomptible mixtures of land use

5. lack of parking facilities

6. inadequate street canacities and layout

7. obsolete building types

8. inacecute plating of land garcels

9. congestion and misusage of the cove area as a natural resource 
10. poor sitirg of buildings

11. loss of tax revenues

A tentative renewal area of approximately 11 acres was selected for closer analysis. This area included 69 land parcels with 49 structures and 53 owners. The 35 residential and combined residential-business structures represcnted 60 families. There were also 13 businesses and one manufacturing club, and volunteer fire stations usages in separate structures. The appraised value of this area totaled $\$ 860,244_{4}$ returning $\$ 18,464.16$ in tax revenues to the city in 1954. In making proposals for alternate uses of the area the folloring improvements were proposed:

1. A $50,000 \mathrm{sq}$. foot business building with 650 off-strect parking spaces, an increase of 595 over the existing on and off-street spaces, which was to house as mary of the 13 displaced businesses as desired spece. At the tirne of the agencies survey there were 30 enpty store fronts within the area of the proposed reneval site. 20 other businesses were in arrears in their rent.

2. A 28 story luxury apartment with parking facilities within the building.

3. Recreational facilities wihich included a yacht club, a private club renting cabanas to 400 members. The club would include an olympic sjzed salt water pool and restaurant facilities. Also to be constructed on part of the area dredged from the harbor would be marina with a capacj.ty of over 150 boats.

4. Along the northern banks of the Pawtuxet River vas to be constructed an extensively landscaped and lighted park which vould have a vista of the cove area as well as space for opeiz air concerts. 3

It was estimated that these improvenents woula return to the city a tax revenue of $\$ 167,528.59$ not including the mxina. Preliminary

${ }^{3}$ Cransion Redevelopment Authority, Cranston, R.I. 
figures forecasted the project cost to be approximately $\$ 1.8$ million with a net city cost of $\$ 480,000$. after the sale of the land to developers and after the $2 / 3$ federaj participation with renewal funds.

The general condition of the Pawtuxet Cove area assayed by the Redevelopment Agency's surveys did not come as a surprise to either local residents or the city council. In addition to the references made to the area by the Blnir report, the number of empty stores and the formation of the Edgewood Improvement Assocjates attest to the awarencss of the general decay of the area. Earlier in 1964 a published consumer analysis by the Providence Journal noted the decline of Pawtuxet business. Zoning for the area at the time was a mixture of commercial and multiple family intertwined with single family residential districts. Residential rents averaged $\$ 40$ to $\$ 80$ per month. The majority of the structures in the proposed project area were not owner occupied.

The proposed improvements for the area were the out-growths of the studies of the Redevelopment Agency's Director, Mr. DiCenzo, and his sumrer help. No detailed fearibility studies for erecting the 28 story residential structure had been made though the Director from his own professional background dj.d not estimate any particular difficulty. A rough working site plan had been prepared by the director for presentation and discussjon with Redevelopment Arency's citizen board. In order to provide the needed space for the proposed facilities it was evident that most or all of the existing structures on the site would have to be cleared. Extensive rebuilding of utilities and the harbor would have to occur in order for the plan to proceed. It was apparent 
that this was going to be a long term program even without the extensive delays inherent to Federal renewal programs. Local businessmen aware of this as well as the other aspects of the program scon became aroused at the prospect of "burldozers displacing people". Newly elected Mayor James DiPrete had met with the Redevelopment Agency's Chairman, Fred C. Kilgus, and Dicenzo and had reviewed the plan and the site. According to Dicenzo, he expressed shock at the condition of the Cove area, but remained neutral about supporting the plan.

Procedure for the submission of the plan once it had been formalized into drawings with their appropriate documentation could have followed one of two routes leading to the required approval by the Council before application to HUD for the necessary federal participation. Chart I and $J$ illustrate the procedural courses that would be followed under the normal circumstances.

\section{Chart I}

Redevelopment Agency

Votes Council HUD N.Y. city Plan Commission
Full Council

$-$

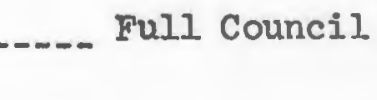

City Plan Commission
Ordinance

Committee of Council

\section{Chart J}

Redevelopment Agency

City Council
Public Hearing

$\begin{array}{lll}\text { Council Committee } & \text { Full } \\ \text { on Ordinances } & \text { HUD } \\ \text { Council } & \text { N.Y. }\end{array}$

Public 
Under the Rhode Island redevelopment law, it is the agency's perogative to iritiate renewal stuaies and to submit their findings to the city council with sucgested action. The submission of such reports could be either directly to the Council or through the Cranston City Plan Commission to the Council who then by the terms of the charter (sec. 13:03) had to refer any such proposal to the plan Comission for their recormendation. The proposed plan or idea as, it later became referred to, differed from the Blair report's recommendations in two significant ways:

1. It demended significant clearance and rebuilding while the report advocated spot clearance and privately financed conservation and upgrading of existing neighborhoods.

2. The Comprehensive Plan map of proposed lano use designated the cove area as being nedium density, while proposal suggested high density.

By October 17, 1964, Ward I councilmen within whose district the project rell were speaking out strongly against the proposal. John $\mathrm{J}$. Tuohy, Republican Chairman of the Council's Finance Comnittee, was recoried by the Providence Journal as saying,

"Apparently Daniel Dicenzo would like to push all howes and businesses into the sea just to satisfy a whim without regard to the personal rights of the people of the area. This we guarantec he shall not do."

Tuohy fuxther stated that the arency was attenrpting to "Usurp the powers of the elected City Council." in annouricing a proposed redevelopment area. Spearing to a rally of Republican candidates and workers at city headquarters John Florence, another ward 1 Councilman, pronised

\footnotetext{
${ }^{4}$ Providence Journal, octoier 17, 1961.
} 
to "fight against this plan every step of the wiy". 5 "

By early spring the forces working against the plan had mounted another offensive. Becenzo remained the sole recorded supporter of the redevelopient proposal and thus criticism was leveled at him as well as the plan. Planning Cormission Chaiman and Ward I resiojent Murray Upham who had received from the Redevelopnent Agency a request to discuss the proposal at a Commission meeting conmented publically that, "He (Dicenzo) can't bulldoze that area. He can't get government funds and he doesn't know what he is talking about, and he just got a $\$ 2000$ a year raise."6 Even Redevelopment Agency Chairman Fred c. Kilgus who had nade no previously recorded public statement concerning the plan stated that, "The plan looks intercsiting", but added that the agency would be very concerned about relocating the families who would lose their homes as a result of the renewal.

others speaking out during this period regarding the plan were Public Vorks Director and member of the Plaming Comilission Fdvin $G$. Avery who stated that it was the Council that deliniated the redevelopment area and that Dicenzo had no apparent support from his own agency. Councjunan Richard $M$. Casparian Democratic majority leader and chairnan of the ordinance Committee stated, "I don't see how other members of the agency can let him bring it up a second time after the initial

\footnotetext{
5 Providence Journal, October 15, 1664.

6 Providence Journal, Warch 24, 1965.

7 Ibia.
} 
reaction. Councilrar Cacparian later voved, "I will do everything I can to defeat j.t (the plan)." 8

On May 23, 1965, Nayor Dipretie ordered a public hearing on the proposal in Cranston City Hall. Such a hearing was within his perogative to call, but was contraxy to established procedures. The proposal, it should be noted, had not been submitted as of this time to any city agency or board, nox had the Redevelopment Agency itself taken a formal position on it or formalized the project itself into a site plan with documentation. The following sumnarizes the public positions taken on the proposal before the May 23 hearing.

BEFORE: THE HFARTIIG

Stiongly against

Counci.tmen

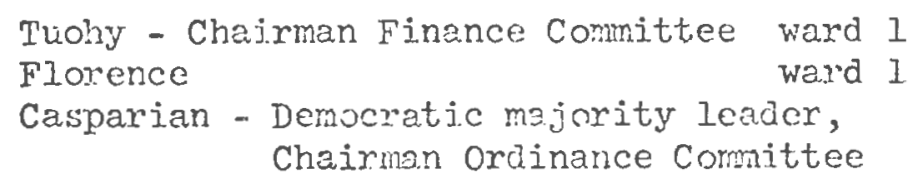

Planning Board

Chairmon Upham

Local Businessnen and cjtizens

Against

Public Works Director Avery

Councilman Goodvin

Edgewool Improvement Associations

Neutral

Nayor Difrete

Redevelopment Agency Cha.jrman Kilgus

8 Providence Journal, April 30, 1965. 
For

Dicenzo, Redevelopment. Authority Director

AFIER THE HEARIING

Stron xly Against

Mayor DiPrete

Councilmen Tuohy, Florence, Casparian, Goodwin, Marchesi

Planning Board Chairman Upham

- 12 citizen speakers

Agajnst

Planning Director Del Sesto

Spitz, Chairman of Rhode Island Area Redevelopment Committee

Neutral

Dicenzo

of the one kundred people attending the hearing only Dicenzo supported the plan. He limited his remarks to supporting the opportunity to be seized at the Pawtuxet Cove area rather than defending the merits of the plan itself. Argunents against the plan stated that the high rise s'ructure was not in keoping with the character of the area; that the plan itself not only did not serve the needs of the residents and the area, but opened up the area to out of town "sharpics" who would beriefit from federal financing in taking over the area. It was stated that the plan would bullioze the area that wasn't blighted and had not been proven to be blichted by the Agericy; that greater rather than lesser congestion would result; and finally that the Council had made no provision for such a project in the f'ive capital budgut extending to 1970 and that the plan seemed less of a plan and more of a proposition of Dicenzo.

Before the hearin: concluded the Nay and several covncilmen and 
other city officjals cane out strongly against the plan, but recognized the need for jmproveinent of the area. At the rext meeting of the Redevelopment Agency the Brard passed a resolution postponing further action on the program and directed their attention to the development of the Bellefoni Pond Industrial area.

The Planning Factor

other than the reference in the Comprehersive Flan to upsrading the Pawtuxet Cove Comercial area no mention or gujdelines were set by that document or by the Planning Department to aid the Redevelopment Authority in devising a redevelopment progran for the area. Indeed, before Decenzo was able to fully discuss his proposals with public officials his preliminary ideas mich he had used as a point of discussion becanie solidified in the public eye as "the Plan." Prior to this public disclosure he had not conferred with the Planning Department on the merits of the scheme.

Neither those for or against the proposal macie mention of the possible impact of the plan on the City of Warvick whose municipal. boundary defined the cove siae of the project.

No apparent coperation in coastal development schemes was in evidence betreen the two towns even though they had jointly appropriated funds for improvernent of the cove itself.

As far as the plan was defined no measure had been made of the impact of the scale of the proposed desjegn on the surrounding area.

In surmary, the plan as prematurely defincd lacked the detail to answer some of the most poinied criticisms against it. It was less of a plan than a schene. 
The Political Factor

No group for or against the plan expressed any opinion as to the effect such a high land-use capacity might have on the Parturet cove as an ecological assct. The Conscrvation Commission took no position. Isand and business owners so vocally supported their views that the plan was corpletely stopped and the Redevelopment Authority discredited. Potential developers did not enter into the debate, even though the Redevelopment Authority Director had interested a liew York concern in the jiea. This concern had developed similar plans elsewhere but was awaiting local public support before taking any concrete action in supporting the plan.

The Edgewood Irmrovenent Association, composed of local businassmen actively worked against the plan. They were the only local citizen organization which expressed a view and were thought to be the group that urged the Mayor to hold a public hearing. I'his organization had a significant impact in the outcome of the plan proposal.

With the exception of the Redevelopment Authority Director, all elected, appoirited and administrative officers in local government. followed the caxly lead set by coastal ward councilnen and finally the Mayor and opposed the plan. No leadership was demonstrated in attempting to reach a compromise position. In that election year all these officials responded only to the lead set by the elected council in opposing the plan. Each overlooked the recommendution of the Comprehensive plan to upgrade the area through redevelorment. Only the Redevelopment Direcior attemcted to implement the plan. 
The Market Factor

Because the area evidenced'no signs of the market influence in making the area a suitable locale for local business, the Redevelopment Director sought to stimulate the market with public investments in the area. When this effort was defeated business volume continued to drop. The outside developer who tentatively sought to participate in the plan felt, according to the Redevelopment Director that a profit could be made if the scale of the development was large enough to overcome the major deficiencies to the area. Location was seen as the major reason why such investment would be profitable. 
VI

REGIONAL CONSIDERATIONS 
Three case studies found in Chapter 5, and Appendices $C$ and D present narratives on coastal environmental issucs which have regional considerations. In each case participants argued for and against proposals even though exact benefits and costs were not systematically defined or a.cknorledged.

Public planning is the mechanisn designed to sort out these benerits and costs so that a clear and common ground of understanding can be used by decision-makers

A central feature of each case which precluded achieving this cormon ground is the widely varying fewceptions held by participants of what impact coastal resource use would have regionally. The basis for these differentiated perceptions rests on the varied definitions applied to coastal resources.

Historically natural resources have been considered comoiitijes to be consuned as part of the ecoromic grouth process. In recent ycars with the national movement toward a certiary econonic orientation, this tradjtional definition has come into question. In an urban society, amenity resources such as air, water, and open space ore becoming increasingly scarce. The coastline provides a transition point between man-made environments and the natural environment.

The shoreline possesses high value as an amenity resource but it is partjcularly susceptible to the effects of externalities. The impact oi these exiernalities resulting the $\in \hat{f}$ fect of the market factor

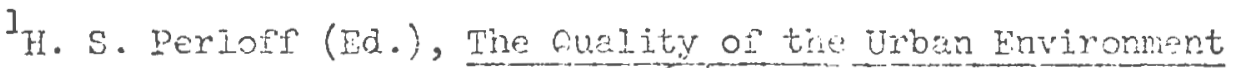
(Baltinore: Johns Hopkins Press, 1069), p. 5 .
} 
is not limited, in rost cases, to a particular municipal jurisajiction. The Pantuxet Cove Scheme (Chapter 5) was seen by participants as an issue with only neighborhood significance. The Redevelopment Authority Director sought to utilize the amenity value of the coastal enviroument as a stirulus for economic revitalization. He did not consider the external eff'ects such a development might have on Warwick's coastal environment, and particulariy on the spatin]. quelities of Pawtuxet Cove and adjacent lands. He appeared to relate his extensive rebuilding proposal only to the narrow objective of upgrading the small comercial area without taking into account what effect the physical scale of the 28 story apartment tover and ancillary uses would have on the cove's or coastline's total amenity resourcc value.

Though the Director had an image of the cove which allowed him to utilize the amenity resources of the area as a basis for his plan, local residents, politicians and planners vicwed the proposal in much narrower terms. The coastal. environmental resources of the area appeared to be perceived only as land, which despite its proxinity to the amenity resources of the coastline was seen to possess no unusuel value outside that placed on it by the owner.

Politicians viewed the proposal only in terns of its impact as an election issue. Potential improvement of the environment of the cove appeared to be completely ignored as a by-product of the proposal's intent to ungrade the comercial uses. In no recorded instance did any participant feel the proposal would have a nogative environmental effect on the coastal ecology.

Rejection of the proposal appeared to be based on at least the 
following factors:

(1) The degree of local opposition, and lack of support;

(2) The degree of initiative expressca by the Redevelopment Authority Director which was vieved as an encroachment on Council perogatives;

(3) The desire to squelch an issue whj.ch would arouse public sentiment during an election year.

The Jomestom Refinery Case (Appendix C) presents the largest coastal. enviromental controversy yet faced by the West Bay Area Communities. The record is a clear statcment of the economic-ecologic dichotony. It is in this dichotomy that the basic shift in the definition of resources is most clearly demonstrated.

Those favoring the establishment of the Refinery appeared to vicw the Bay as a coimodity resource. The highest and besi use of its environmental resources were seen to be used (or consumed) as one primary basis for economic development. Despite a history of oil spillages, the inpact of new jois and tax revenues overwhelned Jamestown and state politicians.

The deepwater characteristic of the West Narragansett Bay made feasible such a proposal and yet despite the obvious positive economic benefits there was no mechanism for determining the economic and environmental liabilities.

Only the Jamestown Inmrovement Association and its supporters sought to represcnt the ecologic-envirormental vievpojnt. This point of view perceives the coastline as an amenity resource which could not be separated from the morine resources of the Bay itself. Specific functionally specialized organizations tended to be 
narrowly concerned with the refinery proposal. Chart $\mathrm{K}$ indicates some of these views on how the Bay resources should be viewed. While the strict distinction between commodity and amenity resource definitions was not made explicit, it is clear major participants viewed the proposal in these terms.

Chart $\mathrm{K}$

Commerce Oil Refinery Case

Participant Positions on use of Coastal Resources

\begin{tabular}{|c|c|c|c|}
\hline Participant & $\begin{array}{l}\text { Major } \\
\text { Activity }\end{array}$ & $\begin{array}{l}\text { Resource } \\
\text { Value } \\
\text { Position }\end{array}$ & $\begin{array}{l}\text { Position On } \\
\text { Resource Use } \\
\text { As Proposed }\end{array}$ \\
\hline Navy & $\begin{array}{l}\text { National } \\
\text { defense }\end{array}$ & $\begin{array}{l}\text { Commodity } \\
\text { uses as } \\
\text { functional } \\
\text { support }\end{array}$ & $\begin{array}{l}\text { Functional } \\
\text { conflict }\end{array}$ \\
\hline $\begin{array}{l}\text { Rhode Island Development } \\
\text { Commission }\end{array}$ & $\begin{array}{l}\text { Economic } \\
\text { development }\end{array}$ & Commodity & $\begin{array}{l}\text { Economic re- } \\
\text { turn to state }\end{array}$ \\
\hline Jamestown Tow Council & $\begin{array}{l}\text { Representing } \\
\text { host locale }\end{array}$ & Commodity & $\begin{array}{l}\text { Local eco- } \\
\text { nomic return }\end{array}$ \\
\hline $\begin{array}{l}\text { Jamestown Protective } \\
\text { Association }\end{array}$ & $\begin{array}{l}\text { Representing } \\
\text { owners }\end{array}$ & Amenity & $\begin{array}{l}\text { Iocal \& re- } \\
\text { gional amen- } \\
\text { ity cost }\end{array}$ \\
\hline Governor Roberts & $\begin{array}{l}\text { Representing } \\
\text { state admin- } \\
\text { istration }\end{array}$ & Commodity & $\begin{array}{l}\text { Political \& } \\
\text { economic re- } \\
\text { turn }\end{array}$ \\
\hline Commerce Oil Corp. & $\begin{array}{l}\text { Profit- } \\
\text { making }\end{array}$ & Commodity & $\begin{array}{l}\text { Investment } \\
\text { return sup- } \\
\text { port }\end{array}$ \\
\hline Newport City Council & $\begin{array}{l}\text { Representing } \\
\text { locale }\end{array}$ & Amenity & $\begin{array}{l}\text { Economic } \\
\text { liability }\end{array}$ \\
\hline $\begin{array}{l}\text { North Kingstown Town } \\
\text { Council }\end{array}$ & $\begin{array}{l}\text { Representing } \\
\text { locale }\end{array}$ & Amenity & $\begin{array}{l}\text { Amenity } \\
\text { costs }\end{array}$ \\
\hline
\end{tabular}


At the heart of the conflict lies the economic-ecologic and the commodity-amenity dichotomy. The lack of an institutionalized body to meaningrully dotemine costs and benefits precluded any bargaining to resolve the issue. Instead jurisdictional and functional control mechanisms all reviewed the proposal from their narrow breadth of interest.

The potential environmental conflict was left to be resolved not by public leadership or rational and comprehonsive action on the part of a public agency but instead in the raw exercise of power. In this instance, the type of development proposal required the ultimate legal. sanction by the federal government on a naryorily defined functional basis. Local regiona]. environmental impacts were considered only by indivicuals based regionally who were able to spontaneously forge a political force froin local groups with cormon concerrs. Public resource policies on the local, state, and federal level played no part in the outcome of the case.

The Rome Point Case (Appendix D) illustrated the basis for a future regional environmental issue. Local decision-makers in North Kingstour appear to anticipate few environmental liabilities when compared with the massje economic benefits inherent to the project. Though the greatest threat to coastal environmental quality was secn to be thernal. pol.lution, complete faith by North Kingstom officials was placed on the state and feceral govermments fox protection of coastal erivironmental quality.

Unlike the other cases which occurred serersil rears aco, participants from all cities ard toms recognized tho potential impact such 
a development might have on the Bay as an amenity resource. City interviewees showed a greater concern for this potential resource cost than did town officials. The use of the Bay water as a coolant was not viewed by local officials as detracting from the environment of the Bay as a local or regional resource.

Only one official of the many interviewed considered the proposed power plant from a regional development viewpoint. This Planning Director stressed the impact of the scale of development as having a potentially detremental environmental effect by establishing a precedent in the type and scale of the development. This particular proposal, he felt, will draw heavily on the amenity resources of the West Bay Coastal area. As in the refinery case, market demand for the Rome Point site was not evident for competing uses of a similar character. The site offered particular attributed conceived as consumption resources by the developers.

Summary of Case Studies:

In the first two cases public planning on the state or local level had no active role on the issue resolution, even though the Pawtuxet Redevelopment scheme was based on a coastal policy document. Although these cases had strong regional impacts there was no coordinating mechanism to relate local and regional viewpoints or to define the hierarchy of issues for these geographic areas. No public policy on the local, regional or state level was used as a standard for judging the overall desirability of these proposals.

Political factors played a critical role in the resolution of these two cases. The impact of landowner's viewpoints appeared to turn senti- 
ment against the proposals. In both cases the developers (the Redevelopment Agency and the Corporation) initiated the issue but finally succumbed to political and fiscali constraints. In these cases local and regional leadership responded primarily to political and economic factors but did not seek out a planning viewpoint.

In each study ecologic factors were poorly expressed and able at best only to inhibit the market factor. There was no standing organization or institutionalized body presenting the ecologic perspective even though ecologic harm in the refinery case was considered a major point of contention.

Fragmented jurisdictions and controls located in such bodies as the Jamestown Town Council, the Navy, the State Division of Rivers and Harbors, and the Corps of Army Engineers dealt with the proposed refinery in an uncoordinated manner and from many independent perspectives.

The Pawtuxet Case demonstrates how despite the presence of planning resources, local political factors can have a great effect in shaping development patterns which have regional inplications.

The Refinery Case is significant because it shows that when a large scale development proposal was made which used regional environmental resources no local, state, or federal public agency had the authority to review the project as a whole to determine its impact on coastal resources.

The Rome Point Case illustrates that future regional environmental issues are emerging which have the apparent support of the local decision-makers, but not the endorsement of municipal neighbors. Al- 
though interviewees expressed a willingness to cooperate in coordinating development plans among coastal communities, no formal mechanism is currently available for this purpose. The state was seen as supplying only limited technical services.

Based on the emerging national awareness of ecological problems and the formation of such local groups as Ecology Action for Rhode Island it is likely in the resolution of this case that the ecologic viewpoint will be an important factor swaying decision-makers. 


\section{VII}

SUMMARY AND CONCIUSIONS 
Coastal environmental issues as explored in this study have resulted primarily from coastal land-use proposals. These proposals were inspired by the lack or presence of influences initiated by the market factor. These influences appear to have two types of impacts on the overall development of the Study Area.

On the local scale development decisions, such as proposed intensification of dwelling capacity in Cranston, mini-park and boat ramp development in East Greenwich and proposed condominium housing in North Kingstown are locally oriented coastal changes. Extended through time they create a cumulative development pattern which changes the current environmental pattern of the total shoreline in the study Area.

On the regional scale certain proposed developments would have an immediate impact on the local and regional environmental development patterns. Such proposals as oil refineries, large high-rise apartments and a nuclear generating station have lasting environmental consequences which go far beyond local jurisdictions. While it is impossible to factually judge the effect of the proposals from currently available information, one can conclude as a result of this investigation the ability and interest exhibited on the local and regional scale in determining how such coastal issues should be approached. In addition, one can draw certain conclusions concerning which factor in the decision-field appears most capable of directing coastal management policy to reflect its point of view.

Chart I sumarizes decision factors influencing study area manicipalities. 
Chart I

Summary of Decision Factors Influencing Study Area Municipalities

\begin{tabular}{|c|c|c|c|c|}
\hline \multirow[b]{2}{*}{ Governmental Form } & Cranston. & Warwick & $\begin{array}{l}\text { E. Green- } \\
\text { wich }\end{array}$ & $\begin{array}{l}\text { N. Kings- } \\
\text { town }\end{array}$ \\
\hline & $\begin{array}{l}\text { Strong } \\
\text { Mayor }\end{array}$ & $\begin{array}{l}\text { Strong } \\
\text { Mayor }\end{array}$ & $\begin{array}{l}\text { Town } \\
\text { Council }\end{array}$ & $\begin{array}{l}\text { Town } \\
\text { Council }\end{array}$ \\
\hline Executive Authority & Centralized & Centralized & Diffused & Diffused \\
\hline \multicolumn{5}{|l|}{ Planning Factor } \\
\hline PIan & Weak & strong & Weak & None \\
\hline Position & WaIker & WaIker & Goodman & $\begin{array}{l}\text { Ad Hoc } \\
\text { Comm. }\end{array}$ \\
\hline Strategy & Adaptive & $\begin{array}{l}\text { Develop- } \\
\text { mental }\end{array}$ & $\begin{array}{l}\text { Iimited } \\
\text { develop- } \\
\text { ment }\end{array}$ & Adaptive \\
\hline Professionalization & Weak & Strong & Moderate & Weak \\
\hline \multicolumn{5}{|l|}{ Political Factor } \\
\hline Impact of: & & & . & \\
\hline $\begin{array}{l}\text { Waterfront or } \\
\text { Conservation } \\
\text { Cormission }\end{array}$ & None & Weak & Weak & Weak \\
\hline Landowners & Strong & Moderate & Moderate & Moderate \\
\hline Developers & $\begin{array}{l}\text { Increasing- } \\
\text { ly strong }\end{array}$ & $\begin{array}{l}\text { Increasing- } \\
\text { Iy strong }\end{array}$ & Weak & $\begin{array}{l}\text { Increasing } \\
\text { ly strong }\end{array}$ \\
\hline $\begin{array}{l}\text { Local Ind. or } \\
\text { Inst. }\end{array}$ & Weak & Some strong & Weak & Weak \\
\hline official leadership & Heak & strong & strong & Weak \\
\hline
\end{tabular}

Economic-Ecologic

Dichotomy

Jurisdictions

Constraints

Primary influence

on coastal policy

secondary influence

on coastal policy

Regional Awareness

\begin{tabular}{|c|c|c|c|}
\hline $\begin{array}{l}\text { No aware- } \\
\text { ness }\end{array}$ & $\begin{array}{l}\text { High Aware- } \\
\text { ness }\end{array}$ & $\begin{array}{l}\text { High Aware- } \\
\text { ness }\end{array}$ & $\begin{array}{l}\text { No Aware- } \\
\text { ness }\end{array}$ \\
\hline Landowners & $\begin{array}{l}\text { Official } \\
\text { Plan }\end{array}$ & $\begin{array}{l}\text { Official } \\
\text { Leadership }\end{array}$ & Iand owners \\
\hline Developers & Developers & Landowmers & Developers \\
\hline None & High & Iimited & None \\
\hline
\end{tabular}

Using Chart I and the preceding analysis in Chapter IV certain conclusions can be drawn regarding the degree of urbanization of these communities and the manner in which they are formulating coastal policy or reacting to decision-making factors.

In North Kingstown, the least urbanized municipality, coastal policy and governmental organization seek to create consensus through 
214

citizen participation, diffused authority, yet single party control. New and transient residents are-beginning to challenge this pattern of traditional decision-making. The town has no coastal policy. Neighborhood groups influence action toward the town's total coastal resources.

East Greenwich also has strong party control but a higher degree of professionalization. Increased development pressure town-wide is forcing the tightly organized decision-making groups to recognize that increased professionalism is necessary to handle the problems of coastal change. Coastal policy remains as an outgrowth in formal interaction between professional and elected officials. The coastline is treated as a whole or single resource as a result of the professional imput of a full-time development official, the Public Works Director.

Warwick exhibits the most urbanizing segment of the study area. It is here that professionalism has reached its peak resulting in strong local coastal policy spanning all of the city's coastal areas but also resulting in increased tension between professionals and politically appointed lay boards and some elected officials. This is manifest in a conmunication gap. It is in Warwick that planning has both the greatest impact and the greatest conflict with the political factor.

Cranston's coastal areas have long since been urbanized, resulting in a segmenting of the city's shore resources into an entrenched political clientele which seeks to represent this neighborhood interest through a machine style political interaction with elected officials. Planning impact and a unified coastal policy are weak before this factor. 
Planning - With the clear exception of Warwick's planning function, the planning factor locally has a weak impact on coastal changes. Where centralized authority exists the planning factor has not utilized this potential asset to frame development approaches. Planning has been ineffective in formulating coastal development objectives and strategies for achieving them. There is no operative regional dialogue, communication between professional officials in neighboring towns on a sustained basis, or active professional leadership coordinating development among municipalities. Planning, as now practiced, appears capable of dealing with coastal areas only incrementally with little coordination or assessment of local resources in and among jurisdictions.

Politics - Political leadership for dealing with regional coastal management proposals is not in evidence. Politics for spokesmen of the political factor remain functionally based in such groups as yacht club members, local landowners, and developers. Personal values and a narrow scope of perceived responsibilities appear to preclude local politicians from having a significant impact on a continuing basis on regional issues. Voter appeal and increased tax revenues are clear motivating forces to elected decision-making outcomes. For this reason where there is no major upheaval in the local political system politicians favor production uses which create tax revenues. Such uses are not open space and low density residences. Regional environmental considerations are not seriously considered when local tax and voter support favor higher uses.

Consistent with this impact locally on the converse side is the local Conservation Commission which advocates open spaces but cannot 
justify it fiscally under usual circumstances. Weak as they are, they have no regional organization or viewpoint. Conservationists seek to promote the natural coastal environment as an amenity resource but have little power on a regional basis to overpower large scale economic users of these resources.

Landowners exert only local interest in the majority of cases. The economics of development require regional market studies making developers a primaxy holder of regionally-oriented data.

The market factor for coastal land expresses an increased demand for higher uses throughout the study area, but is not expressing this demand in an integrated market. Local land-use patterns, laws and environmental quality appear to segregate this market factor into local sub markets. Demand is expressed almost exclusively for residential and marine oriented commercial facilities. Lack of comparable data among municipalities precludes a thorough locational analysis of market effects on land values.

Economics overwhelms ecology. There is no institutionalized ecologic viewpoint. It has been ignored until recently. There are no ecologic facts applied that are being translated into forms useful to countering regional scale development proposals.

Jurisdictions and controls reflect the varied uncoordinated approaches of single purpose agency and governmental units. Local controls in some instances can be effective. An Overview:

The market factor is the primary force from which other factors in the decision-field derive their stance. Coastal policy expressed in 
documents on zoning is a weak constraint to market factors in undeveloped areas. Historical land-use patterns and present landowners constrain the market factor more than do planning, ecological, or jurisdiction and controls.

Such controls seek to control land-use and density, neither of which relate to particular areas of high amenity value or ecologic importance. Coastal resource amenity value, a basis in economic development, is not being seriously recognized by municipalities. General awareness of local coastal environmental patterns is not translated into regional arareness of the Bay as a resource totality.

The market acts on a regional scale while countervaling factors such as politics and planning are locally operative. Consumption uses have local impacts but are acted upon by regional economic forces. Increasing land-use capacity urged by the market factor works against sustanence of open spaces and coastal amenity areas. Public policy is not maintaining coastal open spaces and general public accessibility to the coastal environment. Town officials respond to productive uses as a tax resource generator and show little or no ecologic awareness. With the exception of Warwick, public policy for coastal areas is formed without a regional awareness and reflects those factors that are vigorously presented. Policy formulation and quality depends more on the expertise and communication skills of the participants than it does on placement or particular agencies in government or the cormunity. 
Alexander, L.M. Narrargansett Bay: A Marine Use Prorile. Geographic Branch, office of ivaval. Research, Washington, D.C., June 1966.

American Insititute of Planners. Handbook. Chjcago, 1968.

Anderson, J. "Charter Reform in Municipal Government in Varwick." Unpublished Report, Bureau of Government Research, University of Rhode Island, 1069.

Babcock, R.S. The Zoning Game. Madison, Wisconsin: University of Wiscons in Press, 1969.

Banfield, E.C. and J.Q. Wilson. Cj.ty Politics. New York: Vintage Books, 1963.

Barlowe, R. Land Resource Fconomics. Englewood Cliffs, New Jersey: Prentice-Ha11, Inc., 1950 .

Bauer, R.A. and K. J. Gergen. The Study of Policy Formulation. New York: The Free Press, 1.568.

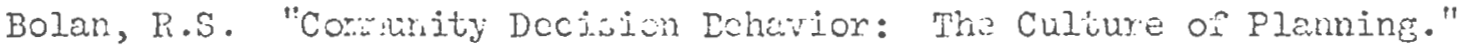
Journal of the American Institute of Plamers, 35 (Sept. 1.969), 87.

. "Fmerging Vievs of Plaming." Journal of the Amcrican Instijute of Planners, 33 (Juli 1967), 2ili.

Boulding, K.F. "Economics and Ecoloey." Future Environments of North America. Edited by F.F. Darling and J.P. Tilton. New York: Natural History Press, 1966.

Campbell, A.K. and J. Burkhear. "Public Policy for Urban America." Issues in Urban Economics. Elj.ted by H.S. PerJoff and L. Wingo. Baltinore: Joins Hopkins Press, 1958.

City Clerks Office. City Government in Cranston: 1950-1970. Cranston, R.I.: Ofice of the City Clerk, 1969.

Clausan, E.J. Cranston - An Historjcal Sketch. Providence: T.S. Haminond $\mathrm{Co} ., 190 !$.

Comission on Narine Scicnce Engineering and Resources. Our Nation and the Sea. Washington, D.C.: U.S. Goverment Printing OPice, $190 \overrightarrow{9}$.

Cranston Bicentennial Comittee. Cranston Bicentennial, 175t-1954. Cranston, R.I., 195!.

Cranston City Planning Comission. Comorehensive Plan. City of Cranston, R.I. Euited and prepared by Blair Associates. Providence, R.I., 1961. 
- A Develomment Concept for Vestern Cranston. Edited and prepared by Universal Ensineering Corporation. Boston, $19,68$.

- Capital Budret for the City of Cranston. Edited by Blair Associates. Providence, R.I., 1962.

Dahl, R.A. Pluralist Dewocracy in the United States. New York: Rand $\mathrm{McNa} 1 \mathrm{Iy}, 1,06$.

Daughters of the American Revolution, Pettaquamscutt Chapter. "Facts and Fancies Concerning North Kingstown." (Mjmeograph) North Kingstown, R.I., $19+1$.

Department of Heal.th, State of Rhode Island, Division of Water Pollution Control. Map, Present Classification of Vater quality - Sources of Pollution. Providence, State of Rhoce Island, 1967.

Doebele, W.A. "Techniques for Stimulating and Controlling Physical Development," Paper delivered at the Fourth Working Conference on Metropolitan Planning and Regional. Development, Joint Conter for. Urban Studies, Metropolitan Planning Courcil. Boston, June 1965.

Dowi, A. Inside Eurcaucracy. Eoston: Jittle Brum Ca., 1967.

Dror, Y. Public Policymahing Reexamined. San Francisco: Chandier Press, 1968.

- Policy Analysjs: A Theoretical Framework and Some Pasic Concepts. Santa Konica, California: The Rand Corporation, July 1969.

Dyckman, J.W. "Planning and Decision Theory With Extensive Bibliography." Journal of the American Institute of Planners, 24 (Nov. 1951), 211.

East Greenich Planning Board. Comprenensive Plan for East Greentich. Prepared by the Rhode Island Department of Cormunity Affairs. Providence, R.T.: State of Rhode Island, 1966.

Friedmann, J. "Regional Development in Post-Industrial sccicty." Journal of the American Institute of Planners, 30 (May 19ót), 71.

Galbraith, J.K. "The Claims of the Connuity Against Those of Economics." Specch from the conference, ov People and Their Citics," sponsored by Urban America Inc., Tashington, D.C., Sept. 1966.

Gee, W. Social Science Research Hethods. New York: Appleton-Century Crort, Inc., 1950 .

Goorman, i.I. and Feunds, Edibcos. Frincipals enci Practives of Urban Plaming. Waskington, D.C.: Interietional City Wanecer's Association, IS68. 
Goodman, W.I. and J.I. Kaufman. City Planning in the Sixties: A Restatement of Principles and Techniques. Urbana, Illinois: University of Illinois, 1965.

Higbee, E. The Squeeze. New York: Morrow Co., 1960.

Hillway, T. Introduction to Research. Boston: Houghton Mifflin Co., 1956.

Hitch, C.J. and R.N. McKean. The Economics of Defense in the Nuclear Age. Cambridge, Mass .: Harvard University Press, 1957.

Hoppenfeld, M. "The Rule of Design in City Planning." Journal of the American Institute of Planners, 26 (May 1960), 103.

Hunter, I. The Community Power Structure. New York: Double Day Anchor Books, 1963.

Jarrett, H., Ed. Environmental Quality in a Growing Economy. Baltimore: The Johns Hopkins Press, 1966.

Kennedy, R.F. Thirteen Days. New York: Norton, 1969.

Kent, T.J., Jr. The Urban General Plan. San Francisco: Chandler Publishing Co., 1964.

Klein, B.H. "The Decision-Making Problem in Development," in National Bureau of Economic Research, The Rate and Direction of Inventive Activity. Princeton, N.J.: Princeton University Press, 1962.

Kumekawa, G. "Toward the Formulation of a Regulatory Framework of Use of Narragansett Bay" (unpublished working paper, 1967), A study report to the Natural Resources Group of their study, Report on the Administration of Narragansett. Bay (Mimeograph), January 7, 1969.

Long, N.E. "The Local Community as an Ecology of Games." American Journal of Sociology (Nov. 1958), 251-60.

Mann, L.D. "Studies in Community Decision-Making." Journal of the American Institute of Planners, 30 (Feb. 1964), 47.

McHarg, I.J. Design with Nature. New York: Natural History Press, 1969.

McPartland, M. The History of East Greenwich, 1677-1960. East Greenwich: East Greenwich Free Library Association, 1960.

Meyerson, M. "Five Functions for Planning." Journal of the American Institute of Planners (Spring 1956), 158. 
Meyerson, M. and E.C. Banfield. Politics, Planning, and the Public Interest, liew York: The Free Press, 1355.

Perloff, H.S. (cd.) The fuality of the Urban Enviromment. Baltimore: The Johns Fopltins Fress, 3.569.

Providence Journal. Bulletin, Providence, R.I.

Rhoie Island Natural Resources Group. Report on Aciniristration of Narragansett Bay (rimeograph). January $7,1969$.

Rhode Island Statewide Iransportation and Iand-Use Planning Program. Medium Projection from Report No. 7. Providence, R.I.: State of Rhode Island, Dec. 1906.

Rorbolni, iv. Econonic Impact of Narrafansett Bay. Kingston, R.I.: Agriculturet Experiment Station, 1963.

Rorholm, N., H.C. Larme, N. Harshall anà J.F. Farrel]. Economic Impact of Marine-Orientel Activities: A Study of the Southern liew England Marine Rerion. Kingston, R.I.: Agricultural Eperiment Station, \#396, 1067 .

San Frencisco Pry Consorvation and Devalopmont Core saion. San Francisco Bay Plan. San Francisco: San Francisco Conservation and Development Commission, 1969.

Schickele, R. Agricultural Policy. New York: McGraw Hill, 195ir.

Simon, II.A. Administrative Behevior. New York: The Free Press, 1045.

Slavet, J.S. and M.R. Levin. Report on Administrative Organization: An Investment in Municipal Facelitence. Warwick, $R \cdot I .:$ Communty Renewal Proeram, Feb. 1565.

Today Profram. NBC News, liarch 2, 1970.

United States Bureau of the Congress. Special Census. Washington, D.C.: United States Government Printins ofice, Oci. 7, 1965.

United States Comps oi Amy Engineers. Projective Jiconomic Studies of Ner England. Waltham, Mass.: Arthur D. Little Co., lcobl.

United States Depertment: of the Navy. Stockholders Report. Irewport, R.I.: Nerport Navy Base, 1967.

Walker, R.A. The Planing Function in Uroan Government. Social science stuies 39. Chicego: University of Chicago Press, Second Edition, 1950.

Warvick City Pian Department. Faster Plan--Pccreation, Open soace, Waterfront. Warvick, R.I.: City PIan Departnent, 1004. 
APPENDIX A

PERSONAL INTERVIEW QUESTIONNA IRE 
ENVIRONMENTAL DESIGN - WEST NARRAGANSETT BAY, R.I.

PART I - Personal Interview Questions

$\times \quad$ QUES . 1

a) From this list, which of the boards and commissions do you consider have the greatest impact on the overall development policies of your city?

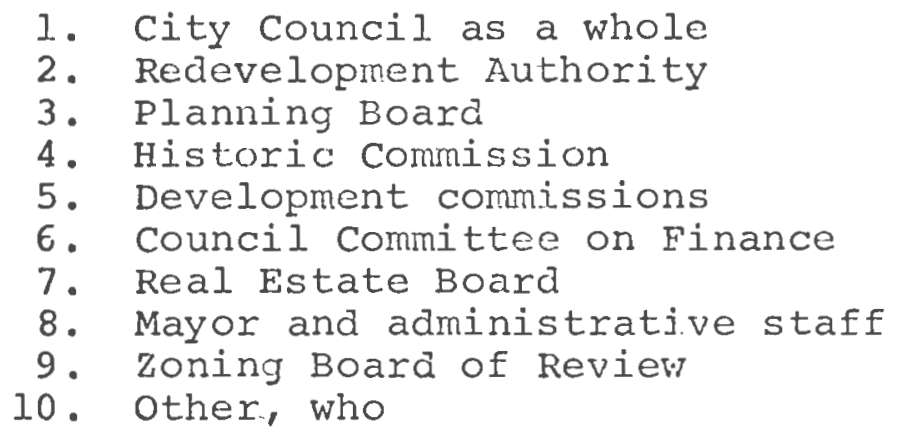

b) Can you add to this list?

c) How would you define the major emphasis of the two most important boards or commissions during the past year?

QUES. 2. Rate this list of boards and commissions for their effectiveness in handling such coastal environmental issues as open space or salt marsh usage.

QUES. 3

From this list of boards and commissions which do you consider in competition for areas of functional responsibility in planning the use of your coastal land resources?

×. QUES . 4

From this list of those not directly affiliated with local government decision making which in the past have had the most influence on public decisions relating to coastal environmental concerns, such as land use in salt marsh areas.

$\begin{array}{ll}\text { 1. realtors } & \text { 6. local foundations } \\ \text { 2. developers } & \text { 7. newspapers } \\ \text { 3. marina operators } & \text { 8. Utilities companies } \\ \text { 4. Navy } & 9 . \text { others, who } \\ \text { 5. land owners } & \end{array}$


QUES. 5 a) How is a coastal planning problem such as the reservation of open space identified and stated by your town government?

$x$ b) Which of the following groups usually initiates action:

1. Planning Board

2. Redevelopment Agency

3. area residents

4. developers
5. realtors

6. councilmen

7. city administrators

8. others, who?

$\times$ QUES. 6

From the following list indicate which types of potential coastal environmental problems receive the highest priorities in local government?

1. water pollution

2. dredging-filling

3. erosion

4. tract development unrelated to the natural landscape

5. strip commercial development

6. hurricane threat

7. industrial development

8. mass recreational use

9. other, what?

$X$ QUES. 7 a) Listed below are several alternative coastal land use classifications: which would you prefer for the section of your shore areas?

1. manufacturing

2. heavy commercial-recreational, eg. Rocky point

3. community facilities, eg. tennis, swimming, marina

4. government use - armed services

5. open space - conservation areas, eg. walking, nature walks

6. utilities

b) Why did you choose this use?

c) Under what circumstances would you substitute one of the other uses if you had the opportunity to choose any from this list?

QUES. 8

Listed below are several decision sequences, which 
most accurately portrays the manner in which the allocation of municipal money, materials, personnel, or legal protective devices were allocated when your town determined to ?
1.Citizen
Planning
City petition Board council
Council
Committee
City Council
2.Planning
Board
City
Council council Committee
City

Council

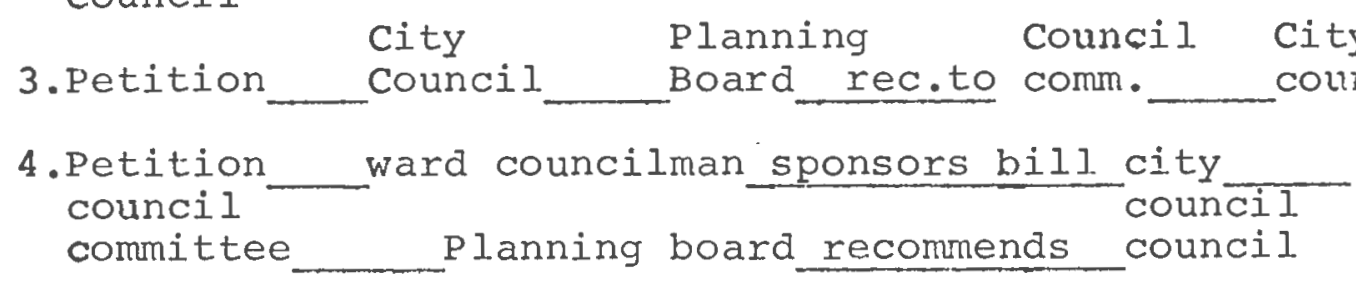

5. other, what?

$\times$ QUES. 9

Listed below is the process which could take place in making an ordinary decision in government. Assuming that all groups contributing to public decisions regarding coastal environmental use all or a combination of these elements, which combinations seem to best fit the emphasis of

(see result of ques. 1)
Planning Board

City Council council committee city administration special boards or commissions

1. Perception - obtaining of new information on coastal. situation or problem.

2. Assimilation - analyzing information in order to see the problem from several facets

3. Performance

Assessment - determines that there is a gap between present goals and activities and dimension of the probjem. 
226

4. Formulation of Alternatives - Designs a number of possible actions to close the gap

5. Analysis of alternatives - determines consequences of possible actions

6. Evaluates Alternatives - evaluates consequences of alternative actions by measuring them against goals

7. Strategy Selection - develops course of action, examines how conditions correspond to this strategy

8. Action impact \& feedback - assesses impact of action on situation, assesses new information as result of action, asseses how impact has altered the problem

9. Performance Reassessment - revaluates action in light of new information.

$\times \quad$ QUES. 10

Please rate the following in order of importance to councilmen making decisions regarding coastal land use and environmental considerations?

a) THE PROGRAM OBJECIIVE - What does the program set out to do? Are there several distinct objectives? How can they be formulated in clear and precise terms so that their degree of achievement can be observed and measured? What is their relationship to the norm established in surveying the problem situation?

b). THE ACTOR - Who enacts the program (eg., the Federal, State, or Local government? Who administers it?

c). THE PROGRAM MEASURFS (OR MEANS) - What provisions are used to meet the objectives? What are the appropriations? To what extent are the measures mandatory, or can they be accepted or rejected by individuals on a voluntary basis?

d) . THE CONDITIONS - that are the physical, technical, economic, and social conditions to which the measures are adapted and by which they are limited in their use? To what extent are the measures made flexible enough to suit 
particular conditions of various regions or groups of people?

QUES.l1 Do you feel the Council sees the Comprehensive Plan as a means of
a) directing growth
b) stimulating growth
c) maintaining the status quo
c) ignores the Comprehensive Plan

QUES.12 a) Do you feel that the present zoning in your town accurately reflects the recommendations of your city plan.

b) Is your capital budget following the needs outlined by your plan?

QUES. 13

Would you consider your Comprehensive Plan and zoning ordinance under:

a) constant significant revision

b) under small irregular change

c) fixed and well agreed upon

d) revised in reaction to circumstance

QUES . 14

$*$ QUES .15

Which of the following ways would you prefer to employ in influencing coastal land-use patterns: Please indicate which you consider to be the optimal method (most effective \& most practical)
a) zoning
b) acquisition
c) easements
d) design standards
e) special district regulations
f) other, what?

Below is a list of objectives which are commonly applied to coastal land areas. Which of these reflect most closely your coastal land use objectives in the section of your shoreline?
a). development of single use categories
b). development of multiple use categories
c). protection of existing uses
d). increased public access to coastal resources
e). preservation of natural areas
f). allocation of coastal resources equitably among all social groups

QUES.16 a) Are coastal land use objectives sufficiently defined that alternate objectives can be considered?

* b) Which of the following factors do you feel carries the most weight with decisionmakers in judging these 
objectives?

a. the official plan of the area
b. the sentiments of the residents
c. the sentiments of the property owners
d. the arguments of the developers
e. the degree in which present land uses would
be changed
f. other, what?

c) Do you feel there is a consensus among the city Council on priorities among these considerations?

QUES .17

Do you judge the advice of Federal and State agencies on such matters as open space preservation as you would information developed by local government?

* QUES.18 a) Did you determine public preferences before making coastal land allocations? If so, how?

1. public hearing

2. survey

3. by those communicating with the administration and elected officials

4. by organized citizens' groups or interests

5. other, what?

b) Did you consider these opinions representative of the majority of the affected citizens in the of your coastline?

QUES. 19

If I. had an idea to be implimented by local government concerning coastal land usage, what would be the best way to get it implimented?

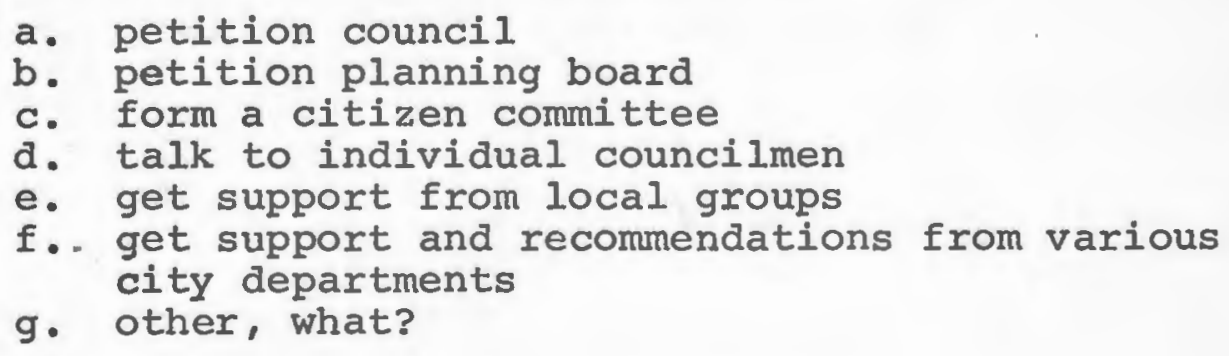


QUES.20 a) Do you feel your job title accurately reflects the major emphasis of your activites?

b) Do you feel your superiors, peers, subordinates view your job in the same way?

QUES.21 If there are conflicts present among these views do you feel that they affect the quality of information you receive and the decisions you make?

QUES . 22

To what degree do you feel the acceptance of others of your ideas toward the utilization of the section of your coastline influenced your decisions towards its use?

QUES.23 a) Do you feel the organization or procedures of your town's administrative agencies constrict new ideas for coastal environmental management?

b) Which of the following factors do you consider contribute most to inhibiting new ideas:

(1) poor outside information sources

(2) disinterest in the problems of the coastline

(3) inflexibility of present programs to innovative reorientation

(4) satisfaction with present level of program efficiency

(5) personnel restrictions

(6) budget allocations

QUES.24 To what degree do you feel new coastal management corcepts should be tested either in your town or elsewhere before a committment either legally or: financially establishes them in your town? such a concept or approach might be the acquistion of as much as coastal land as possible with leaseback privileges to the present owners.

* QUES. 25

The functions of town and state governments are increasing rapidly while at the same time government budgets are hard pressed to provide for these new 
230

demanded functions. Your state and town governments spend money on many things. Below are listed some of these things on which the governments spend their funds. Should the governments spend more money, less money, or about the same amount on each program?

program more spending less spending same spendir

1. shore erosion control

2. water pollution control

3. hurricane protection

4. beach facilities

5. land use zoning

6. road improvement

7. open space

8. marsh protection

9. land use planning

10. flood protection

11. beach creation

12. education

13. parking lots

14. harbor improvements

15. mosquito control

16. industrial parks

17. town pier

18. unemployment compensation

19. forest fire control

20. city parks

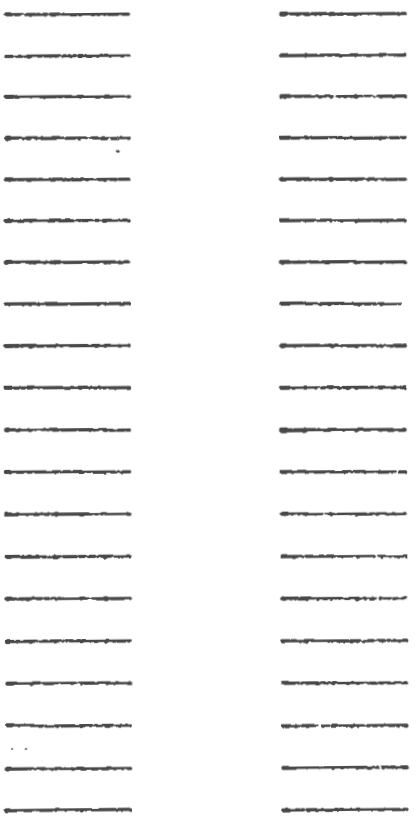

QUES. 26

For those programs above for which you said the government should spend more money, if the governments had to raise taxes to finance the additional expenditures necessary for these programs, then for which of these things would you still favor spending more money.

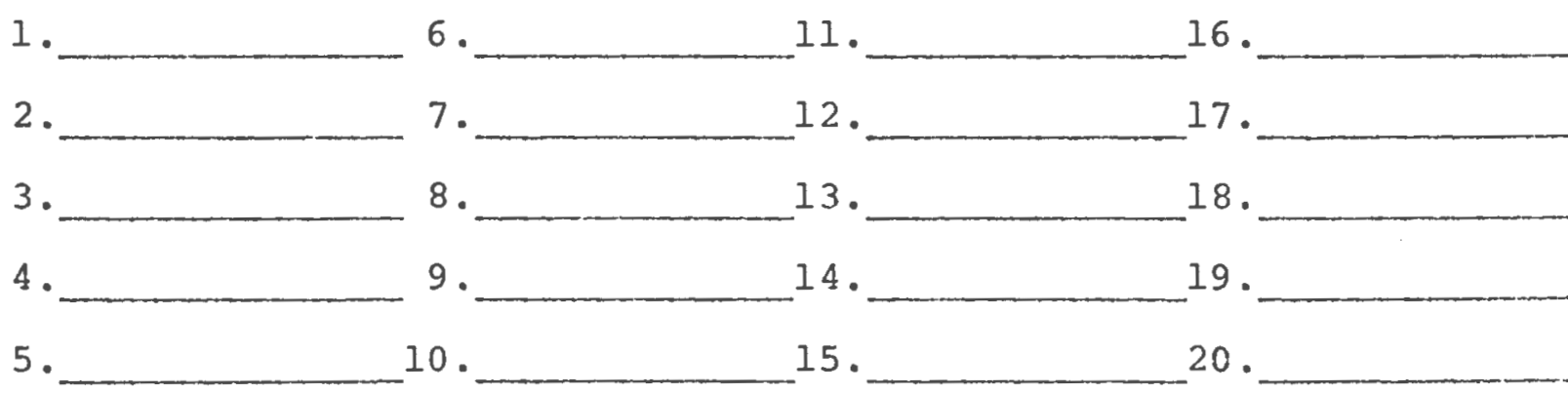

QUES . 27

If more people coming to the coast each year cost the towns and the state more money during the next few years, do you think the governments should: 


\section{1}

a. raise property tax

b. raise sales tax

c. spend less on other coastal programs

d. spend less on noncoastal programs

e. issue bonds

f. go into debt

g. begin and increase user fees for town and state beaches

QUES . 28

If you checked $3 \mathrm{c}$ and $3 \mathrm{~d}$ above, which programs suggested in number 1 above would you want reduced:

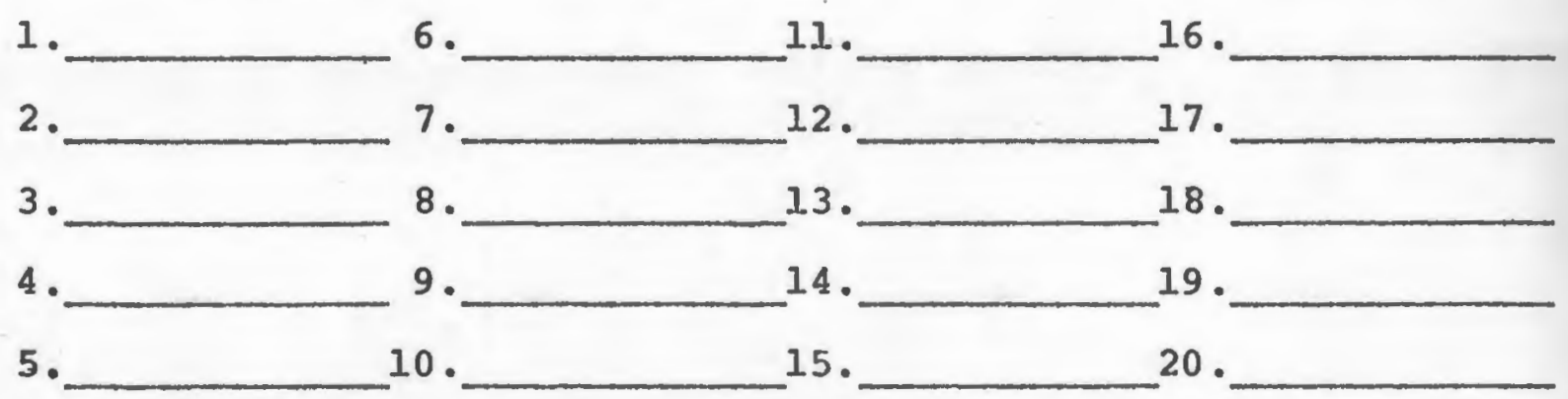

QUES.29 a) If a nuclear generating station was to be established on Rome Point in North Kingstown, what do you feel the effect would be on your town?

b) . On Narragansett Bay?

c) What of the following liabilities would concern you most, and why?

1. explosion potential

2. thermal pollution

3. change in the natural environment of the Rome Point area

4. Ecological Damage

5. change in currents

6. presence of high voltage transmission lines

7. the potential for damaging the esthetics of the area

8. other, why?

QUES.30 What is the capacity of the West Bay communities 
to absorb the following:

1. construction employment

2. operational employment

3. impact on schools, sewers, streets, recreation areas

4. housing

5. governmental supervision

QUES . 31

What is the single most important piece of information you would require before granting a permit for a land use change such as the utility request at Rome Point?

QUES . 32

What would be the effect in your town if the state passed and enforced a zoning change requiring conservation and recreational uses only of the shorelands in the future?
a) gain estimate of $\$$
b) loss estimate of $\$$
c) neutral

QUES. 33

What federal and state monies are now being used by your town which affects the coastal region? 
APPENDIX B

MAILED INTERVIEW OUESTIONNAIRE 


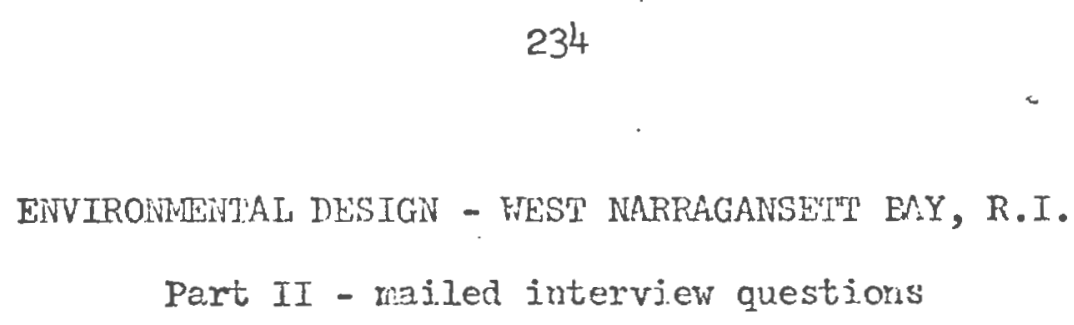

This final section of the questionnaire is designed to be completed by the intervievee and mailed in the self-addressed stamped envelope to the University of Rhode Island. None of the questions involve lengthy answers; in most cases, only a check maxk is sought. The return of the questionnaire as soon as is conveniently possible after the interview will both add to the quality of the results of this important research and be nost enpreciated by the Department of Food and Resource Fconomics at the University of Rhode Island.

Thank you for your continued cooperation! 
ENVIRONMENTAL DESIGN - WEST NARRAGANSETT BAY, R.I.

Part II - mailed interview data

Ques. 1. Age at last birthday years.

Ques. 2. Education:

a) Formal school training - circle highest grade completed:
1) grade school
2) high school
12345678
3) college
1234
4) graduate study
1234
1234
Degrees: BS BA BFA MA MS MBF MPA MCP PHD Other

b) Major at highest education level , year

c) Non college training Trade or vocational

Ques. 3. Income:

$\begin{array}{ccccc}\begin{array}{c}\$ 3999 \\ 1 \text { oss }\end{array} & \begin{array}{c}\$ 4000- \\ 5999\end{array} & \begin{array}{c}\$ 6000- \\ 7999\end{array} & \begin{array}{c}\$ 8000- \\ 9999\end{array} & \begin{array}{c}\$ 10000- \\ 11999\end{array} \\ \begin{array}{c}\$ 12000- \\ 13999\end{array} & \begin{array}{c}\$ 14000- \\ 15999\end{array} & \begin{array}{c}\$ 16000- \\ 17999\end{array} & \begin{array}{c}\$ 18000- \\ 19999\end{array} & \begin{array}{c}\$ 20000- \\ \text { and over }\end{array}\end{array}$

Ques. 4. What is your full-time occupation?

(If full-time city employee go to \#6)

Ques. 5. How many hours a week do you spend on your regular job? Attending to city business?

Ques. 6. What military, educational, work, or life experience has been most useful to you in making decisions affecting coastal land use as a public representative, official, political leader?

Ques. 7. Then was the planning function started? (year)

ques. 8. What led to the planning function being started? 


\section{6}

Ques. 9. How fast has the planning function grown since it started?

a) increase in budget from start (amount) to size now

b) increase in personnel from start to size now

c) increase in scope of operations (new functions) from to size now

Ques. 10. Of the total personnel involved in the planning function, how many are involved in mostly administrative problems?

Ques. 11. What new planning functions have been added over the last two years? (If none, check here .)
1. environmental quality
4. open space
2. water resources
3. maxine resources
5. recreational parks
6. industrial parks

Ques. 12. Do increases in budget and personnel go along with increases in planning functions within the planning agency?

Ques. 13. How broad is the scope of your planning functions?

$$
\begin{array}{ll}
\text { a) cover entire land-water area } \\
\text { check one } & \text { b) cover only land areas } \\
\text { of these } & \text { c) cover only limited land areas } \\
& \text { d) only feasibility studies } \\
\text { check one } & \text { e) comprehensive planning } \\
\text { of these } & \text { f) single function planning } \\
& \text { g) following and coordination of } \\
\text { plans of others }
\end{array}
$$

Ques. 14. Who defines the planning functions of your organization?
a) the town or city council
b) the town or city charter
c) real estate board
d) chamber of comerce
e) city manager
f) mayor
8) other, who?

Ques. 15. What town boards or commlssions and outside groups such as State organizations and other towns compete with your planning functions? 
Ques. 16. What is your system of allocating financial resources within your agency?
a) problem perception
b) pressure points
c) professional considerations
d) tradition
e) other, what?

Ques. 17. Who regularly demands the services of the planning function?
a) real estate developers
b) business
c) residential owners
d) recreation boards or agencies
e) other towns
f) conservation groups

Ques. 18. What services does the demander normaliy receive?
a) feasibility studies
b) advice
c) design services
d) other, what?

Ques. 19. From whom does the planning function derive most of its outside support in conflict situations?
a) realtors
b) business
c) newspapers
d) state
e) other planners
f) other towns
g) town council
h) boards
i) cominissions
j) other, who?

Ques. 20. How are those whom your planning function causes to sufrer handled (such as zoning changes)?

Ques. 21. What goals do you have for your planning function?

a) encourage economic growth

b) provide more life amenities

c) improvement of existing service levels 
d) arbitrate among conflicting interests

e) addjtion of neil services

f) other, what?

Ques. 22. What environmental shore protection has been done privately within your town?

Ques. 23. What is the most significant land use change along the shore during the past 3 years?

eques. 24. What significant adjustments in environmentel quality of the bay shore rave occurred in the last two yeats?

Ques. 25. What do you think is the major criphasis of the state for our Bay coast?
a) concerned with the coastal environment
b) local planning assistance
c) technical services
d) specjalized programs for coastal resource maragement

Ques. 26. Do you consider the stete planning and zoning enabling legislation adequate support for the planning activities your tom should undertake?

Ques. 27. Do you feel you have sufficient freedom to shift monies within your annval budget to meat unexpected needs?

Ques. 28. Do you undertake fund raising?

Ques. 29. What is the role of Federal grants-in-2id in supporting your korking budget? capital buaget? $\%$, in surporting your

Ques. 30. How much of your planning function is routinized? $\%$

Ques. 31. Are planning employees isolated from planning conflicts?

Ques. 32. How is recruitment for new planning employees done?

Ques. 33. Promotions within your planning functions come from within or outside ?

Ques. 34. That do you look for in a ncil plonning erployee? 
Ques. 35. What is the turnover rate of new employees in the last three years? professional , non-professional

Ques. 36. What internal training do you give new employees? If so, what do you emphasize?

Ques. 37. Listed below are some planning alternatives for directing changes in land use. Please rate each one for its effectiveness in your town. Please rate + for benefit; - for liability.

Alt. Benefit ( + ) Liability $(-)$

zoning

subdivision regulation

health regulation

building codes

land purchase

cluster development

lease

easement

eminent domain

grants-in-aid

town management

Ques. 38. To what do you contribute gaps in performance in your planning functions?
a) internal turnover
b) internal technical ability
c) low budget
d) unexpected workloads
e) change in state and federal rules
f) change in political setting
b) rapid rate of change in the community
h) slow "

Ques. 39. How do you react to public criticism of your planning solutions to coastal problems?
a) not at all
b) attempt to conform to image held
c) attempt to change image held
d) redefine functions or solutions

Ques. 40. Are there any planning functions you are willing to give up? If so, what? 
Ques. 4I. How will coastal environmental problems be resolved?
a) adoption of innovative approaches
b) kecp basic gradual approsches
c) general education of public to emenity values
d) change outside rules, e.g., enebling legisla- tion
e) other, what?

Ques. 42. On such naturel municipal boundaries as the pawtuxet River, Greenrich Cove, and Potowarnt Rivel, is there:
a) formal efiort to courdinate development policies toward these common resources
b) awareness of planning activities of abutting towns
c) no awareness of policios of neighboring towns, but willingness to cooperate in the future determinetion of new policies
d) no awareness, no interest in future coordination

Ques. 43. Which board, cormission or citizen group do you feel is most influential with the comeil or public in making decisious which relatie to coastal laind use?
1) City Council as a whole
3.0) reajtors
2) Reàcvelopment Authority
1I) developers
3) Historic Comisision
4) Historic Comnission
12) marina operators
5) Development cominjssions
13) Navy
6) Council Comittec on Finance
7) Real Estate Boara
14) land omers
8) Mayor and Aaninistrative steff
15) local founations
16) newspapers
9) Zoning Board of Revicw
17) Utilities companies
18) others, who?

Ques. 44. Which of the followinr factors most closely states your reasoning for this choice in 443 ?
a) prestige of the board, coranission or group
b) prestige of the individual memers
c) political strength
d) their technical ability in dealing with coastal concerns
e) legal authority in dealing with coastal concerns
f) their repport with decision-makcrs
g) other, what?

Ques. 45. Which best describes jour acivities in local eovermert (continued) 
241

last year: (circle answer)

a) Sought to increase your influence and personal values on original decisions and to change and increase your responsibilities within your function or area of the ortanization.

b) Sought to solve new problers presented to you through rules specifying resular operating procedures. (Sought to maintain the status quo.)

c) Sougint to promote only speciric policies you were actively intercsted in. Attempted to create in others strorig backing for your policies.

d) Sought to create a consensus vithin the rest of the organization before makjug any change in functions that affected the or canization.

e) Sought to serve the public interest as you saw it beyond your organization even if your organization would suffer.

Ques. 46. Which of the following strategies would you employ in controlling ti: cosstal environment in your tow: (circle answor)

a) Decide what you vanied to do and then attempt to do it despite obsicles.

b) Choose perheps the second best vay to control the environnent, but continue to strive for constant inprovement beyond it.

c) Gather as many facts as tima and moncy permits and seek to climinate all factors which cannot be collsidered strictly objective.

d) Deley choosing a final policy until several alternative approaches have been thorouchly tested for practicality.

e) Choose a single policy wilich from your experience or judgertent seens best.

f) Seek out and rely on others for choices.

Ques. 47. If you were asked to be chaiman of a cornittee which was to stuay and present a proersat deaing with the use of

(continued) 


\section{2}

the shoreline in your torn, which of the following professionals do you think could offer the most valuable advice. Please rate 1 , most valuable, 2 second most valuable, etc.
a) oceanograrhers
b) engineers
c) planners
d) lawyers
e) economists
f) industrial-comercial developers
g) ecologist
h) conservationists
i) othei, who?

Ques. 48. Do you feel changes in the land use patterns should occur in your town if these changes would benefit the bay area. as a whole even though accouplishing these changes would be disruptive to certain seginents of your cotmunity?
a) strongly agsee
b) agree
c) don't kno:
d) disagree
e) strongly disagree

Ques. 49. Should property oinership in the coastal area be:

held in tom commons by each constal tom held by a Bay authority held in state omership held in private oincrship with no public regulation beyond zoning held in private ormership with extended public regulation none of the above, but instead

Ques. 50.

salt marsh protection shore erosion control humicane protection land use zoning open space industrial parks aquacultural leases shoreline drives tourist complexes pier placenent rarina placenent land alteration permits

Above is listed a $f(w$ of the many programs which affect the quality of the coastal environment of liarragansett Bay. If oise administrative arency rras to he aesignated to organize and approve of these and other protrons dealing ritin the lise of tine shoreline wich of the following would you choose: 

a) a new Narragansett Bay authority
b) RI Dept. of Community Affairs
c) RI Dept. of Natural Resources
d) the RI legislature
e) the Corps of Army Engineers
f) the Federal govt. through a single agency
g) the University of RI
h) combination of the above
1) other, what?

Ques. 51. Which of the following general approaches to coastal environmental control do you favor:
a) zoning and performance standards
b) price-like devises such as deferential and preferential taxation and effluent charges
c) engineering or structural devices such as barriers, groins, etc.

Ques. 52. Which of the above do you feel is most practical administratively? Why?

Ques. 53. Here are some of the alternative ways for influencing and sometimes controlling land development. Please rank them in the order that you would prefer to see them applied in your town:

Cluster development zoning placing single family houses in circles (clusters) around dead-end roads away from the immediate shore so that greater shoreland environment is ma,intained.

Paid easements on existing property patterns to prevent future development by purchasing development rights along parts of the shoreline deemed publically necessary to retain attractiveness and maintain available space.

Condemnation with just compensation paid to owners to remove all present development along the shoreland and to re-create and attractive and open space area.

Zoning of shoreland into three zones: 1. Conservation and recreation zones on immediate shoreline; 2. Residential and developed recreation zones behind the first zone followed by the third multiple-purpose development zone. 
244

Cooperative shoreland districts designed to maintain the shoreland attractiveness whereby owmers organize themselves to accomplish the one task (such as a fire district or soil conservation district).

No pubric controls of private land use patterns and practices.

No single family homes allowed, but clustered condominium (multiple farilily) horres with large open space areas between then.

Ques. 54. Please check the box which the coastal problems stated in the vertical colum of the left can be most appropriately handle $Q$ by the one of the agencies listed on the horizontal colurm below:

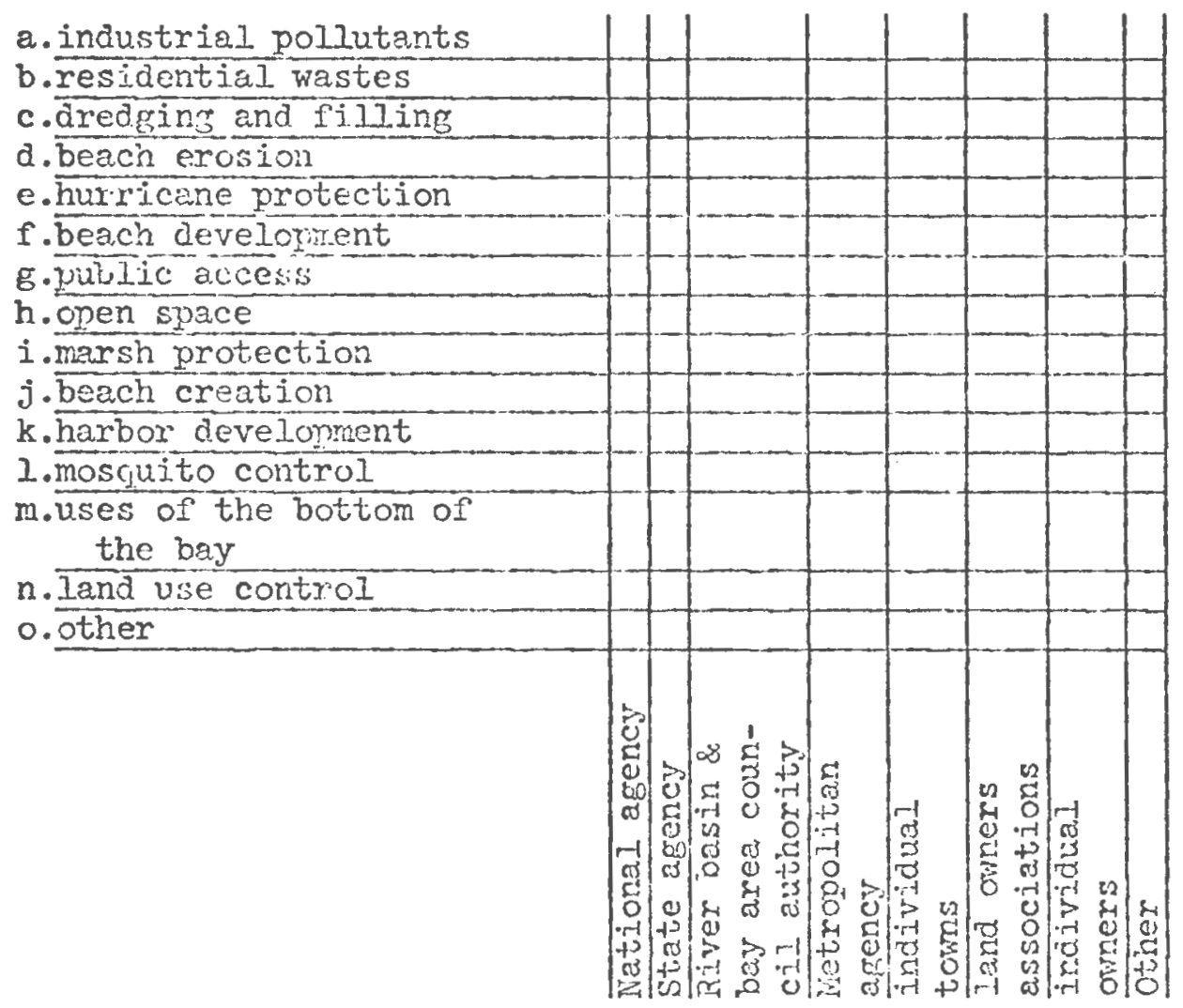


APPENDIX C

A REGIONAL CASE STUDY

COMMERCE OIL CORPORATION - A NEW REFINERY FOR JAMESTOWN 


\section{6}

Changes to the environmental quality of the Viest Narragansett Bay ocean environment may eminate from a variety of sources. Some of these changes are imperceptihle, while the impact of others is immediately clear. The folloring case presenis a story of a single development proposal whose inpact would have had regional. consequences. The real decision-makers in this instance were not located in a single municipality but instead were placed on several levels of govermment and in several provate concerns and groups. It is in this case that the impact of the passive decision factors described in Chapter II demonstrate their importance. The significance of this narrative lies not in the merits of the particular proposal in question, but rather in the potentiol it exhibited for directing the overall pattern of future developrient on the Bay. Such a potential posed questions to decision-makers which theretoforc had never been considered. This is what happened.

Comerce Oil Corporation - A New Refinery for Jamestown

During the early $1950^{\prime}$ s the cconomic condition of Rhode Island was not encouraging. Textile industries which had long been the backbone of the State's economy were declining. In 1947, 27,000 textj.le mill workers vere without employment and $11,000,000 \mathrm{sq}$. feet of mill space remained enpty. ${ }^{I}$ John $\Lambda$. Ronahan, Executive Director of the newly created R. I. Development Commission noted in 1956 in a speech on Jamestown that the state had made good industrial progress orer the

\footnotetext{
${ }^{1}$ Proviclcice jounal, May 13, $195 \%$.
} 


\section{7}

lost few years but that "we hope in the next few months to do a great deal more". In concluting tre speech Monahan stressed the importance of the Navy in bolstering the State's economy, but noted that Rhole Island was receivirg $\$ 47$ per capita of prime defense contracts while Connecticut was receiving \$620. In manufacturing Rhode Islana was receiving $\$ 307$ per manufacturing worker, Connecticut was receiving $\$ 3200 .^{2}$

Senator Pastore at the time was advocating action at both the Federal. and State level to improve the condition of the State. "Our industry in Rhode Island needs modernization," he said. "Many of our plants are archaic. Industry has taken the position, at times, that it has done enough to nodernize. Laboi has sondines taken the position that not enough profits have been plowed back in to industry to modernize." ${ }^{3}$ In forming the Development Council. in 1951 Governor Roberts had made his major political thrust around the issue of economic development for the state.

During 1953 and 1954 Lehman Brothers, New York financiers, in conjunction with Gulf Oil Corporation created Comercial Oil Company which sought to build a refinery first in Portsmouth and then in Janestown. The Corporation came into existance because Gulf Corporation sought an east coast refinery to which they could transport kuwait crude oil and from which they could ship the processed oil to transfer points. The land originally acquired by Comierce, Jocated on the north-

$$
{ }^{2} \text { Ibid. }
$$


$2 ! 8$

ern end of the Jamestown Island and stretching along both the East and Vest shores, was sparsely settled with sunzier and permanent homes. Before the refinery could be built, however, several important hurdles had to be crossed. The acquisition of additional land was necessary both in Jarsestown ana North Kingstown. Local zoning restrictions had to be overcome. Navigation clearances from the Navy were required as well as from the Corps of Army Engineers. A large fresh vater surply also had to be obtained for the operation of the refinery.

By September 27, 1956, the Jamestown Town Council had passed a zoning ameridment creating a refincry use district which included over 16,000 feet of shoreline on the east and vest coastlines and included over 640 acres in the interior of the island. Councilman Francis $K$. Costani and Town Solicitor Daniel Murxay vocally supported the establishment of the $\$ 55,000,000$ refinery on the erounds that it vould prove to be an immense tax producing resource for the town which had no industrial base and would serve as an employer of. 250 area residents. Public opinion at this time had not become polarized for or aceinst the proposed refinery, yet all vere aware of the tox benefits it offered the torm.

During this period, however, several of the residents whose properties were being scught by the Comnerce to enlarge their site and others in the immediate area became alamed at tho implications a development of this scale and nature would have on the character of the Tow and the Bay area. Forming the Jamestom Protective Association with an initial menuership of 17 remere, area resident Dr. Wijliam ". Miner sought the support of the Navy, President Bisenhorner, and the 
State Division of Rivers and Harbors in preventing Comerce from proceding with the construction of a concrete pier which was to extend 850' into the Fast passage of Narragansett bay then run 1205' parallel to the shore.

Up to January 1957, the forces gathering on both sides of the issue remained locally based. Each sought to win the support of the Navy for their own point of view. The Navy's Department of Defense Mobilization had the authority to approve or disapprove of the extension of the rapid tax write-off cextjficate which vas essential to Lehman and Gulf's financing plans. The State up to this time remained reticent on the issue althourh Governor Roberts was known to be working for the establishment of refirery as was Development Council Djrector, Monahan. Before Connerce could proceed in any meaningful way with the actual. construction the pier had to be built with the approval. of the State Division of Rivers and Harbors with subsequert exproval of the Navy and Corps of Arry Engineers. On January 9, 1957, the Director of the State Division of Rivers and Harbors announced that a public hearing rould be held on January 22. The relcased statement, said:

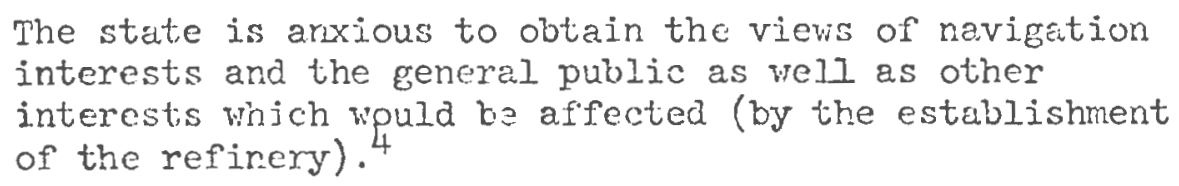

The Jamestown Protective Assocjatior, whose nembers had quickly swelled to over 700 had not been idle during this poriod and had, as a result, been instrumental in forming the west shore Assocjation composed of

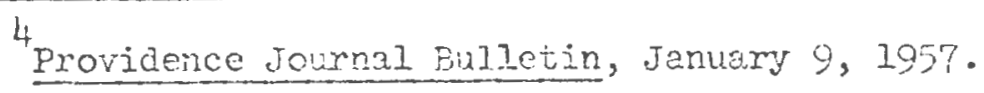


over 200 members from North Kingstown, East Greenwich, South Kingstown, and Narragansett. On February 15 th a Journal Bulletin editorial urged the creation of a panel of experts from the University of Rhode Island and from industry to try to answer some of the following questions.

1. Is the Comerce Oil refinery a threat to the Bay resolirces?

2. How would such an installation affect the Navy?

3. What is the balance between the immediate economic gain orfered by the refinery and the long term sucial benefits the Bay itself offers in its undeveloped state?5

Within a week, State Senator Joseph Savage co-sponsored a bill before the Rhode Island Lerislature which would create a Senate subcomittee to investigate the economic impact of the Jamestom Refinery.

During the last two weeks in January 1957 several key develonnent:s took place. Navy Undersecretary Thomas S. Gaties, Jr., had announced to Commerce Oil's latyers in Washington that the Navy would "prefor that the refinery be located elsewhere" and that the use of the plannea site might force "adjustments in the Navy's operations which could affect military readiness." 6 The Newport City Council backing the Navy voted to oppose the refinery location. The Corps of Army Engineers in separate deliberations had approved phases of the refinery plan under its jurisdiction after conferences with the Company and public hearings.

Comerce oil Company began the second round of negotiations with the Navy in Washington and finally managed to overcome every explicit objection of the ravy. This included a plan to relocate the proposed

\footnotetext{
5 Providence Journal Bnlietin, February 1.5, 1957.

6 Providence Jouinal Bulletin, October 11, 1957.
} 
pier Irom the Viest to the East Passage of the Bay, and the resiting of other facilities the Navy feared vould interfere with aviation controls. After this second round of meetings Undersecretary Gates wrote,

"We have urged the Company to give full consideration to the needs of national defense in making their rinal determination as to the site of the proposed refinery. We only hope that they will select some other location and not reduce the value of Narragansett Boy as one of the Navy's three principal opcrating bases."7

What the Navy com whose reconmendations had a major effect on the financial arrangement of backers of Commerce 0 i. was not public record. It was clear from the ravy's statements however that Narragansett Bay's deepwater channel that had originally attracted the Navy to establish the Nerport and Guonset Point llavy bases was also an important factor in Commerce Oil's intentions to locate in the Bay Ared. No other Bay in the New England Region offered the site potential. for such a refinery supported by tankers in the $1.00,000$ ton scale.

North Kingstom, feeling the pressure excrted by the West Bay Association, began to assess its position toward the refinery. It was the intention of Comerce Oil who had already spent several hundred thousand dollars in acquiring property on Jamestown and in North Kingstom to sink wclls in North Kingstom to supply the refinery with the required 2 miltion gallons a day for use in the refining process. The location of the proposed well sites near the manicipal wells promoted the rom Council to direct the Town Solicitor to take steps to insure and protect the Town's water rights.

$7_{\text {Ibid. }}$ 
252

While opoosition appeared to be growing in every quarter proponents were beconjine more active. On the state level Governor Roberts and State Developrent Director Monahan were speaking out for the installation of the facility while locally the Janestown Tom Council sought resident support. A meeting sponsored by the Commerce and Gulf oil Corporations was held at the Barrington Yacht Club for members representing yacht clubs and marinas across the state to explain the effects the refinery would have on yachtsnien.

Extensive oil spillage from a Sinclair Oil Company tanker off Nerport in 1952 had aroused much concern among yachtsmen in the Bay area who witnessed the lengthy conflict between the City of Newport and the Sinclair Co. over the cost of boating and besch dencises.

During the winter of 1957 Comerce Oil extensively circulated brochures describing modern refinery methods and how through mojern design refinery facilities could be attractively integrated into the landscape. Nevertheless, in Fetriary the report of the Governor's Advisory Comission set up to study the situation concluded,

"The existence of a refinery at Jamestom would be incorpatible with Naval operations in the Bay." 8

This statement focused the issue again around the economic importance of the Navy to the state leaving issues of environnental concern as a secondary consideration.

Shortly after the report of the Governor's Cornittee was issued, the Journal Bulletin editorial entitled, "On Balance, a Rerinery on

${ }^{8}$ Providence Journal Buljetin, March 9, 1.957. 
Jamestown looks good for Rhode Island." The paper stated that it would not support the construction of the refinery if they believed the plant would be a real, present and perpetual danger to the Bay everyone wanted to piotect. Citing the danger of fire and explosion, noise, smoke, particulate matter, toxic and noxious gases, odorous materials, glare and vibration, the paper ureed rigorous standards be applicd in Janiestorm. 9

Governor Roverts had made a passing reference to enacting air and water poljution controls in the state Legislature and promised to shut the refinery down if it did not conform after it was built. Secretery of State rotte who had been a proponent of the refincry more candidly told fishesmen at a meeing of the Bristol. County Shellf'ish Association that he had "visited the refinery area" and that from first hand experience he was convinced that no safeguards were able to cure the nuisance--actual, not potential-- of the refincry. ${ }^{10}$ Anthony Del sesto, Planning Director of Cranston, was quoted as saying that the State needed new industry, that the refinery vas an indusiry but adied that for this type of industry an appropriate site should be sought elsewhere than on Jamestown. The Jamestorn Council had enacted no ordinance up to this time imposing any performance standards on the proposed refinery. Within the next 6 months Comercial. Oil Corporation began to push more aggressively in secking a resolution of the issue on the local level. On March 12, 1958, the controversy moved to the courts when

9providence Journal Bulletin, larch 31, 1957.

$10_{\text {Ibid. }}$ 
Commercial 0il. Comporation filed suit for $\$ 3^{t}, 000,000$ in U.S. Distrjet Court against the original 17 meribers of the Jamestown Protective Association charcing them with conspiring to block the refinery. Among the attorneys for the pleintiff was Daniel Murray, Town Solicitor for Jamestown. Later the suit against the landomers was dropped but a counter-claim for the defenciants seeking an injunction to stop the refinery was pressed forward by the Protective Association under the legal advice of attorneys Moor,, Virgarlaino, Boyle and Lynch of Newport. Commerce oil continued their public relations efforts by purchasing a full pare advertisement in the Sunday, March 9th Providence Journal with a general aerial view of the proposed refinery and an architect's rendering of the facility which included, in addition to the refinery equipment, an athletic field house, a swimming pool, two bascball diamonds and tennis and badminton courts.

The federal suit which extended through 41 days of court hearing, 19 days to present the Association's case and 22 days to present the refinery's case was finally resolved with a decisjon which was 5 montins in preparation handed down by Judge Edward $\mathrm{W}$. Day.

"I an satisfied," Judge Day ruled, "that the operation of the said refinery in the manner and at the location proposed by the plaintiff (Comerce $0 i l$ ) would cause a substantial diminution both in the values of the derendant's properties and in their enjoyment thereof', as measured by the degree of comfort the average man liviner in such a locality has the right to expect.

It follows that said use will be unreasoneible and hence a nuisance to the defendants (the Jumestown protective Assosiation) against wich they are entilled to injunctive rejief."Il

Il Providence Journal. Bulletin, Jauuary 9, 1959. 
Regarding the threat to the environment of the town the Judge ruled in his 33 page decision that:

". The credible testimony in this case establishes that said gases (from the operation of the refinery) will be carried by prevailine winds at a.lI tines to the properties of some of the defendants, and, because of their extremely disagreeable odors in very low concentrations and their cumulative effect, they will seriously diminish both the value of the derendant's land as residential properties and there enjoynent thereof." 12

In ruling that the ccmerce refinery would be a nuiscince Judge

Day waid that the fact that it may be useful or may contribute to the welfare of Jamestom was not legally at issue in the case. The zoning anendrent creating a refinery use district voted by the Town Council on Septenber 27, 1956, vas caste as invalid.

"It is a matter of common knowledge that an oil refinery is a potential source of danger from fire and explosion unless properly constructed. And it is similarly a matter of comon knowledse that such a danger from fire and explosion can be substantially lessoned if not entirely eliminated by tho imposjtion of proper restrictions and safeguards relating to its construction. The record in this case is completely devoid of any evidence that could possibly support the finding that sajd amendment to the bujlding ordinance is conducive to the conservation of public health, safety or welfare of said tom."13

Regarding the license granted Commerce by the Town Council Judge Day said that the ordinance under which it was granted was illegal because it was not in sirict conformity with the General Assenbly Enabling Act that provided for the torin ordinance.

He ruled that the ordinance did not provide the strict control

12 Ibid.

1.3 Ibid. 
over the refinery operations specified by the statute. Instead the Council incorporated in its ordinance only "by reference" standards described by such organizations as the National Board of Fire Underwriters .

Harold M. Geller, the Executive Vice President of Commerce said, "We definitely are going to appeal." In the appeal procedings Comerce Oil.fortunes took an upturn when on June 16, 1960, the U.S. District Court of Appeals reversed the restraining order against construction and unanimously denied petition for a rehearing. Attorneys for the Jamestow Protective Association made statements that they were considering taking the case to the supreme court. ${ }^{14}$

While at least some of the legal recourses were being resolved for Commerce Oil the ground swell of local opposition was gaining new support throughout the West Bay region. The Narragansett Bay Homeowners Association had formed consolidating many of the mainland groups which separately had-opposed the refinery. Association President Lewis G. Calvani of the Newport Chamber of Commerce noted that in December 1958,

"Very few people are willing to risk capital in investment in the area (Narragansett Bay Area) before knowing whether Narragansett Bay will become a major site of the oil refining industry with the subsequent annihilation of its present character. Capital investment would be spurred and initiative released if the oil refinery industry is excluded from the bay. Exclusion of the industry would be a clear demonstration that the state intends to protect its greatest natural resources." 15

In urging stronger support in their fight Calvani noted that the Association budget had dropped from over $\$ 56,000$ to less than $\$ 1,000$ and that

\footnotetext{
${ }^{14}$ Providence Journal Bulletin, January 5, 1959.

15 Providence Journal Bulletin, December 6, 1958.
} 
the backers of the refinery had already spent over \$I milition.

In December 1960 , after over seven years of coniroversy Commerce Oil Corporation had still to resolve the difficult restrictions placed on the refinery construction as a condition of approval by the Navy; had not received the rapja tax write-off certificate from the office of Defense Mobilization; faced continuëd court entanglements with the Jamestown Protcotive Association, and was losing the active support of State political leaders who were feeling the pressure of public sentiment against the refinery proposals. In addition Demosratic Senatorial Candidate Claiborne Pel.t. has stated,

"I've weighed it carciully in my mind. As I see the picture, the refinery is objectionable in puricular to the vavy. In totio, I would be inclinst to bal jeve there should not be a refinery on the Island of Jamestom."lo

During this period Commere oil comoletely stopped their efforts to establish the refinery. Norbers of the Rhoie Island Development Council. who were activcly particinating in the issue resolution believe that the logal and political implications of the refinery controversy forced financial backers of the proposal to withciraw their support for the refinery .

Francis R. Costani, Acting City Council President of Janestown, reflected in his renarks to Tom Council in 1959 the dismay and distrust he felt in the final outcome of the issue. He stated that he felt that a wealthy minority of out-of-town people had managed to overrule a workers najority. In reading a colum written by Irew Pearson

\footnotetext{
${ }^{16}$ Providence Journal Bulletin, Norember 7., 1960.
} 
before the Council he said that it was necessary to inform the people of Jamestown,

"So that they will be able to defend themselves against outside intruders, many of whom are in high places. Much of the opposition to the refinery was in the dark and for that reason I think the Council should make public any information that comes to its attention."17

No such information has yet turned up.

But while there was no evidence that outside "intruders" directly influenced public officials, it is interesting to note that interviews with both attorneys for Commerce Oil and the Jamestown Protective Association stated that the case which is the longest on record in the State's history tied up the majority of their respective legal staffs for more than a year prior to and during the final court presentation. While Comerce Oil Corporation could afford such an outlay it is difficult to see how the Protective Association which had no formal resources could sustain such services without substantial financial backing. People closely associated with the case during this period on both sides of the issue unanimously felt or speculated that this support which althouth it lost the legal battle ultimately won the environmental war was supplied in generous measure by philanthropist Doris Duke of Newport. Attorneys for the Protective Association, Moore, Virgadamo, Boyle and Lynch of Newport declined to speculate on this question. The Planning Factor

Bven though the Rhode Island Developinent Council's mandate was to encourage economic development, interviews with staff members participat-

${ }^{17}$ Providence Journal Bulletin, January 27, 1959. 
ing in this issue indicated that no effort was made on the part of that state agency to analyze the potential impace of the refinery on the Bay or Bay area communities. At that time Cranston and Warwick had planning departments but they played no apparent role in influencing the State govornment's posicion supporting the plan. Neither the state or local governments had the technical resources available to effectively determine objectively what the inpact of this facility might be both ecollomically or ecologically. The University of Rhode Island also had. no formal mechanism for organizing this information.

organizationally there was no mechanism for relating the local concerns brought about by the externalities of this proposed development to the supposed benefits this refinery would bring to the region. As a result each jurisdiction and citizen's group actea independently through various institutions such as local Eovernment, while Commerce Oil could maxirize its organizational capabilitios and actually plen o develoment strategy for gaining the public sanctions required. Their highly organized institutional form, embodied in the rodern corporation gave them an advantage over the high ly fragmented positions taken by opponents. There vas no institutional structure representing the public which could counteract the viewpoints expressed by this industry. There vas no agency capable of answering the question posed by the editorial writer on the Journal Bulletin, "Winat is the balance between the immediate economic gain offered by the refinery and the long term social benefits the pay offers in its undeveloped state?" Ultimately it was the Navy that denonstrated the strength to overcome the compuny's position. Local, state and regional concerns for the type of develop- 
ment precedent this refinery embodied had no mechanism for expression. Planning did not interact as a factor in this issue resolution. The Political Factor

The political factor had an uneven impact on this issue resolution. Governor Roberts sought to strengthen his position by supporting economic development of the state at the risk of greatly depleting the quality of the State's major natural resource. The heads of administrative agencys charged with overseeing the use of this resource followed his lead.

The many positions taken for and against the proposal had the effect of keeping elected state legislative officials from actively participating in the interaction between the corporation and the public. It was not until groups joined ranks that a clear position became evident for legislative decision-makers. At this point they moved toward stopping the proposal.

Citizen opinion against the proposal embodied in the Jamestown Protective Association proved to be the major political force blocking the refinery. They were able to both delay construction of the refinery and also swing public opinion against the proposal. This small group unencumbered by an official organization was able to forcefully express their views against the proposal. No other political organization was able to do this without alienating some of its supporters. One might hypothesize that traditional political institutions on the State and local level are ill-equipped to deal with radical large scale development proposals when public opinion is unclearly expressed. On another level, politics may have played the deciding role in 
261

this issue resolution. Extensive inquiries failed to determine on the national level why the Navy did not grant the rapid tax write-off certificate. Whether oil lobbies influenced the Republican administration on this issue is unclear. It was on this point that the issue resolution revolved. Local political sentiment appeared to bear little impact on the Navy's decision. Indeed, in the final analysis, the relationship between Commerce Oil Corporation and the Navy Department was of greater import than the local relationship between the potential environmental polluter and the local environmental users. The Market Factor

There was only one significant reason why Commerce oil Corporation sought to locate on Narragansett Bay. The location of the Bay and its deep water channels provided a resource the company could not find elsewhere. This aspect of the Bay made it in great demand for this specialized use. In this case it was not cormeting demand but scarcity of this resource characteristic that made the purchase price for access to this resource one investment on which Conmerce oil would not quibble. When local landowners resisted for political reasons the market pressures to sell out the Corporation sought to have the courts sanction their market influence which in this case they created.

On a state-wide basis the creation of added jobs and tax revenues greatly influenced the decision-makers in Jamestown as well as on the state level. The market factor can be assessed as the primary reason the company received state and local support. It did not seem to make a great impact on regional functionally oriented groups such as yacht or fishing clubs or on such local governments as Newport or North Kings- 
town whose concerns were expressed because of fear of economic and environmental depletion in their respective towns due to the competition the refinery posed. In Newport the Council felt the refinery tankers would hinder the Navy, thus making Newport less desirable as a base. This base is the major source of economic stability for the City. In North Kingstown the refinery was viewed as competitive with the town's ground water resources. Being the closest adjacent municipality, the town viewed the economic impact of the refinery as potentially costing the town money by depleting its water resources without adding to the town's tax base. It appears however from subsequent interviews that environmental concerns are of lesser importance than the potential for increased tax revenues when, in a different case, the economic benefits accrue to North Kingstown (see Appendix D). The market factor played a critical role in shaping the thinking and actions of almost all the participants in this case. Only the Jamestown Protective Association and other citizen groups argued against the issue on grounds other than those dealing with economic concerns. The Economic-Ecologic Dichotomy

Neither local, state or Federal governments or their agents represented the ecologic viewpoint in this issue; nor was there any institutionalized voice capable of doing so. The particular Bay resource characteristic of depth attracted Comerce 0il to the Bay and yet no action was taken to preserve environmental qualities of the other Bay characteristics. Only the Jamestown Protective Association advocated environmental considerations. They were supported by individual contributions by people whose personal values reflected this 
organization's position. While they were required to take a defensive position against the advocates of the market factor by using citizens groups to pressure elected officials and by using courts, they were unable to coerce state or local jurisdictions to seriously consider environmental concerns. This case strongly demonstrates why this dichotomy exists and how, as a factor in the decision-field, this factor is a passive consideration. The ecologic viewpoint is more a way of thinking and a reflection of personal values than a definable method of operation generating immediate fiscal returns. Jurisdictions and Controls

The diversity of jurisdictions and controls had a significant impact on Conmerce 0il's plans to construct a refinery. It appears they had the greatest effect in negating the company's plans on the lowest and highest levels. Both local landowners and the Navy proved the most difficult jurisdictions from which the company required sanctions. There appears to have been no communication among the administrators of these jurisdictions and controls. Hence Comerce presented different aspects of their proposals to those jurisdictions and controls which can be described as holding the middle area. An example of these would be the State Division of Rivers and Harbors, the Corps of Army Engineers and the local government of Jamestown. Each viewed the proposal from their own jurisdictional point of view with Jamestown seeing the proposal from almost an entirely economic viewpoint.

It appears only local landowners and the Navy viewed the proposal as a whole. Both rejected it. 
APPENDIX D

THE ROME POINT POWER PIANT - BENEFIT OR LIABILITY 


\section{5}

The following narrative describes the setting for a major environmental issue which will arise in the next ten years. The decisionmakers interviewed all will probably play an important role in its resolution. Ecologically and economically this issue bears a close resemblance to the refinery case in Appendix C. The purpose of presenting this case is to document the fact that future large scale development proposals will be placed before local decision-makers which have a regional impact. Who will have the authority to resolve such issues and how will local and regional development objectives be reconciled?

The Rome Point Power Plant - Benefit or Iiability

In September, 1953, the Narragansett Electric Company bought 98 acres of sloping woodland abutting Rome Point in North Kingstown. The parcel, located approximately $1 / 3$ of a mile north of the Jamestown Bridge, is bound on the west by Boston Neck Road (Coastal Rt. 8) the inland access point; and on the north and south by large undeveloped parcels of woodland owned by individuals, one of whom is currently a member of the North Kingstown Town Council (but was not at the time of the acquisition). The eastern boundary of the property has approximately a two hundred foot frontage on Narragansett Bay.

Though the property was acquired over 17 years ago, the surrounding area remains the least developed of any section of the coastal environment within the study area. The current North Kingstown Planning Board Chairman and other.decision-makers feel this general section of the coastline will remain in this state because of the difficulty in 
sewering the area and the ineffectiveness of septic systems in handling anything but light charges of effluent. The nearest dwelling to the site is approximately one half mile. Developers owning property which shared similar soil characteristics located immediately south of the Jamestown Bridge were required by these same decision-makers to recognize this consideration and increase their lot sizes from a twenty to fifty thousand square foot minimum. Currently the Rome Point site is zoned for single residential development with a twenty thousand square foot minimum lot size.

At the same period during 1951 and 1952 when Lehman Brothers of New York created Commerce Oil Corporation, Narragansett Electric Company felt it would be prudent to purchase an additional generating site on Narragansett Bay which could be put into use as a fossil fuel or nuclear power generating plant as the future demand on the company demanded. It was felt by company officials that a site in the south County region would be advantageous because of its proximity to existing service areas, areas to the north in the Providence SMSA, and sources of potential growth to the south which include the University of Rhode Island and the Southern Rhode.Island-Eastern Connecticut land areas. Company officials report that the selection and acquisition of the site was made on criteria of availability and least cost and was completely independent of and without knowledge of the potential relationship to the proposed commercial oil refinery to be located on Jamestown directly across the West Passage of Narragansett Bay, a distance of less than one mile from the North Kingstown site. 
constructing any type of station on this site. Indeed, they are moving very cautiously in this direction. As part of the "Big 11 Power Loop", a New England network of electrical power plants, Narragansett Electric Company has recognized the future economies and desirability of establishing nuclear power generating stations. They appear equally aware of the intense public concern over questions of ecological damage and thermal pollution potential which have focused national attention on such rural areas as Vernon, Vermont, where a nuclear station has been constructed on the Connecticut River. A major fossil fuel generating station of the Company located on the Providence waterfront is a heavy contributor to the State capitol's air pollution problems. In a recent front page series of articles on this subject in the Providence Journal Bulletin, the State Director of Air Pollution Control stated that Narragansett Electric Company was the state's number one source of air pollution. ${ }^{1 .}$

Prior to this series and cogniscent of the Commerce 0il controversy, Narragansett Electric Company contracted with the University of Rhode Island to gather all physical and biological data on this land and on the West Narragansett Bay passage that would be needed to undertake the necessary research before establishing any type of generating facility at the proposed location. Under a separate research grant from the Department of the Interior and endorsed by the company, the University of Rhode Island is seeking to determine uses for the heated water that would be discharged from a nuclear plant at this location. Such

\footnotetext{
'Providence Journal Bulletin, January 14, 1970, p. 1.
} 
potential uses which might bonefit from the application of this water are recognized as being:

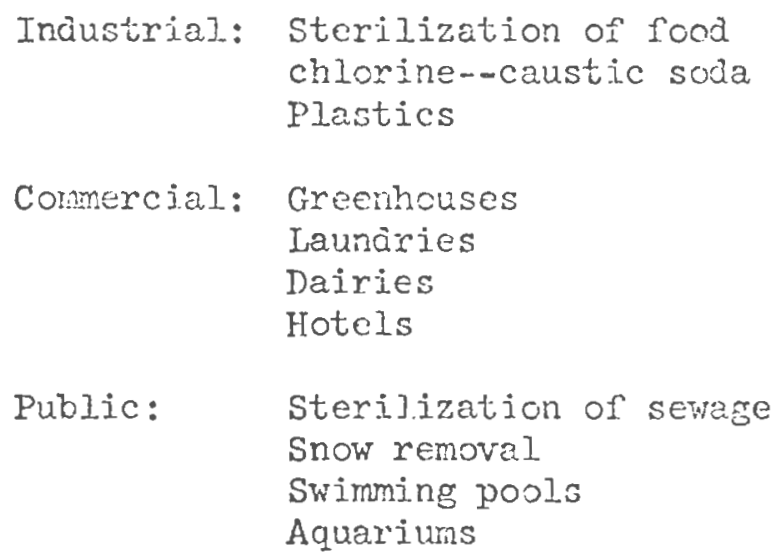

A principal investigator on this project, Dr. Vincent Rose, Assistant Professor of Nuclear and Ocean Fngineering of the College of Engincering at the liniversity of Rhode Island, estinated that because of the complexity of such an engjneering and desien proposal as vell as the time span inherent to compliance with and approval of federal regulatjons and licenses that any facility projectiea on sitie could not be expected to be in operation much before 1980 .

It is impossible to estimate the potential impact of such a nuclear facility on North Kingstown or the Narragansett Bay coastal environment, ten years hence should it be built. Based on current trends in the electric industry, however, $\mathrm{Dr}$. Rose estimates that, such a facility would, if completed today, probably be in the 1000 megawatt scale, slightly larger than the nuclcor plent located at Haddom Neck, Connecticut, and would cost in the range of $\$ 230-270 \mathrm{milli}$. Should cooling torers be required as was the case in Vernon, vermont, \$25 million would be addal for esch torer.

Based on this estimate the folloning computation might be used as 
a general guideline to the financial impact the Rors point station might have on Norih Kingstown based or the current tax rate of $\$ 33.50$ per $\$ 1,000$ assessment using a $100 \%$ evillation for the base year of 1961 .

$$
\begin{array}{lll}
\text { Land (98 acres) } & \text { Valuation } & \text { Annual Tax } \\
\text { Rome Point Power Station } & \$ 1122,500 & \$ 4,103.75 \\
(1 \text { cooling tower) } & \$ 275,000,000 & \$ 921,250.00 \\
& \$ 275,122,500 & \$ 925,353.75
\end{array}
$$

The current assessed valuation of North kingstown real estate is $\$ 82,300,000$. Total tax receipts for the tom this yax year amounted to $\$ 3,051,089.3$ Applying these rigures as reierence point, one can see that the impact of such a generating station in North ringstown would, in tems of tax dollars, increase real tax revenues by $30 \%$ if it wore completed toảey.

EiEllteen key decision-makers in the study area were personal.ly intervieved and asked the following questions as a basis for discussions (Appendix A, Q. 29-3l).

1. (A) If a nuclear generating station was to be establishea on kome Point in North Kingstown, what do you feel the effect rould be on your town?

(B) On Varragansett Bay?

(c) What of the following liebilities would concern you most, and why?

1. Exnlosion potential

2. Thermal pollution

${ }^{2}$ Office of the Assessor, Norin Kingstom, R.I., 1/24/70.

3 Orfice of the Assessor, North ringstom, R.I., I/24/70. 
3. Change in the natural environment of the Rome Point Area.

4. Ecological damage

5. Change in currents

6. Presence of high voltage transmission lines

7. The potential for damaing the aesthetics of the area

8. other, why

2. What is the capacity of the West Bay Communities to absorb the following:

1. Construction employment

2. Operational employment

3. Inpact on schools, sewers, streets, and recreational needs

4. Housing

5. Governmental supervision

3. What is the single most important piece of information you would require before granting a permit for a land-use change such as the utility request at Rome Point?

North Kingstown - The General Consensus

The four decision-makers in the North Kingstown government from the town council, town administration, the Planning Board and the Conservation Commission all felt strongly that the tax benefits to the town would be the most significant impact of the supposed station on the town. Only one individual in the four felt the plant might have any effect on Narragansett Bay, though thermal pollution and high voltage transmission lines were viewed as liabilities. No decisionmaker in North Kingstown or the three other communities felt the presence of the plant would have any significant effect on the communities capacity to absorb construction employment, etc. (0.2). All felt pollution was the major aspect about which they would seek additional information. 


\section{Cities and Torms}

The Cities of Cranston and Warwick expressed strong negative attitudes toward the plant both of the effect it would have on their cities and on the Bay. The related themes of thermal pollution and ecological damage were viewed as the major threats to the Bay and hence to these communities. The majority of those interviewed in these cities, especially those non-elected members of boards or from their respective administrations expressed the view that the plant should be seen as a potentially harmful development and further that the company should be expected to furnish complete information on all aspects of the operation affecting the coastal environment. Warwick Planning Director felt further that such a. development like a nuclear station or an oil refinery would establish a scale and style of development which might permanently change the contemporary residential development patterns of the West Narragansett Bay coastal environment.

The Towns of North Kingstown and East Greenwich expressed no or mild concern over the potentially harmful effects of such a plant. These concerns were articulated in terms of engineering and safety precautions such as Atomic Energy Commission Reports and provisions for performance or maintenance guarantees rather than ecological concerns.

Those that expressed the strongest negative opinions shared either a professional training in the areas of conservation and ecology or regularly used the Bay for recreation purposes.

Conservation Commission Members interviewed held no or mildly negative opinions toward the establishment of the plant. 